\title{
Barrier Island Groundwater Dynamics
}

by

\author{
Rachel Mary Housego
}

B.S. Environmental Science, B.A. Mathematics

University of North Carolina at Chapel Hill (2014)

Submitted to the Department of Civil and Environmental Engineering in partial fulfillment of the requirements for the degree of

Doctor of Philosophy in Oceanographic Engineering

at the

MASSACHUSETTS INSTITUTE OF TECHNOLOGY

and the

WOODS HOLE OCEANOGRAPHIC INSTITUTION

June 2021

(C2021 Rachel Mary Housego. All rights reserved

The author hereby grants to MIT and WHOI permission to reproduce and to distribute publicly paper and electronic copies of this thesis document in whole or in part in any medium now known or hereafter created

Author

Joint Program in Oceanography/Applied Ocean Science \& Engineering

Massachusetts Institute of Technology

\& Woods Hole Oceanographic Institution

Department of Civil and Environmental Engineering

May $6^{\text {th }} 2021$

Certified by

Britt Raubenheimer

Senior Scientist, Applied Ocean Science and Engineering

Woods Hole Oceanographic Institution

Thesis Supervisor

Accepted by

Colette L. Heald

Professor of Civil and Environmental Engineering Chair, Graduate Program Committee

Accepted by

David Ralston

Associate Scientist, Applied Ocean Science and Engineering

Woods Hole Oceanographic Institution

Chair, Joint Committee for Applied Ocean Physics and Engineering 


\title{
Barrier Island Groundwater Dynamics
}

\author{
by \\ Rachel Mary Housego \\ Submitted to the Department of Civil and Environmental Engineering \\ Massachusetts Institute of Technology \& Woods Hole Oceanographic Institution on \\ May $6^{\text {th }} 2021$ in partial fulfillment of the requirements for the degree of Doctor of Philosophy
}

\begin{abstract}
Nearly 1.5 million people inhabit barrier islands along the U.S. Atlantic and Gulf Coasts and coastal groundwater dynamics influence the availability of freshwater, ecosystem health, pollutant transport, and flooding in these densely populated communities. However, groundwater dynamics, including the aquifer head distribution and subsurface salinity structure, in coastal aquifers are affected by multiple environmental forcings, such as waves, tides, storm surges, and precipitation that act on a variety of spatial and temporal scales, making coastal groundwater dynamics complex and difficult to predict.

Here, measurements of groundwater heads, salinities, and temperatures collected for 3 years across a 550-m-wide barrier island are used in conjunction with observations of ocean tides, surge, waves, sound level, and rainfall to characterize the dynamics of the surface aquifer. Infiltration from surge, tides, and waves during storms caused up to $2 \mathrm{~m}$ increases in the groundwater level under the dune. The head gradients owing to these storm-induced groundwater bulges suggest flows become inland directed on the ocean-side of the island during storms. An upper saline plume (20-30 PSU) was observed above fresher (10 PSU) water up to $30 \mathrm{~m}$ inland of the dune face, which was the maximum wave runup location. Differences in inland propagation between tidal- and storm-induced groundwater head fluctuations are explained using analytical theories for intermediate depth aquifers. Additionally, a separate analytical water-table evolution model driven with estimated ocean shoreline water levels (based on the 36-hr-averaged offshore tide, surge, and wave height) and measured precipitation is validated by citizen-science flood reports and predicts the maximum water-table height within $0.1 \mathrm{~m}$ of the observed levels across the barrier island.
\end{abstract}

Thesis Supervisor: Britt Raubenheimer

Title: Senior Scientist, Applied Ocean Science and Engineering

Woods Hole Oceanographic Institution 


\section{Acknowledgements}

Funding for this research was provided by the U.S. Coastal Research Program, the National Science Foundation, a National Science Foundation Graduate Research Fellowship, the Woods Hole Oceanographic ISP program, and National Security Science \& Engineering and Vannevar Bush Faculty Fellowships

An entire village of people provided the academic and personal support that made this thesis possible and I am forever grateful.

First, thank you to Britt Raubenheimer and Steve Elgar. Britt, you have guided me through every step of the scientific process over the past 5+ years, from learning how to do basic research, to field work planning, to writing reviews and proposals. I have grown so much from your mentorship and I cannot imagine having better training for the next stage of my career. Steve, thanks for letting us drag you out of the surf zone and into the world of groundwater and always being such an enthusiastic sounding board for ideas. Both of you have invested a lot in me personally and professionally and taught me so much about research, fieldwork, and coastal science. No walk on the beach will ever be the same.

Thanks to my committee members Heidi Nepf, Charles Harvey, and Holly Michael, whose perspectives and insightful discussions have helped shape this thesis to be the best possible. I have tremendously enjoyed getting to work with all of you.

Maintaining a network of groundwater wells has taken a lot of inventiveness, persistence, and in one unusual case, several packages of nylon stockings. Thanks to the entire PVLAB field team who helped with this effort, Emmett, Fred (a.k.a. the wasp killer), Bill, Paul and Suzi. Special thanks to our head engineer Levi who has taught me a lot about the logistics of coastal fieldwork, saved our wells from getting eaten by deer, and resurrected my computer from the brink of death.

The work in this thesis would not have been possible without the support of the staff at the US Army Corps of Engineers Field Research Facility. Thanks to Heidi Wadman, Jesse McNinch, Kent Hathaway, Kate Brodie and Pat Dickhudt for help maintaining the groundwater wells and accessing Field Resarch Facility data.

Thanks to the PVLAB students past and present, Ciara, Jinshi, Mara, Melissa, Julia, and Anna for being an excellent network to turn to for career guidance and science help.

Thanks to the COFDL and EFM students and postdocs, practicing presentations, troubleshooting analysis, and discussing with all of you has been so much fun.

Thanks to James Heiss, Ann Mulligan, Clarissa Murray and Ming Wu for helping me learn how to run groundwater models. 
Many thanks to the MIT/WHOI Academic Programs Office and WHOI staff and security, for all their work to keep the joint program and our research endeavors running.

Thank you to my undergrad and postgrad mentors, Jaye Cable, Johanna Rosman, and Jennifer Richmond-Bryant who helped me develop the skills needed to be successful graduate student, encouraged me to pursue graduate school, and wrote many application and fellowship recommendation letters on my behalf.

To my friends, I could not have made it to the end of this program without all of you. We have experienced so much together over these past few years. Thanks for all the pick-up sports, book clubs, group dinners, murder mysteries, hikes, concerts and game nights, you all have made this time so enjoyable.

Finally, I want to thank my family whose unwavering support and encouragement has been the foundation of all of my accomplishments. Molly, your creativity and determination are always an inspiration and I have loved getting to have you in New England with me these past few years. I can't wait to see what you will "master" next. Mom and Dad, thank you for being my most ardent supporters through every stage of my life and helping me keep perspective through the highs and lows of this academic journey. 


\section{Table of Contents}

Chapter 1: Introduction ....................................................................................................................................10

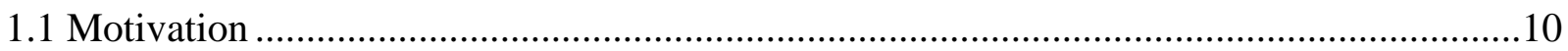

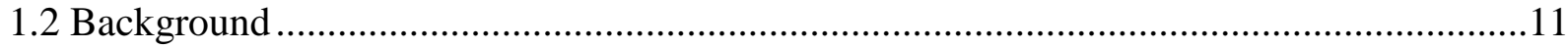

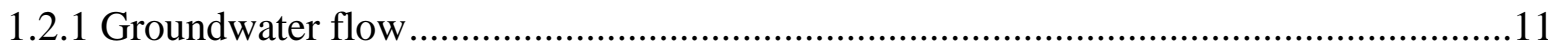

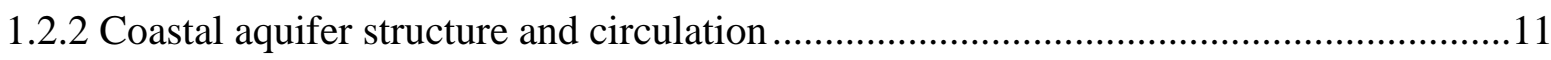

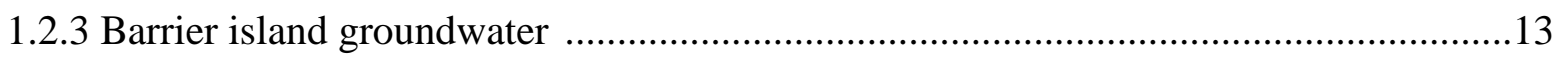

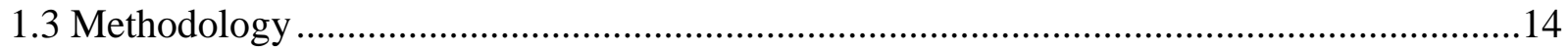

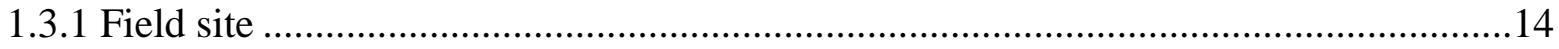

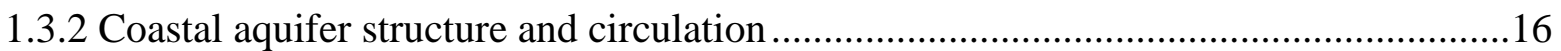

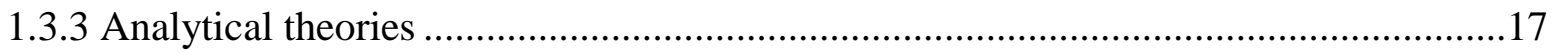

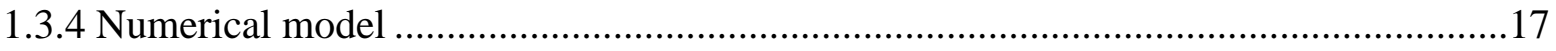

1.3.5 iFlood citizen science app .............................................................................18

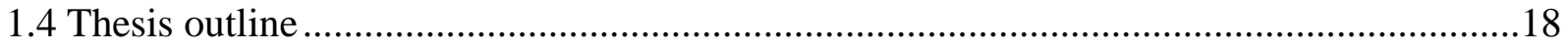

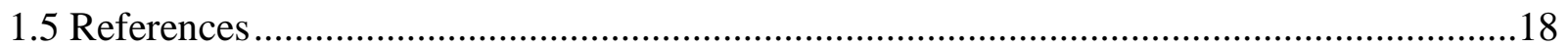

Chapter 2: Observations of fluid exchanges between ocean, sound and groundwater a across a barrier island ...........................................................................................................23

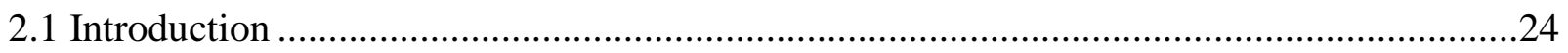

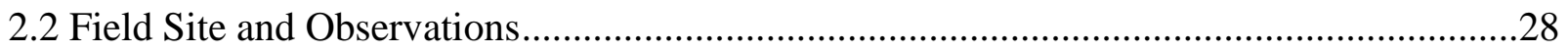

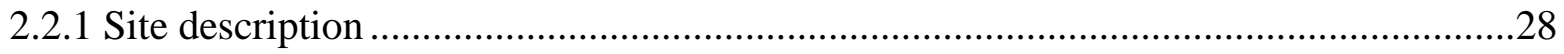

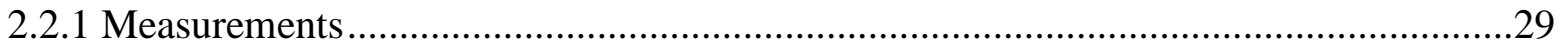

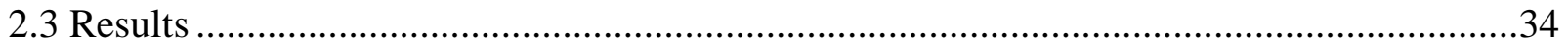

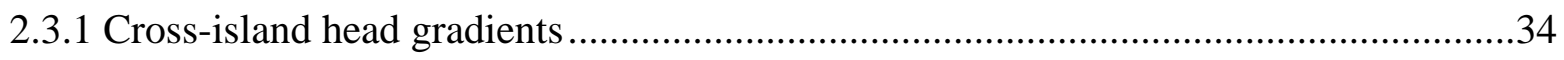

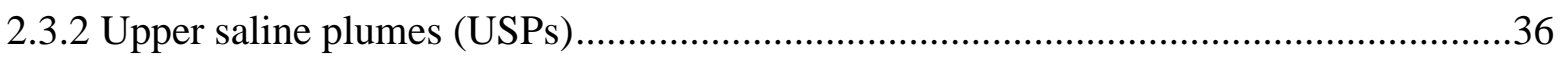

2.3.3 Influence of beach topography on USPs ....................................................................4

2.3.4 Seasonal temperature ..............................................................................................

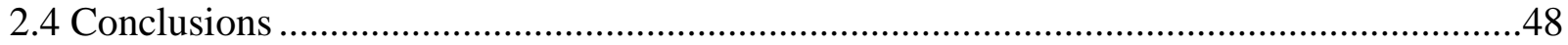

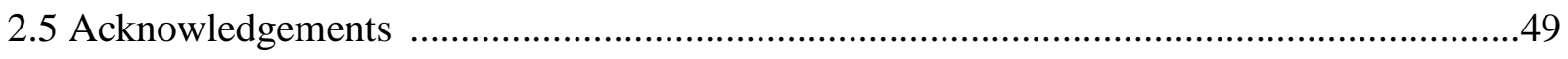

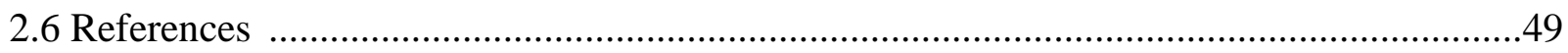




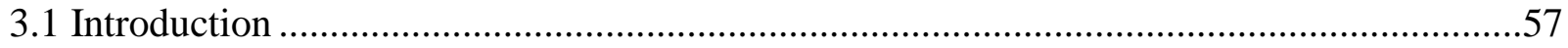

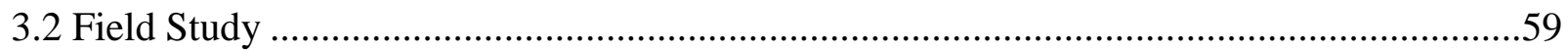

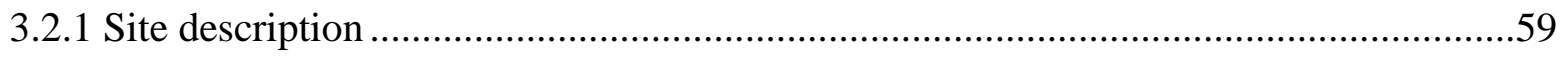

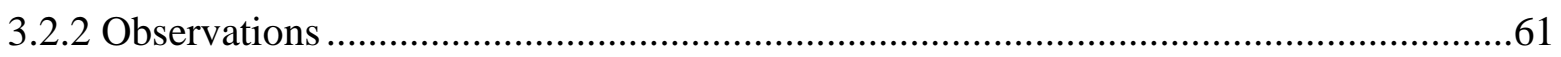

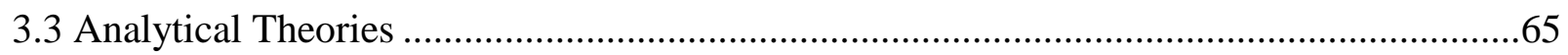

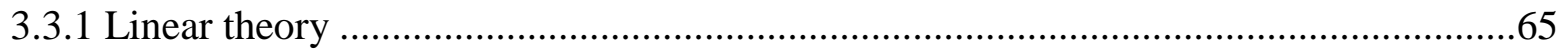

3.3.2 Higher-order intermediate depth theories .................................................................66

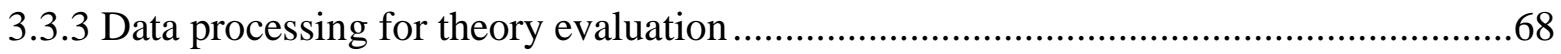

3.4 Observational Estimates of Cross-shore Propagation and Vertical Structure of

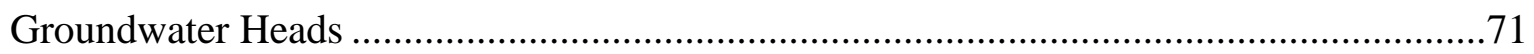

3.5 Numerical Simulations for a Homogeneous Intermediate Depth Aquifer ............................77

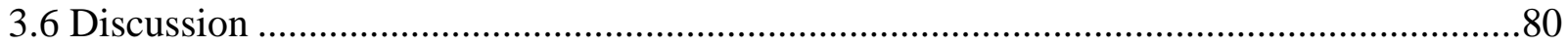

3.6.1 Estimating aquifer properties from ocean-drive head fluctuations ..............................80

3.6.2 Inland heads, saline plumes, and estimating groundwater head fluctuation .................83

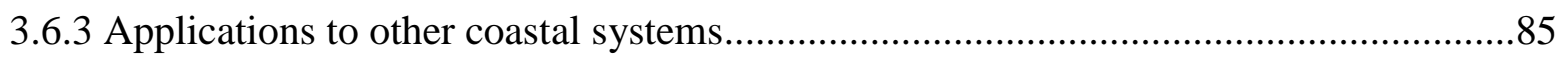

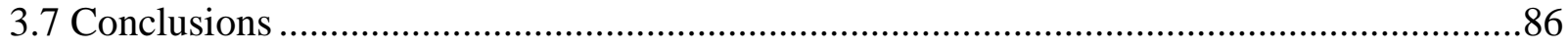

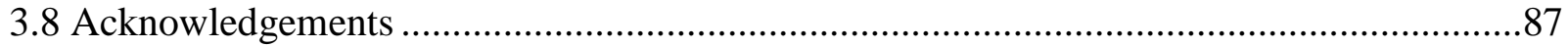

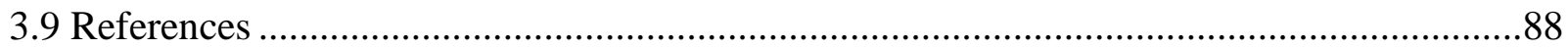

Chapter 4: Flooding owing to high groundwater driven by rain and shoreline water

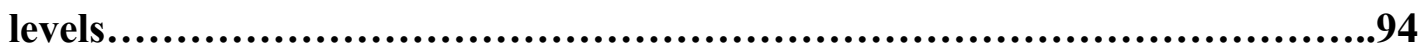

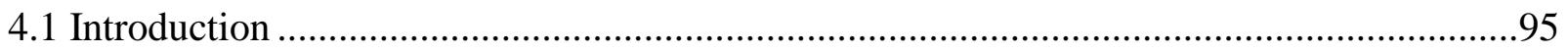

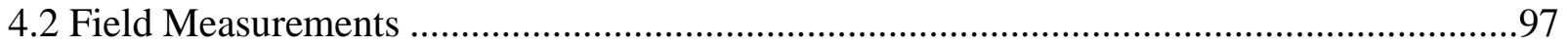

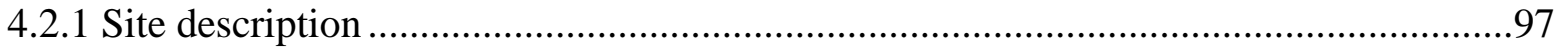

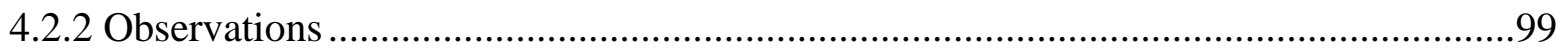

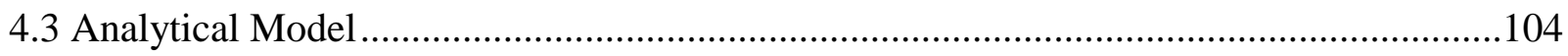

4.3.1 Groundwater pulse theory evaluation....................................................................104

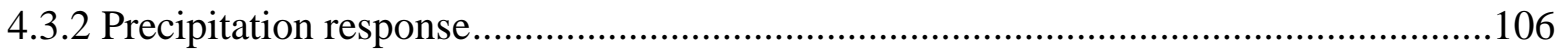

4.4 Flooding on the North Carolina Outer Banks …………..............................................107

4.4.1 iFlood citizen-science app ..........................................................................................107

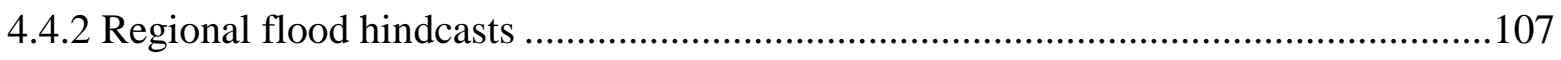


4.4.3 Regional flood vulnerability forecasts..............................................................112

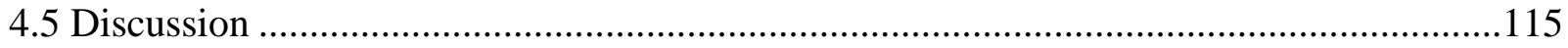

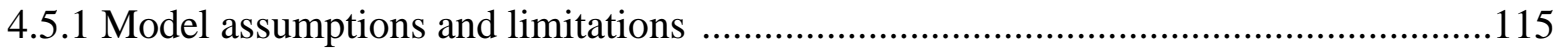

4.5.2 Future management of groundwater flooding on the Outer Banks ..........................117

4.5.3 Use of phone apps for research and increasing community awareness.....................119

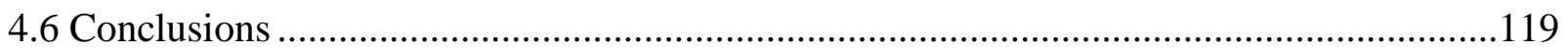

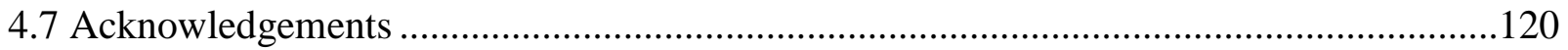

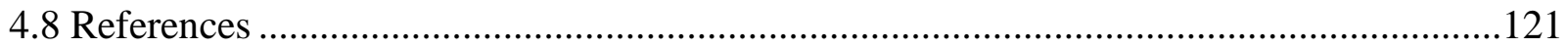

Chapter 5: Conclusions and Future Work ......................................................................................128

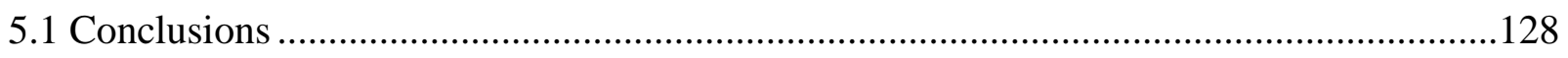

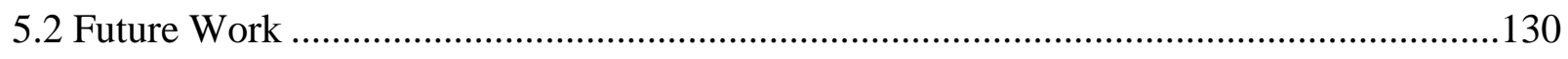

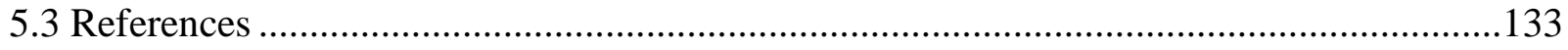

Appendix: Analytical Groundwater Pulse Model................................................................135 


\section{Chapter 1: Introduction}

\subsection{Motivation}

Nearly 1.5 million people inhabit barrier islands along the U.S. Atlantic and Gulf Coasts and the population density on barrier islands is approximately three times greater than that of coastal states (Zhang \& Leathermen, 2011). Many communities in these regions rely on the groundwater supply in the coastal aquifer for drinking water. Coastal groundwater also supports the health of the ecohydrological ecosystem and exchanges between the aquifer and adjacent surface waters are an important transport pathway for nutrients and pollutants (Charette \& Sholkovitz, 2002, 2006; Slomp \& Van Cappellen, 2004). Additionally, the low elevations (close to mean sea level, MSL) and high density of infrastructure make coastal counties susceptible to devastating environmental and economic impacts from flooding. The position of the coastal water table can influence the location and duration of flooding, and compound flooding driven by multiple hazards, such as rain and storm surge, can magnify the duration and extent of flood impacts. Consequently, quantifying feedbacks between oceanography, hydrogeology, meteorology and geomorphology (here, waves and storm surge, sound water levels, groundwater, precipitation, and beach topography) has been identified as a research priority for assessing coastal hazards and sustainable resource management (Elko et al. 2019). 


\subsection{Background}

\subsubsection{Groundwater Flow}

Groundwater flows are directed from high hydraulic head, the combined potential resulting from pressure and elevation, to low hydraulic head. The rate of fluid flow is a function of both the fluid and the porous material the water is flowing through and can be described using Darcy's law:

$$
q=K \nabla h
$$

where $q$ is the Darcy flux, or flow rate per unit surface area, $h$ is the hydraulic head and $K$ is the hydraulic conductivity, which describes the ease with which a fluid can flow through a porous medium. Additionally, in coastal settings, exchanges between the aquifer and the ocean generate mixing between salty ocean water and fresher terrestrially derived water, resulting in densitydriven flows. Hydraulic head also accounts for density-driven differences in potential. Hydraulic head can be expressed as:

$$
h_{f}=\frac{p}{\rho_{f} g}+z_{s}
$$




\subsubsection{Coastal Aquifer Structure and Circulation}

Groundwater dynamics in coastal aquifers are complex because the hydraulic head distribution and subsurface salinity structure are affected by multiple environmental forcings such as waves, tides, storm surge, and precipitation that act on a variety of spatial and temporal scales. Fluctuations in ocean water levels owing to tides and storms cause fluctuations in the groundwater level at the surface aquifer-ocean interface, which generate waves that propagate inland (Anderson \& Lauer, 2008; Cartwright et al., 2004; Cartwright \& Gibbes, 2011; Erskine, 1991; Ferris, 1951; Jacob, 1950; Nielsen, 1990; Raubenheimer et al., 1999; Rotzoll \& El-Kadi, 2008; Trglavcnik et al., 2018). The hydraulic gradients resulting from the groundwater waves influence mixing between ocean water and freshwater within the aquifer, affect the fate and transport of contaminants, and modulate the rate of groundwater discharge to the ocean (Boufadel et al., 2007; Moore, 2010; Robinson et al., 2006; Robinson et al., 2014).

In addition to increasing the head near the shoreline, infiltration and exfiltration of seawater driven by waves, tides, and storm surge create a circulation cell of high density water above the fresher terrestrial groundwater known as an upper saline plume (USP, Figure 1.1) (Abarca et al., 2013; Heiss \& Michael, 2014; Robinson et al., 2006, 2007a, 2014; Xin et al., 2010). Field observations and numerical simulations have shown that the USP will expand and contract in response to changes in oceanic water levels driven by tides (Abarca et al., 2013; Boufadel et al., 2011; Heiss \& Michael, 2014; Robinson et al., 2007b) and waves (Geng et al., 2014; Robinson et al., 2014; Xin et al., 2010). Simulations suggest hydraulic conductivities $>10 \mathrm{~m} / \mathrm{d}$ and steeper beach slopes facilitate the formation of a larger USP (Evans \& Wilson, 2016). Seasonal variation in inland head and beach topography also influence the spatial extent of the USP and multiple 
USPs may be present in beaches with sharp topographic transitions (Abarca et al. 2013, Evans \& Wilson, 2016; Heiss \& Michael, 2014). Deeper in the aquifer the saltwater wedge is an interface between terrestrially derived freshwater and intruding oceanic water. The position of the saltwater interface is controlled by the elevation of the inland freshwater head, and oscillates in response to tides and surge (Cooper 1959, Ghyben, 1888, Herzberg, 1901). Near the saltwater wedge interface, density-driven convection drives the circulation, but these flows are several orders of magnitude slower than the wave and tide driven flows within the USP (Robinson 2007a). Salt water diffuses into the fresher groundwater from both the USP and the salt wedge.

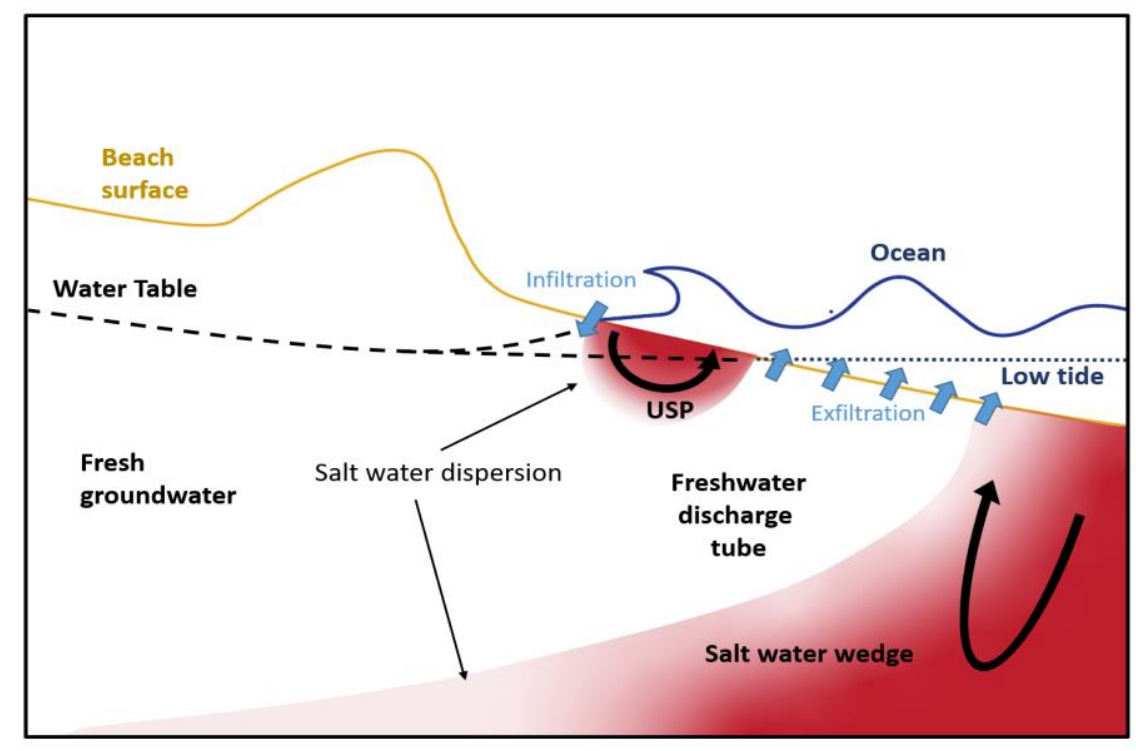

Figure 1.1: Conceptual diagram of the circulation and salinity structure in a coastal aquifer. Waves and tides (blue curve) drive aquifer-ocean exchange along the beach surface (tan curve). Ocean water that infiltrates into the aquifer due to wave and tide forcing exfiltrates near the intersection of the low tide ocean level (dashed blue line) and the beach, creating a seawater recirculation cell called an upper saline plume (USP). Offshore of the USP, fresh inland groundwater discharges to the ocean. Seawater driven inland by density gradients forms a salt water wedge in the deep aquifer. 


\subsubsection{Barrier Island Groundwater}

Barrier island groundwater is affected by both ocean and sound processes. Groundwater head fluctuations driven by different surface water bodies may interact within the aquifer (Huang et al. 2015; Colyar 2016; Li et al. 2000). In addition, in a barrier island system the rainwater catchment area is smaller than in mainland systems and groundwater can drain towards both the ocean and the sound. As a result, barrier islands have lower inland groundwater levels than mainland systems. Prior experiments have shown storm-driven increases in the groundwater water level may be sufficient to elevate the groundwater level near the beach above the inland level and reverse the direction of groundwater flow (Turner et al., 2014). Additionally, because the average water table usually is higher than MSL and lies within a few meters of the land surface in low relief regions these storm-driven increases may be sufficient to cause groundwater flooding (Befus et al. 2020; Glover 1959; Rotzoll \& Fletcher 2013;). Prior numerical and laboratory studies of coastal groundwater are usually designed for mainland systems with high inland heads and field observations of barrier island groundwater typically have spanned no more than a single springneap tidal cycle or ocean storm event (Cartwright et al., 2004; Robinson et al., 2007b; Werner et al., 2013). Long-term spatially distributed measurements within the aquifer and throughout the nearshore system (e.g. ocean and sound levels, precipitation, beach topography) are needed to characterize these ocean-and-sound-driven exchanges within the aquifer and evaluate theories describing the groundwater dynamics in a barrier island system. 


\subsection{Methodology}

\subsubsection{Field Site}

The North Carolina Outer Banks is a 320-km long chain of barrier islands extending south from the Virginia-North Carolina state line to Bogue Inlet. The islands are up to 3-km wide, and have ocean-shoreline dunes from less than 1- to 12-m high (Elko et al. 2002). The North Carolina Outer Banks is part of the North Carolina Coastal Plain aquifer system, and the shallow geology is a 50-70 m thick Quaternary sequence that fills the Albemarle Embayment (Lautier 2009; Winner \& Coble, 1996). The surficial aquifer typically is comprised of $>70 \%$ sand (Winner \& Coble, 1996). Field measurements are collected at the U.S. Army Corps of Engineers Coastal Hydraulics Laboratory Field Research Facility (FRF, http://www.frf.usace.army.mil) in Duck, NC (Figure 1.2). The property is bordered on the west by Currituck Sound and on the east by the Atlantic Ocean (Figure 1.2a). On the ocean-side of the island, the beach is backed by $\sim 7-\mathrm{m}$-high vegetated dunes. Sediment samples collected during construction of the FRF facility (Meisburger et al. 1989) and during installation of the groundwater wells suggest that the surficial aquifer is composed of medium quartz sand (mean diameter $\sim 0.25 \mathrm{~mm}$ ) and shell hash. Prior studies suggest the uppermost confining layer is roughly 15 to $30 \mathrm{~m}$ below NAVD88 (Meisburger et al. 1989; Manahan et al. 1998). 


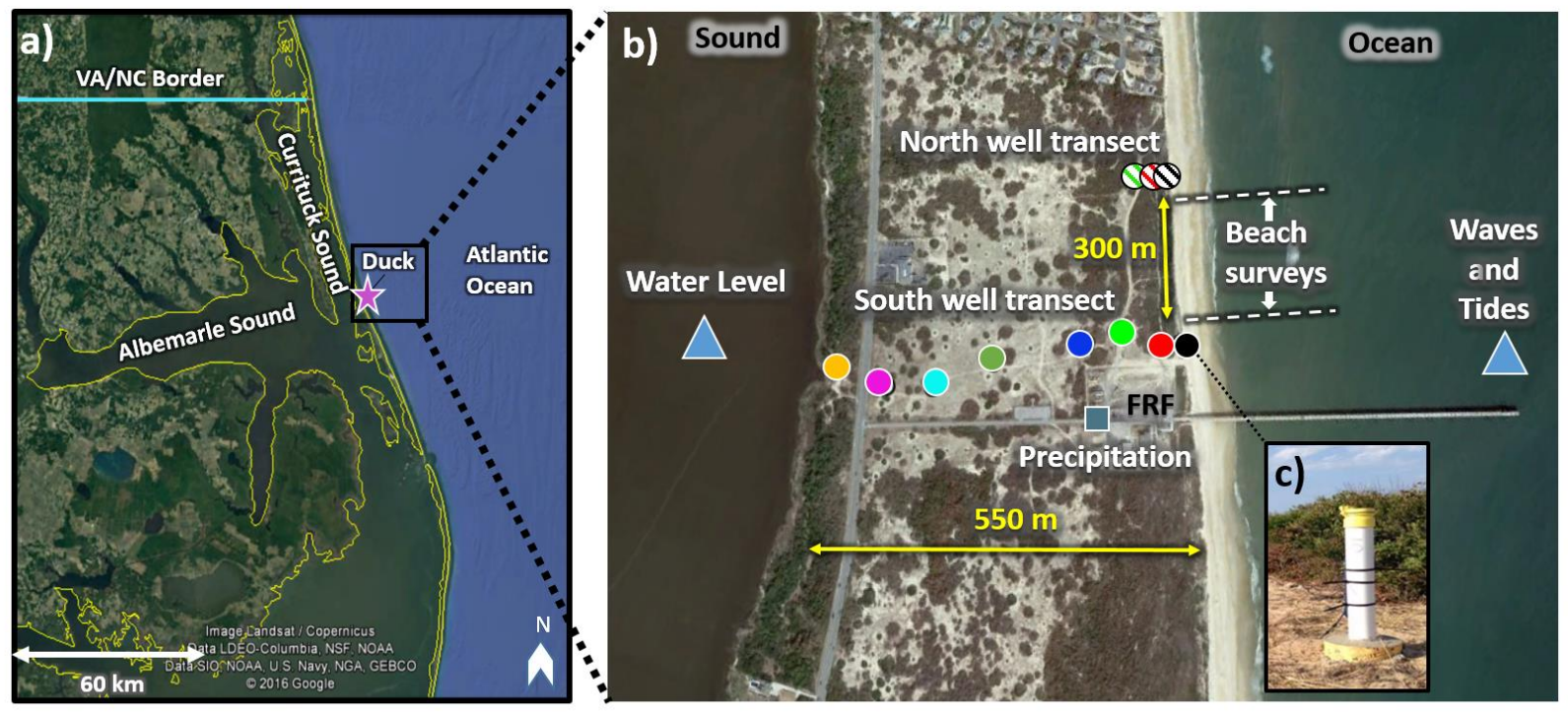

Figure 1.2: a) Google Earth image of the North Carolina Outer Banks. The border of the land is outlined in yellow. The Duck, NC U.S. Army Corps of Engineers Field Research Facility (FRF) is indicated by the purple star and is located on a barrier island between Currituck Sound and the Atlantic Ocean. b) Aerial view of the groundwater wells (filled and striped circles) and locations of FRF measurements used in the analysis: ocean and sound levels (blue triangles), precipitation (dark teal square), and beach surveys (white dashed lines) c) photograph of groundwater well.

The North Carolina Outer Banks typically experiences at least one large storm (offshore wave heights $>5 \mathrm{~m}$ ) during the fall/winter annually (Figure 1.3). These storms generate significant increases in the ocean water level at the shoreline and waves have been observed to run up the dune face during several of these events. Based on prior studies, these storms will significantly affect the cross-island head distribution and groundwater flow pattern, and have long-term impacts on the salinity structure within the aquifer. Groundwater-induced flooding has been reported several days following storms at locations a few hundred meters inland of the beach near Duck $\mathrm{NC}$, possibly owing to enhanced inland migration of the storm-induced groundwater bulge enabled by the relatively low inland groundwater heads (personal communication, Duck town managers). 


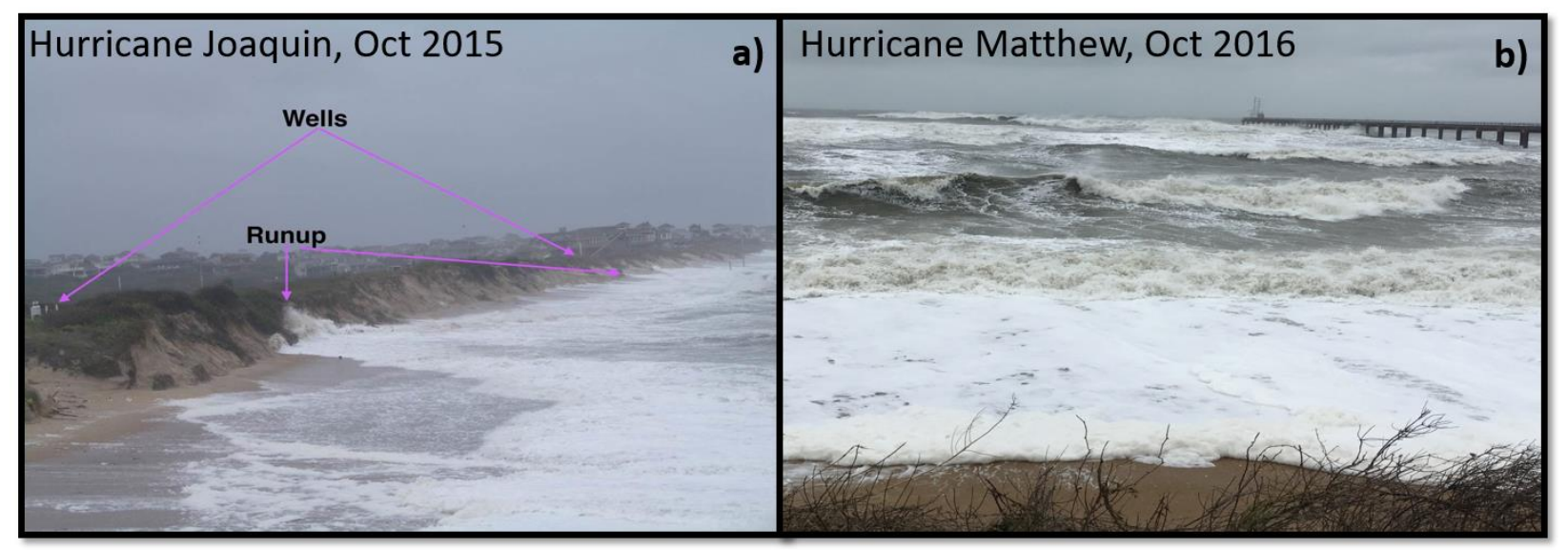

Figure 1.3: Photographs of the surf and swash zone near Duck, NC during a) Hurricane Joaquin, Oct 2015 and b) Hurricane Matthew, Oct 2016

\subsubsection{Observations}

In September 2014, 19 groundwater wells were installed at 8 locations along a 550-m-long transect across the barrier island extending from the ocean dune to the sound (Figure 1.2b, referred to subsequently as the southern transect). In April of 2015, a second transect of 11 wells was installed at 3 locations under and behind the ocean dune $300 \mathrm{~m}$ north of the southern transect (sites n0, n20, n40, referred to subsequently as the northern transect). Inside each well a conductivitytemperature-depth (CTD) sensor samples at 10-minute intervals. The FRF collects ocean (wave and tide), sound (water level), bathymetric, and topographic measurements, which are used in conjunction with the well observations to connect changes in groundwater behavior to hydrodynamic and morphologic conditions. These observational data are the foundation for this thesis.

\subsubsection{Analytical Theories}

Analytical solutions describe the propagation of tidal (the Jacob-Ferris model, Ferris, 1951; Jacob, 1950; Nielsen 1990; Nielsen et al. 1997) and storm-driven (Li et al., 2004) groundwater 
waves through homogeneous, isotropic, shallow coastal surface aquifers with vertical ocean boundaries. These theories are applied to the observational data to explain differences in inland propagation between tidal- and storm-induced groundwater head fluctuations and predict the crossisland evolution of the groundwater table in response to storms.

\subsubsection{Numerical Model}

MODFLOW-NWT, a constant-density groundwater flow and transport numerical model (Niswonger et al. 2011), is used to help support the interpretation of the observational groundwater data. The analytical theories applied during the analysis of the observational data contain simplifying assumptions that do not reflect the natural environment (e.g. assuming a vertical beach face or constant inland head). The 2-dimensional model domain designed for this study represents a vertical cross-section that extends from $200 \mathrm{~m}$ inland of the ocean dune (between the blue and dark green circles Figure $1.2 \mathrm{~b}$ ) to $250 \mathrm{~m}$ offshore of the dune. The model provides a framework for testing the validity of assumptions and improving the characterization of the aquifer subsurface.

\subsection{5 iFlood Citizen Science App}

A citizen-science phone application (app), iFlood, was released in September 2019 to collect flood information, including location, depth, recent rainfall, and photographs on the North Carolina Outer Banks. Since field observations are only collected in Duck, data reported to the iFlood app is used to expand the regional scope of the analysis.

\subsection{Thesis Outline}

This thesis is divided into three chapters investigating the barrier island aquifer dynamics

resulting from feedbacks between ocean and sound driven-forcings, hydrologic and 
meteorological processes, and morphological changes, including the response to several major hurricanes. Chapter 2 presents observations of fluid exchanges between the coastal aquifer and the adjacent surface water bodies: the Atlantic Ocean ( $\sim 35$ PSU, wave, tide, and surge driven changes in shoreline water level) and Currituck Sound ( 1-2 PSU, wind-driven changes in the shoreline water level). The chapter describes how the cross-island heads and the subsurface salinity and temperature structure are affected by storm-driven changes in the sound and ocean water level, beach topography, and seasonal variations in air and ocean temperatures. In Chapter 3, observations of ocean water levels and groundwater heads are used to evaluate linear and higherorder intermediate-depth theories for the inland propagation of the groundwater head fluctuations resulting from storms and tides. In Chapter 4 , an analytical model to predict the timing and location of groundwater-driven flooding resulting from ocean surge and precipitation is calibrated and validated using observations and citizen-science flood reports. The model is applied to predict regions of groundwater flood vulnerability across a 50-km section of the North Carolina Outer Banks during a storm with shoreline water level increase consistent with a hurricane or large nor'easter. The results of this thesis project will inform coastal management and improve hazard predictions for sandy barrier island systems.

\subsection{References}

Abarca, E., Karam, H., Hemond, H., \& Harvey, C. (2013). Transient groundwater dynamics in a coastal aquifer: The effects of tides, the lunar cycle, and the beach profile. Water Resources, 49(5), 2473-2488.

Anderson, W. P. J., \& Lauer, R. M. (2008). The role of overwash in the evolution of mixing zone morphology within barrier islands. Hydrogeology Journal, 16(8), 1483-1495. 
Befus, K. M., Barnard, P. L., Hoover, D. J., Finzi Hart, J. A., \& Voss, C. I. (2020). Increasing threat of coastal groundwater hazards from sea-level rise in California. Nature Climate Change, 10, 946-952.

Boufadel, M. C., Li, H., Suidan, M. T., \& Venosa, A. D. (2007). Tracer studies in a laboratory beach subjected to waves. Journal of Environmental Engineering, 133(7), 722-732. https://doi.org/10.1061/(ASCE)0733-9372(2007)133:7(722)

Boufadel, M. C., Xia, Y., \& Li, H. (2011). Modeling solute transport and transient seepage in a laboratory beach under tidal influence. Environmental Modelling \& Software, 26(7), 899912. https://doi.org/10.1016/j.envsoft.2011.02.005

Cartwright, N., \& Gibbes, B. (2011). Oceanic pulse forcing of a beach groundwater system. In Coasts and Ports 2011 : Diverse and Developing: Proceedings of the 20th Australasian Coastal and Ocean Engineering Conference and the 13th Australasian Port and Harbour Conference.

Cartwright, N., Nielsen, P., \& Li, L. (2004a). Experimental observations of watertable waves in an unconfined aquifer with a sloping boundary. Advances in Water Resources, 27(10), 9911004. https://doi.org/10.1016/J.ADVWATRES.2004.08.006

Cartwright, N., Li, L., \& Nielsen, P. (2004b). Response of the salt-freshwater interface in a coastal aquifer to a wave-induced groundwater pulse: field observations and modelling. Advances in Water Resources, 27(3), 297-303. https://doi.org/10.1016/j.advwatres.2003.12.005

Charette, M. A., \& Sholkovitz, E. R. (2002). Oxidative precipitation of groundwater-derived ferrous iron in the subterranean estuary of a coastal bay. Geophysical Research Letters, 29(10), 85-1-85-4. https://doi.org/10.1029/2001GL014512

Charette, M. A., \& Sholkovitz, E. R. (2006). Trace element cycling in a subterranean estuary: Part 2. Geochemistry of the pore water. Geochimica et Cosmochimica Acta, 70(4), 811826. https://doi.org/10.1016/j.gca.2005.10.019

Colyar, M. A (2016). The influence of tides, waves, and overtopping on the near-shore water table. UC Irvine. ProQuest ID: Colyar_uci_0030M_14174. Merritt ID: ark:/13030/m5km40sp.

Cooper, H. H. (1959). A hypothesis concerning the dynamic balance of fresh water and salt water in a coastal aquifer. Journal of Geophysical Research, 64(4), 461-467. https://doi.org/10.1029/JZ064i004p00461 
Elko, N. A., Sallenger, A. H., Guy, K., Stockdon, H. F., \& Morgan, K. L. M. (2002). Barrier Island Elevations Relevant to Potential Storm Impacts: 1. Techniques. US Geological Survey Open File Report, 02-287.

Elko, N., Dietrich, C., Cialone, M. A., Stockdon, H., Bilskie, M. W., Boyd, B., et al. (2019). Advancing the understanding of storm processes and impacts. Shore \& Beach.

Erskine, A. D. (1991). The Effect of Tidal Fluctuation on a Coastal Aquifer in the UK. Ground Water, 29(4), 556-562. https://doi.org/10.1111/j.1745-6584.1991.tb00547.x

Evans, T. B., \& Wilson, A. M. (2016). Groundwater transport and the freshwater-saltwater interface below sandy beaches. Journal of Hydrology, 538, 563-573. https://doi.org/10.1016/j.jhydrol.2016.04.014

Ferris, J. G. (1951). Cyclic fluctuations of water level as a basis for determining aquifer transmissibil. IAHS Publ., 33, 148-155.

Geng, X., Boufadel, M. C., Xia, Y., Li, H., Zhao, L., Jackson, N. L., \& Miller, R. S. (2014). Numerical study of wave effects on groundwater flow and solute transport in a laboratory beach. Journal of Contaminant Hydrology, 165, 37-52. https://doi.org/10.1016/j.jconhyd.2014.07.001

Ghyben, B. W. (1888). Nota in verband met de voorgenomen putboring nabij, Amsterdam. The Hague, 21.

Glover, R. E. (1959). The pattern of fresh-water flow in a coastal aquifer. Journal of Geophysical Research, 64(4), 457-459. https://doi.org/10.1029/jz064i004p00457

Heiss, J. W., \& Michael, H. A. (2014). Saltwater-freshwater mixing dynamics in a sandy beach aquifer over tidal, spring-neap, and seasonal cycles. Water Resources Research, 50(8), 6747-6766. https://doi.org/10.1002/2014WR015574

Herzberg, A. (1901). Die wasserversorgung einiger Nordseebader. J. Gasbeleucht. Wasserversorg., 44, 842-844.

Huang, F. K., Chuang, M. H., Wang, G. S., \& Yeh, H. Der. (2015). Tide-induced groundwater level fluctuation in a U-shaped coastal aquifer. Journal of Hydrology, 530, 291-305. https://doi.org/10.1016/j.jhydrol.2015.09.032

Jacob, C. E. (1950). Flow of groundwater. Engineering Hydraulics, 321-386.

Lautier, J. C. (2009). Hydrogeologic Framework and Ground Water Conditions in the North Carolina East Central Coastal Plain. 
Li, L., Barry, D. A., Cunningham, C., Stagnitti, F., \& Parlange, J. Y. (2000). A two-dimensional analytical solution of groundwater responses to tidal loading in an estuary and ocean. Advances in Water Resources, 23(8), 825-833. https://doi.org/10.1016/S0309$\underline{1708(00) 00016-6}$

Li., L., Cartwright, N., Nielsen, P., \& Lockington, D. (2004). Response of coastal groundwater table to offshore storms. China Ocean Engineering, 18(3), 423-431.

Manahan, S., Martin, W. K., \& Guo, W. (1998). Dare County-wide Hydrogeological Study and Groundwater Resource Evaluation. Dare County Water Production Department, Kill Devil Hills, NC.

Meisburger, E. P., Williams, S. J., \& Judge, C. (1989). Physiographic and Geological Setting of the Coastal Engineering Research Center's Field Research Facility. Vicksburg, MS.

Moore, W. S. (2010). The Effect of Submarine Groundwater Discharge on the Ocean. Annual Review of Marine Science, 2(1), 59-88. https://doi.org/10.1146/annurev-marine-120308081019

Nielsen, P. (1990). Tidal dynamics of the water table in beaches. Water Resources Research, 26(9), 2127-2134. https://doi.org/10.1029/WR026i009p02127

Nielsen, P., Aseervatham, R., Fenton, J. D., \& Perrochet, P. (1997). Groundwater waves in aquifers of intermediate depths. Advances in Water Resources, 20(1), 37-43. https://doi.org/10.1016/S0309-1708(96)00015-2

Niswonger, R. G., Panday, S., \& Motomu, I. (2011). MODFLOW-NWT, A Newton formulation for MODFLOW-2005: U.S. Geological Survey Techniques and Methods 6-A37.

Raubenheimer, B., Guza, R. T., \& Elgar, S. (1999). Tidal water table fluctuations in a sandy ocean beach. Water Resources Research, 35(8), 2313-2320. https://doi.org/10.1029/1999WR900105

Robinson, C., Li, L., \& Prommer, H. (2007). Tide-induced recirculation across the aquifer-ocean interface. Water Resources Research, 43(7). https://doi.org/10.1029/2006WR005679

Robinson, C., Gibbes, B., \& Carey, H. (2007). Salt-freshwater dynamics in a subterranean estuary over a spring-neap tidal cycle. Journal of Geophysical.

Robinson, C., Xin, P., Li, L., \& Barry, D. A. (2014). Groundwater flow and salt transport in a subterranean estuary driven by intensified wave conditions. Water Resources Research, 50(1), 165-181. https://doi.org/10.1002/2013WR013813 
Rotzoll, K., \& El-Kadi, A. I. (2008). Estimating hydraulic properties of coastal aquifers using wave setup. Journal of Hydrology, 353(1-2), 201-213.

https://doi.org/10.1016/J.JHYDROL.2008.02.005

Slomp, C. P., \& Van Cappellen, P. (2004). Nutrient inputs to the coastal ocean through submarine groundwater discharge: controls and potential impact. Journal of Hydrology, 295(1), 64-86. https://doi.org/10.1016/j.jhydrol.2004.02.018

Turner, I. L., Rau, G. C., Austin, M. J., \& Andersen, M. S. (2014). Groundwater fluxes and flow paths within coastal barriers: Observations from a large-scale laboratory experiment (BARDEX II). Coastal Engineering, 113, 104-116. https://doi.org/10.1016/j.coastaleng.2015.08.004

Werner, A. D., Bakker, M., Post, V. E. A., Vandenbohede, A., Lu, C., Ataie-Ashtiani, B., et al. (2013). Seawater intrusion processes, investigation and management: Recent advances and future challenges. Advances in Water Resources, 51, 3-26. https://doi.org/10.1016/j.advwatres.2012.03.004

Winner, M. D. J., \& Coble, R. (1996). Hydrogeologic framework of the North Carolina Coastal Plain.

Zhang, K., \& Leatherman, S. (2011). Barrier Island Population along the U.S. Atlantic and Gulf Coasts. Journal of Coastal Research, 272, 356-363. https://doi.org/10.2112/JCOASTRESD-10-00126.1 


\title{
Chapter 2:
}

\section{Observations of fluid exchanges between ocean, sound, and groundwater across a barrier island}

\begin{abstract}
Groundwater heads, salinities, and temperatures influence the fate and transport of nutrients and pollutants in coastal aquifers. Here, the effects of ocean and sound water level changes, morphological evolution, and seasonal temperature changes on groundwater heads, salinities, and temperatures measured every 10 min from Oct 2014-2016 at 11 locations spanning the 550-m-wide barrier island near Duck, NC, USA are discussed. Offshore (26-m water depth) wave heights exceeded $4 \mathrm{~m}$ approximately 8 times owing to tropical storms (including Hurricanes Joaquin (2015), Hermine and Matthew (2016) and nor'easters. Shoreline water levels were elevated at least $0.65 \mathrm{~m}$ above normal tidal levels by storm surge (measured in 6-m depth) and wave-driven setup (estimated as 0.2 times the offshore wave height) during 15 ocean windstorms. Infiltration from surge, tides, and waves caused up to $2 \mathrm{~m}$ increases in the groundwater level under the dune. The head gradients owing to these surge- and wave-induced groundwater bulges suggest flows become inland directed on the ocean side of the island during storms. An upper saline plume (20-30 PSU) was observed above fresher (10 PSU) water up to $30 \mathrm{~m}$ inland of the dune face, which was the maximum wave runup location (overtopping did not occur) during these ocean storm events. On the sound side of the island aquifer, salinity was approximately uniform in the vertical, and groundwater head fluctuations generated by wind-driven changes in the sound water level were $<0.5 \mathrm{~m}$. The measurements include observations of alongshore variations in the USP,
\end{abstract}


impacts of beach topography on groundwater structure, and seasonal variations in groundwater temperature.

\subsection{Introduction}

Barrier islands line 10\% of global coastlines (Stutz \& Pilkey, 2011), with many communities relying on the coastal aquifer for drinking water. Coastal groundwater also supports the health of the ecohydrological system and exchanges between the aquifer and adjacent surface waters are an important transport pathway for nutrients and pollutants (Charette \& Sholkovitz, 2002, 2006; Slomp \& Van Cappellen, 2004). The coastal aquifer is connected hydraulically to the ocean, and thus sea-level rise and the intensification of ocean windstorms pose a threat to groundwater resources (Befus et al. 2020; Patricola \& Wehner 2018). Understanding the dynamics and physical properties (such as groundwater head, salinity, and temperature) that influence how water and solutes move and transform throughout the barrier island aquifer is essential for managing coastal groundwater resources. However, there are few long-term observations of coastal groundwater. Here, observations of groundwater heads, salinity, and temperature collected continuously for three years are used to examine the effects of ocean storms, wind-driven fluctuations in sound water levels, morphological changes, and seasonal temperature variations across a North Carolina barrier island aquifer.

Oceanic water fluctuations driven by waves, tides, and setup increase the elevation of the water table in the coastal aquifer (Anderson \& Lauer, 2008; Cartwright et al., 2004; Raubenheimer et al., 1999; Rotzoll \& El-Kadi, 2008). In addition to causing fluctuations in groundwater heads at tidal and storm periods (Anderson \& Lauer, 2008; Li. et al., 2004), the infiltration and exfiltration of seawater create a circulation cell of high density water (the upper saline plume, USP) above the 
fresher terrestrial groundwater (Abarca et al., 2013; Heiss \& Michael, 2014; Robinson et al., 2006, 2007a, 2014; Xin et al., 2010a) (Figure 2.1). The USP influences the geochemical composition of groundwater by enhancing exchange between the aquifer and the ocean water, and by creating subsurface mixing zones between salt and freshwater (Appelo, 1994; Moore, 1999) that affect the transport of anthropogenic pollutants (Charette \& Sholkovitz, 2002, 2006; Slomp \& Van Cappellen, 2004), the habitat viability for benthic organisms (Miller \& Ullman, 2004; Zipperle \& Reise, 2005), and the distribution of microbes such as fecal indicator bacteria in the beach sediments (Gast et al., 2015).

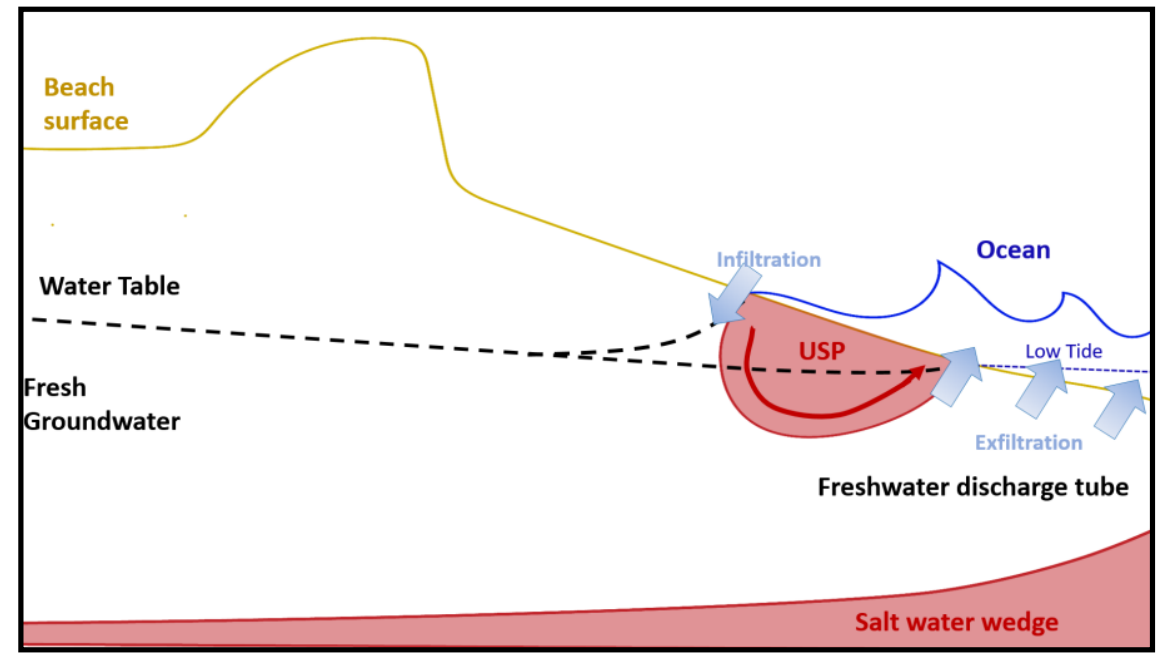

Figure 2.1: Conceptual diagram of the circulation and salinity structure in a coastal aquifer. Waves and tides (blue curve) drive aquifer-ocean exchange along the beach surface (tan curve). Ocean water that infiltrates into the aquifer due to wave and tide forcing exfiltrates at the low tide mark (dashed blue line), creating a seawater recirculation cell called an upper saline plume (USP). Beneath the USP, fresh inland groundwater discharges to the ocean. Seawater driven inland by density gradients forms a salt water wedge in the deep aquifer

Owing to the importance of the USP to coastal systems, the effects of oceanic forcing have been studied extensively in the laboratory (Boufadel 2000; Robinson \& Li, 2004; Colbert et al., 2008) and with numerical models (Abarca et al., 2013; Boufadel et al., 2011; Geng et al., 2014; 
Heiss \& Michael, 2014; Robinson et al., 2007a; Robinson et al., 2014; Xin et al., 2014). Field observations and numerical simulations have shown that the USP will expand and contract in response to changes in oceanic water levels driven by tides (Abarca et al., 2013; Boufadel et al., 2011; Heiss \& Michael, 2014; Robinson et al., 2007b) and waves (Geng et al., 2014; Robinson et al., 2014; Xin et al., 2010). Although most simulations and observations suggest that the USP is confined to the intertidal-swash zone, one numerical study suggests that the USP may form a deeper tail that extends farther inland (Boufadel et al., 2011). Numerical simulations indicate that the recovery time of the subsurface salinity distribution to the pre-storm state increases with storm duration and decreases with higher inland groundwater heads (Robinson et al., 2014), and that ocean-storm-related increased salinity may persist for more than 150 days (Robinson et al., 2014; Xin et al., 2014). Most field studies of groundwater and the USP in open ocean beaches have focused on the "intertidal-swash" region between the most onshore, submerged point at high tide and the most offshore "dry" point at low tide, and typically have spanned no more than a single spring-neap tidal cycle or ocean storm event (Cartwright et al., 2004; Robinson et al., 2007b; Werner et al., 2013), so the simulated inland structure and recovery times have not been validated.

Beach topography is important in controlling the subsurface salinity distribution. Beaches with steep foreshore slopes experience larger onshore-directed pressure gradients, but have a smaller surface area of seawater infiltration than more gently sloping beaches for a given rise in water level. As a result, USPs that form on steep beaches will extend deeper into the aquifer than USPs on flatter beaches, but will not expand as far inland (Robinson et al., 2014). Furthermore, beaches with berms or multiple slope breaks can form multiple small USPs (Evans \& Wilson, 2016; Heiss \& Michael, 2014). The position of the dune also can constrain the area of saltwater 
infiltration by preventing runup from extending inland of the base of the dune (Suanez et al., 2016). Wave action and elevated water levels during ocean storms can erode the dune and reshape the beach profile (Birkemeier et al., 1999; Lee et al., 1998; Suanez et al., 2016). Simulations of the USP have assumed a fixed beach profile, neglecting storm driven changes in beach topography that may affect the evolution of the USP (Geng et al., 2014; Robinson et al., 2014; Xin et al., 2010).

In addition to salt, heat is exchanged between the aquifer and adjacent surface water bodies, and thus temperature may be used as a tracer to measure groundwater-surface water fluxes (Befus et al., 2013; Constantz, 2008; Henderson et al., 2009; Irvine et al., 2017; Kalbus et al. 2006; Kurylyk et al., 2019; LeRoux et al., 2021; Rau et al., 2014). Heat is transported through the aquifer by both conduction and advection (Taniguchi, 1993). Consequently, the temperature distribution within the aquifer is affected by the subsurface flow patterns and density distributions. Shallow groundwater temperatures also fluctuate on seasonal (up to $10 \mathrm{~m}$ depth) and diurnal scales (1 m depth) in response to variations in atmospheric temperature fluctuations (Kurylyk et al., 2013; Taylor \& Stefan, 2009). The influence of waves and tides on temperatures in coastal aquifer system is not understood well.

Here, groundwater heads, salinities, and temperatures measured from Oct $2014-2016$ across a barrier island (Section 2.2) are used to describe the effects of ocean and sound water level fluctuations on the coastal surface aquifer. Increased ocean water levels during storms cause up to $2 \mathrm{~m}$ increases in head levels under the ocean-side dunes (Section 2.3.1), which may result in inlanddirected groundwater flow enabling the (observed) penetration of the upper saline plume inland of the dune during and following storms (Section 2.3.2). The influence of beach topography on the 
USP (Section 2.3.3) and seasonal and cross-island variations in temperature (Section 3.4) also are discussed.

\subsection{Field Site and Observations}

\subsubsection{Site Description}

The North Carolina Outer Banks is a 320-km long chain of barrier islands extending south from the Virginia-North Carolina state line to Bogue Inlet. The islands are up to 3-km wide, and have ocean-shoreline dunes from less than 1- to 12-m high (Elko et al., 2002). The North Carolina Outer Banks is part of the North Carolina Coastal Plain aquifer system, and the shallow geology is a 50-70 m thick Quaternary sequence that fills the Albemarle Embayment (Lautier, 2009; Winner \& Coble, 1996). The surficial aquifer typically is comprised of $>70 \%$ sand (Winner \& Coble, 1996). A network of paleo-channels that were backfilled with younger Pleistocene sediments also weaves through the Quartenary sequence (Lazarus \& Murray, 2011; Riggs et al. 1995). The paleo-channels contain muddy estuarine sediment, sand, and fluvial gravel (Lazarus \& Murray, 2011). Branches of the paleo-Roanoke/Albemarle fluvial system have been recorded at the shoreface in Duck, Kitty Hawk, Kill Devil Hills, and Nags Head (Boss et al. 2002; Lazarus \& Murray, 2011; Riggs et al., 1995). The surficial aquifer is underlain by a series of discontinuous clay and silt beds that comprise the Yorktown confining unit, which is estimated to occur 15-20 m below NAVD88 (approximately mean sea level) (Mallinson et al., 2010; Winner \& Coble, 1996).

Field measurements were collected at the U.S. Army Corps of Engineers Coastal Hydraulics Laboratory Field Research Facility (FRF, http://www.frf.usace.army.mil) in Duck, NC (Figure 2.2). The property is bordered on the west by Currituck Sound and on the east by the Atlantic Ocean. On the ocean side of the island, the beach is backed by $\sim 7-\mathrm{m}$-high vegetated dunes. 
Sediment samples collected during construction of the FRF facility (Meisburger et al., 1989) and during installation of the groundwater wells suggest that the surficial aquifer is composed of medium quartz sand (mean diameter $\sim 0.25 \mathrm{~mm}$ ) and shell hash. Prior studies suggest the uppermost confining layer is roughly 15 to 30 m below NAVD88 (Manahan et al., 1998; Meisburger et al., 1989). However, a confining unit was not encountered during drilling, with boreholes extending from 15 (under the dune) to $26 \mathrm{~m}$ (near the sound) below NAVD88. Slug tests (Bouwer \& Rice, 1976; Brown et al., 1995; Butler et al., 1996; Hvorslev, 1951) performed at 16 wells spanning the island suggest that the hydraulic conductivity is approximately $K=13.0 \pm 4.4$ $\mathrm{m} / \mathrm{d}$, consistent with an estimate of $14.9 \mathrm{~m} / \mathrm{d}$ obtained during drilling of a test water supply well about 2 miles south of the study site (Manahan et al., 1998). Based on these observations, the aquifer is assumed to be approximately uniform across the island.

\subsubsection{Measurements}

In Sep 2014, 19 groundwater wells were installed at 8 locations along a 550-m-long transect across the barrier island extending from the ocean dune to the sound (Figure 2.2, referred to subsequently as the southern transect). In April of 2015, a second transect of 11 wells was installed at 3 locations under and behind the ocean dune $300 \mathrm{~m}$ north of the southern transect (sites n0, n20, n40, referred to subsequently as the northern transect). The cross-shore positions $(x$, positive toward the sound) of the well locations are defined relative to the well closest to the dune face. Each well was composed of 0.05 m-diameter PVC pipe with No.10 perforated screen at the bottom surrounded by gravel pack topped with a bentonite seal. At the six mid-island locations (Figure 2.2c, $95 \leq x \leq 450 \mathrm{~m}$ ), where salinities are $<1$ PSU, wells extended 9 to $10 \mathrm{~m}$ below NAVD88 with 8- to 9-m-long screens. Near the ocean (Figure 2.2b, filled and striped red and black 
circles) and near the sound (Figure 2.2b, orange circle), well clusters (Figure 2.2c) were installed to measure the vertical variation in the groundwater structure without sample compositing (Elci et al., 2001; Levanon et al., 2013). Wells in the clusters had 0.6-m-long well screens so that water could be extracted from a targeted depth in the aquifer. Each well cluster was arranged in a shoreparallel line with $3 \mathrm{~m}$ spacing between each well. Shallow and deep wells were staggered to minimize interference between wells. The ocean-side clusters consisted of 5 wells installed at depths ranging from $-1 \mathrm{~m}$ to $-15 \mathrm{~m}$ (NAVD88, approximately mean sea level) and the sound cluster consisted of four wells drilled to depths from -1 to $-17 \mathrm{~m}$ (Figure $2.2 \mathrm{c}$ ).
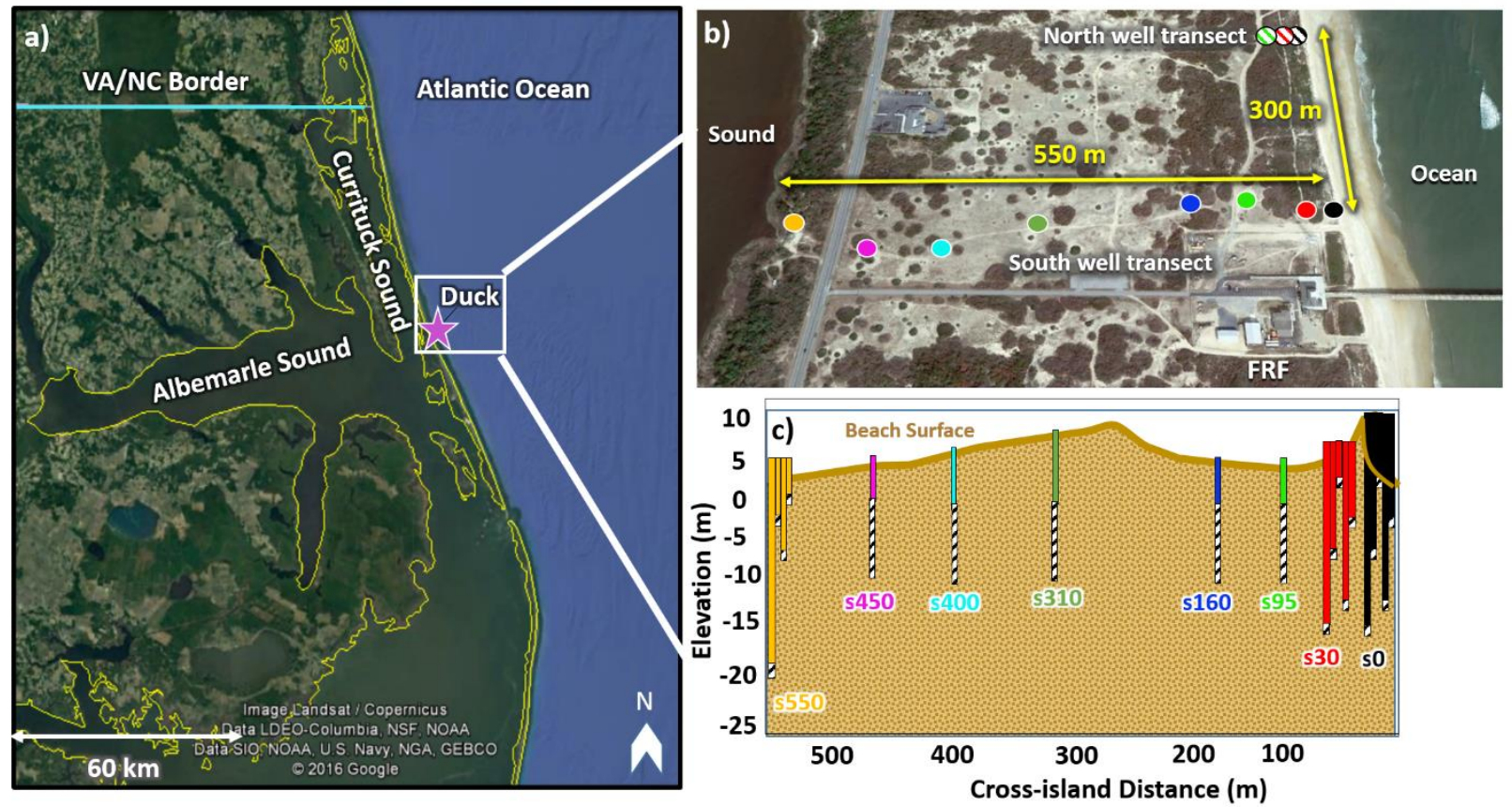

Figure 2.2: a) Google Earth image of northeastern North Carolina, including the Outer Banks. The land is outlined in yellow. The U.S. Army Corps of Engineers Field Research Facility (FRF, purple star in the white box), Duck, NC is located on a barrier island between Currituck Sound and the Atlantic Ocean. b) Close-up view of the barrier island showing the locations of groundwater wells (colored circles) extending from the ocean dune to the sound. c) Elevation of the beach surface (tan curve) relative to NAVD88 and groundwater wells (long, colored rectangles) versus distance from the well closest to the ocean. The cross-hatched region on each well is the screened section. Vertical clusters $(\mathrm{n} 0, \mathrm{n} 20)$ at the North well transect (not shown) are at comparable elevations. 
Conductivity-temperature-depth (CTD) sensors at about mid-screen-elevation in each well were sampled at 10-min intervals. Water density was calculated from the measured salinity, temperature, and pressure (Fofonoff \& Millard, 1983). The sensors were vented to the atmosphere so that pressure measurements were not influenced by fluctuations in barometric pressure. Sensor elevations were estimated using differential GPS measurements of the well cap, and simultaneous water-level measurements (from a standard meter) and pressure and water density measurements from the in situ sensors. Annual re-estimates show less than $0.02 \mathrm{~m}$ drift. Freshwater equivalent groundwater heads $h_{f}$ (Figures 2.3d and f) were estimated from the measurements as,

$$
h_{f}=\frac{p}{\rho_{f} g}+z_{s}
$$

where $p(\mathrm{~Pa})$ is the measured pressure, $\rho_{f}\left(\mathrm{~kg} / \mathrm{m}^{3}\right)$ is the density of freshwater, $g\left(\mathrm{~m} / \mathrm{s}^{2}\right)$ is the gravitational constant, and $z_{s}(\mathrm{~m})$ is the measured elevation of the sensor (relative to NAVD88).

Ocean water levels and temperature were measured every 6 min with a NOAA tide gauge (ID 8651371) in about $6 \mathrm{~m}$ depth at the end of the FRF pier. Tides were semi-diurnal with range $\sim 1 \mathrm{~m}$ and storm surge was up to $\sim 1 \mathrm{~m}$. Significant wave heights $\left(H_{s}, 4\right.$ times the standard deviation of sea-surface elevation fluctuations in the frequency range from 0.05 to $0.30 \mathrm{~Hz}$ ) recorded every $30 \mathrm{~min}$ in 26-m water depth (NDBC Station 44100) ranged from near 0 to $6 \mathrm{~m}$ (Figure 2.3b), with an average of about $1 \mathrm{~m}$. Breaking wave-driven setup (Longuet-Higgins \& Stewart, 1964) of the shoreline water levels is estimated to be 0.2 times the offshore significant wave height (Guza \& Thornton, 1981; Nielsen, 1988; Raubenheimer et al. 2001), roughly consistent with observations from a LIDAR on the dune near the northern transect. Shoreline water levels are estimated as the sum of the ocean water level (including tides and surge) and the setup. 
Precipitation (Figure 2.3a) was recorded every 10 min using a set of 3 rain gauges. Data from the gauges is uncertain during extreme rainfall rates $(>0.03 \mathrm{~m} / \mathrm{hr})$, which only occurred once (during Hurricane Matthew, Oct. 2016). Sound level data was measured every 10 minutes in 2-m water depth with a seafloor-mounted pressure gauge in 2014-2015 (ID 601) and with a radar waterlevel sensor in 2016 (ID CS05). Tides are negligible in the sound, but winds can drive rapid $\sim 1 \mathrm{~m}$ water-level changes (Figure 2.3e). Low sound water levels typically occur during the winter months (Figure 2.3e), and often are coincident with high ocean water levels driven by winter storms. Air temperature data was measured approximately every 30 minutes at Currituck County Regional Airport (NOAA ID 72362603737), located on the mainland $~ 30 \mathrm{~km}$ from the FRF.

The FRF surveys the nearshore bathymetry monthly from the base of the dune to approximately $950 \mathrm{~m}$ offshore, including the region offshore of both well transects. In addition, during Hurricane Joaquin (Oct 6-10 2015), a Riegl terrestrial lidar scanner was mounted on the FRF pier and collected 22 hourly 3-D topographic profiles of the dune along $500 \mathrm{~m}$ of the shoreline at a $0.25 \mathrm{~cm}$ resolution (Brodie et al., 2015) near the southern well transect. The pier lidar scanner also obtained dune surveys during Hurricane Hermine (Sep 2016). Dune profiles (elevation versus cross-shore distance) are estimated from each topographic survey by averaging over $10 \mathrm{~m}$ alongshore, centered at the alongshore location of the southern transect. A second Riegl terrestrial lidar scanner was deployed on the dune about $50 \mathrm{~m}$ south of the north transect and collected hourly cross-shore dune and beach profiles during Hurricane Joaquin. 


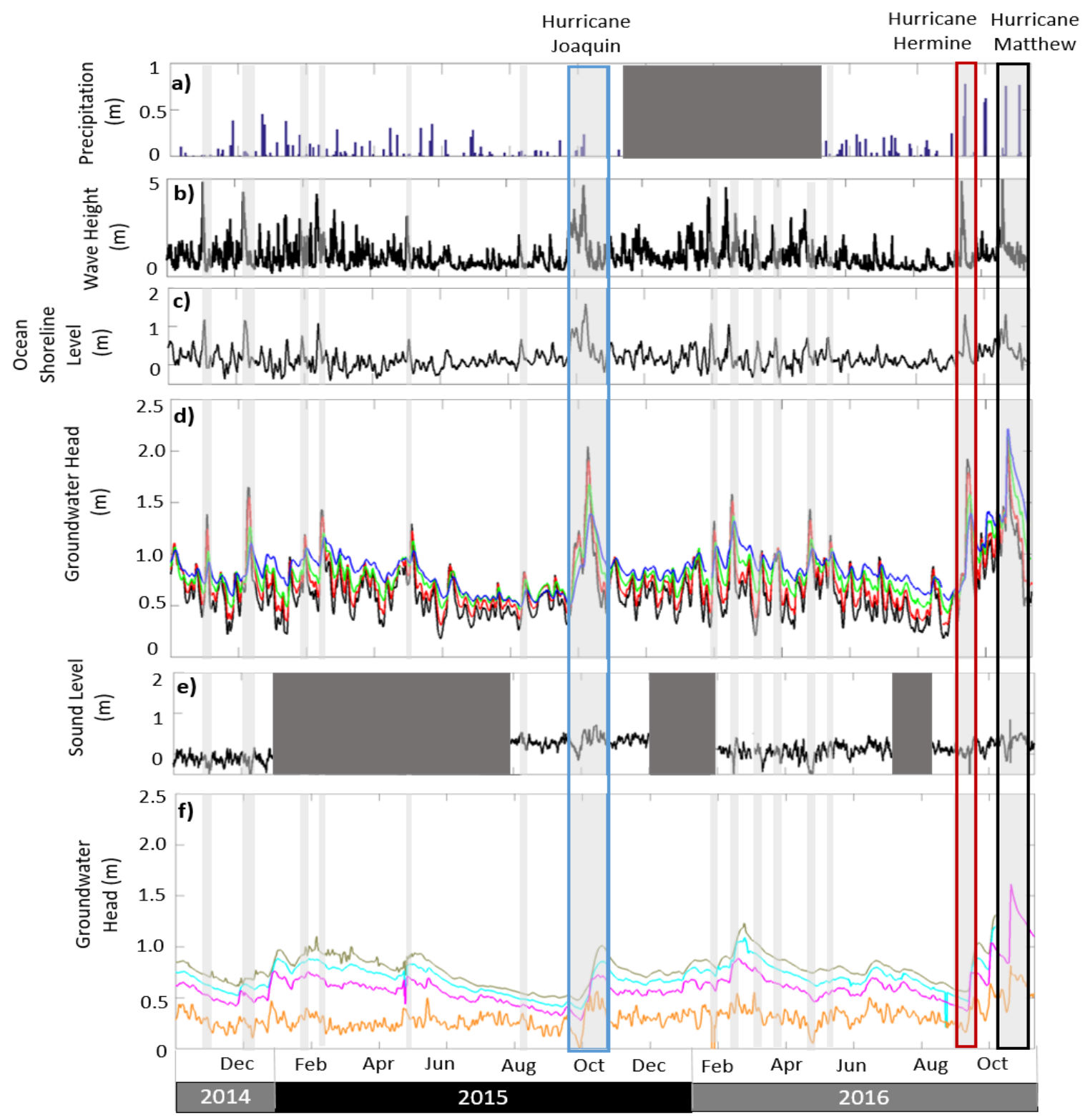

Figure 2.3: a) Precipitation, b) significant wave height, c) 36-hr avg. ocean water level estimated at the shoreline (surge and setup) d) 36-hr. average freshwater equivalent groundwater head on the ocean-side of the island (s0, s30, s95, s160 m, black, red, light green, blue curves), e) sound level, and f) 36-hr average freshwater equivalent groundwater head on the sound side of the island (s310, s400, s450, s550 dark green, teal, magenta, orange) versus time. Colored boxes identify periods with impacts from Hurricanes Joaquin (blue, Oct. 2015), Hurricane Hermine (red, Sept 2016) and Matthew (black, Oct. 2016). Grey vertical bars indicate the 15 storms during the 2-yr period. Dark grey boxes indicate times when no data were available. 


\subsection{Results}

\subsubsection{Cross-island head gradients}

Ocean storms are defined as events with combined 36-hr averaged (de-tided) surge and setup exceeding $0.65 \mathrm{~m}$ (shaded grey bars, Figure 2.3). Fifteen ocean storms were observed during the 2-year data record, including 3 hurricanes that passed offshore of Duck, NC (Hurricanes Joaquin Oct. 2015 (blue box, Figure 2.3), Hermine (red box, Figure 2.3) and Matthew Oct. 2016 (black box, Figure 2.3)). With the exception of Hurricane Matthew, there was little rain $(<5 \mathrm{~cm})$ during the ocean storms.

Gradients in the groundwater head change directions during storms on the ocean side of the island. During calm wave conditions, head levels mid-island are higher than those near the ocean, suggesting ocean-side groundwater flow is directed toward the ocean (e.g., Figure 2.3c compare blue with green, red, and black curves in May-July 2015, and Figure 2.4 solid black curve). Ocean-storm-driven increases in the groundwater head under the dune ranged from 1 to 2 m (Figure 2.3c, gray vertical bars). Consequently, during ocean storms, the seaward well has a higher head level than the mid-island wells, suggesting the ocean-side groundwater flow is directed inland (Figure 2.3c \& dashed red curve in Figure 2.4). Wind-driven increases in the sound water level (Figure 2.3d) cause increased heads on the sound side of the island (Figure 2.3e). However, these small $(<0.5 \mathrm{~m})$ head increases may reduce the sound-side cross-island head gradients, but rarely change the direction of the gradients (Figure 2.3e, compare olive curve with the cyan, magenta, and orange curves). Groundwater head fluctuations observed at the northern well transect (not shown) were similar in magnitude and duration to those measured at the corresponding well location in the southern well transect. 


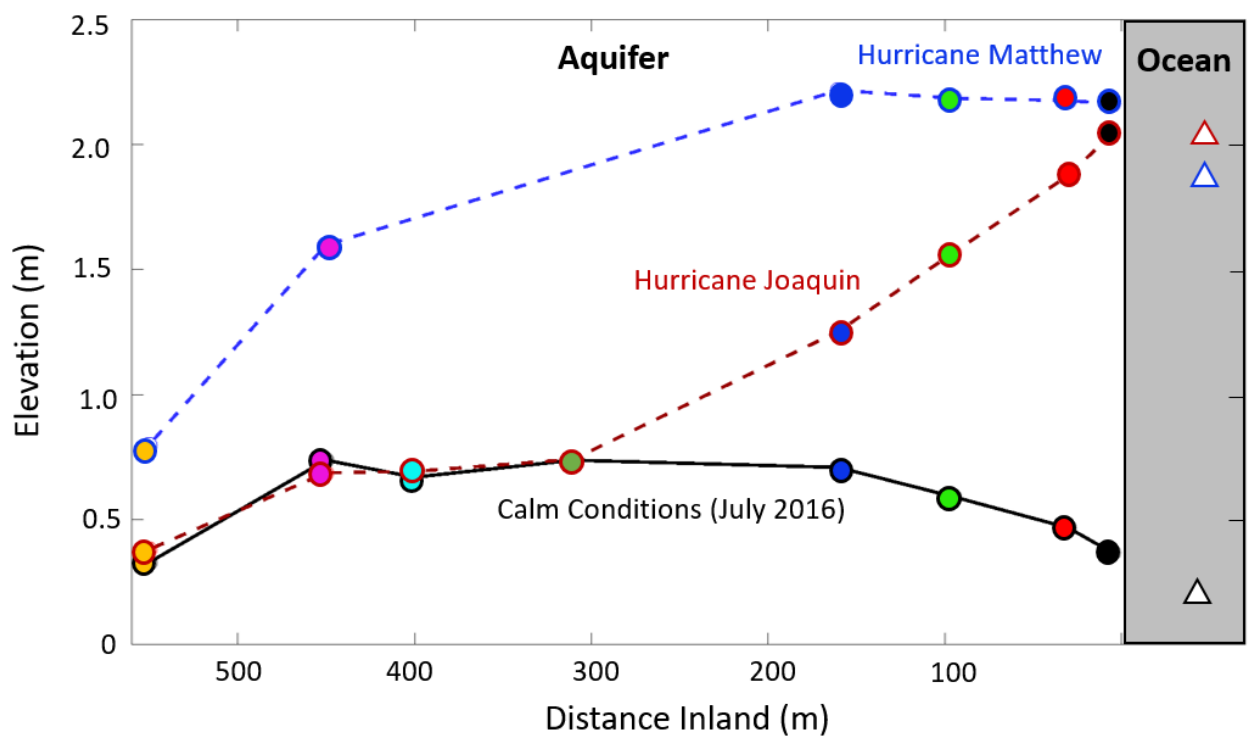

Figure 2.4: Elevation of the shoreline (triangles, color corresponds to periods below) and equivalent groundwater heads (filled circles, colors correspond to colors of symbols in (a)) versus cross-shore distance from the ocean-side wells for calm conditions in July 2016 (black perimeters connected by black lines), Hurricane Joaquin (red perimeters connected by red dashed lines), and Hurricane Matthew (blue perimeters connected by blue dashed line). During Hurricane Matthew the mid-island wells were not operational, but heads at all ocean-side wells increased -.6 to $0.9 \mathrm{~m}$ roughly simultaneously in response to $\sim 0.2$ to $0.3 \mathrm{~m}$ rainfall.

As Hurricane Matthew approached the study site, infiltration from heavy precipitation (> $0.1 \mathrm{~m}$ ), possibly including ponding in low-lying areas, and increasing ocean and sound water levels combined to result in a near simultaneous 0.6 to $0.9 \mathrm{~m}$ increase in groundwater level at most well locations (Figure 2.3c,e), resulting in little gradient between the head levels at the four ocean-side wells in the southern transect (Figure 2.4). The rapid rise in water level at inland sensors was primarily caused by rainfall. However, owing to the additional surge-driven increase on the oceanside of the island, the cross-island groundwater head gradient suggests that flows are still directed toward the sound during and following the storm. The difference in the cross-island head profile 
resulting from combined surge and precipitation processes likely affects the post-storm recovery time of the groundwater heads.

\subsubsection{Upper saline plumes}

At the beginning of the observation period (Oct 2014) and during periods of small ocean waves, the groundwater is stably stratified under and behind the dune, with predominantly fresh groundwater (<5 PSU) at the upper sensors ( -1 m NAVD88) and salinity increasing downwards to 23 PSU at the deepest sensors (Figure 2.5b and c). During several ocean storms, high salinity plumes (>20 PSU, Figure 2.5b, centered at $-3 \mathrm{~m}$, outlined in magenta) penetrate into the groundwater. The USP observed during these events is a tracer of the ocean water that infiltrated into the aquifer over the course of the storm. When a plume is present, the salinity measured at the two deepest sensors (-12 and $-15 \mathrm{~m}$ ) becomes 1 to 2 PSU fresher, possibly because the salt water wedge is depressed by the weight of the denser saltwater in the plume, similar to the offshore movement of the wedge when the USP deepens during storms (Kuan et al., 2012; Xin et al., 2010).

Throughout 2 years of observations (Oct 2014-Oct 2016) there were 8 instances when the USP infiltrated under the dune (Figure 2.5b). Plume durations ranged from 13 hours to 19 days, maximum salinities within the plume ranged from 23 to 32 PSU, and the vertical extent of the plumes ranged from 2 to $6 \mathrm{~m}$. All of the plumes at s0 initially were observed at approximately -3 m depth (NAVD88). Only one USP was observed from Nov 2014-Sep 2015, and 7 plumes were observed from Nov 2015- Sep 2016, despite comparable offshore wave conditions during both seasons. The magnitude of the USP observed under the dune is not correlated with the duration or 
the magnitude of the increase in the shoreline water level, likely at least partly owing to changes in beach topography (see Section 3.3).
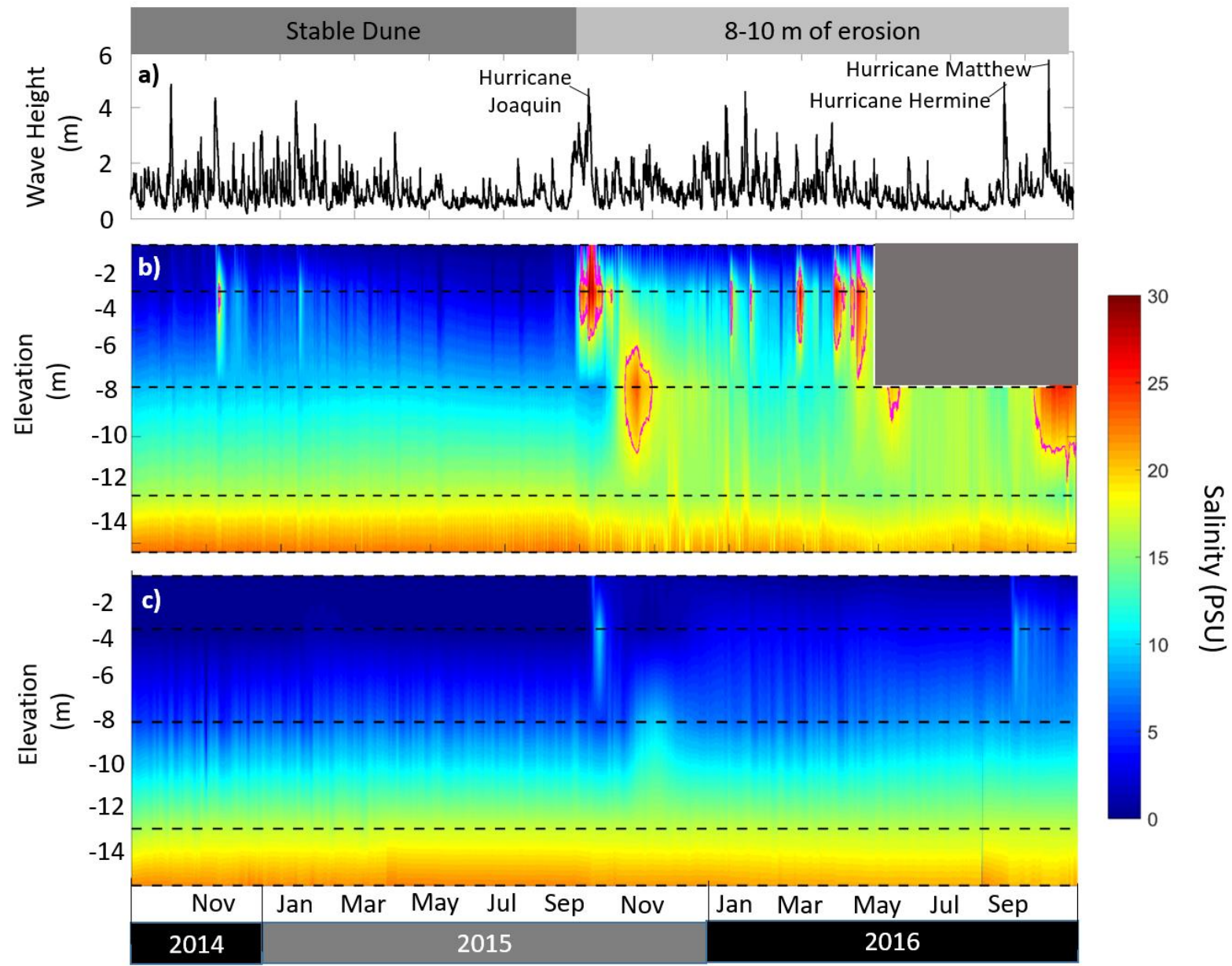

Figure 2.5: a) Significant wave height (black curve, measured at the $26 \mathrm{~m}$ wave buoy) and depth dependence of salinity (colors, scale on the right) b) under the dune (s0) and c) 30-m inland of the dune (s30) along the southern transect versus time. Following large wave events high salinity (red) plumes are observed in the shallow groundwater $(<6 \mathrm{~m})$. The boundary of the USP is estimated as the 20 PSU contour (magenta curves). The horizontal black dashed lines in panels $b$ and $\mathrm{c}$ mark the 5 sensor elevations. The dark grey box in panel $\mathrm{b}$ indicates a sensor outage at $-3 \mathrm{~m}$.

Hurricane Joaquin generated the plume with the longest duration and highest measured salinities. Three days after the peak of Hurricane Joaquin, a shallow saline plume is detected $30 \mathrm{~m}$ inland of the dune (Figure 2.5c). Approximately one month after the shallow saline plume had 
dissipated at s0, another plume of high salinity water is detected deeper in the aquifer at $-7 \mathrm{~m}$ at both s0 (Figure 2.5b) and s30 (Figure 2.5c). No other storm event took place between the dissipation of the plume in the shallow groundwater and the arrival of the deeper plume, and thus the deeper plume also may be a signal of the ocean water that infiltrated during Hurricane Joaquin. Prior to the Nor'easter and Hurricane Joaquin, the salinity measured at $-7 \mathrm{~m}$ was consistently $\sim 9$ PSU. After the dissipation of the deep plume, the salinity at $-7 \mathrm{~m}$ is $\sim 15$ PSU when there is no USP present. These observations suggest large storms can drive salt inland, and the high salinities can persist for several months. Additional measurements or numerical simulations are needed to characterize the temporal evolution of the USP and the thickness of the mixed layer above the salt wedge.

Groundwater temperatures under the dune range from about 15 to $20 \mathrm{C}$, whereas ocean water temperatures range from near 0 to about $30 \mathrm{C}$ (Figure 2.6). Thus, during the fall when ocean water temperatures are warm, storm events (peaks in Figure 2.6a) and the upper saline plumes (Figure 5c) are associated with plumes of warm groundwater (Figure 2.6c, red regions). In contrast, during the winter and spring when ocean water temperatures are relatively cold, the upper saline plumes are associated with intrusion of cold water (Figure 2.6c, dark blue streaks centered at -3 m depth in Apr - Jun 2016). These temperature signatures also can be used to track ocean water that infiltrates into the aquifer. 

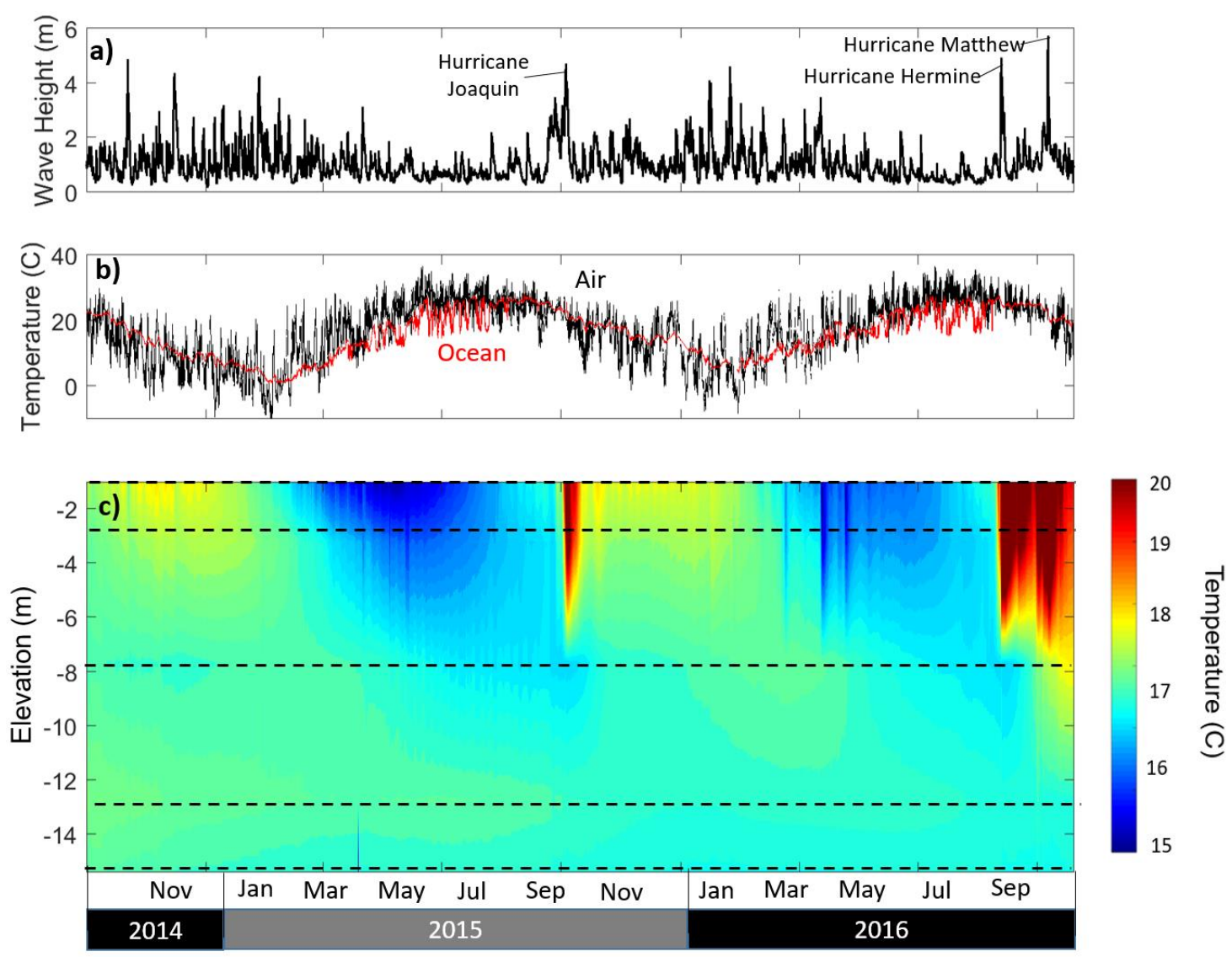

Figure 2.6: a) Significant wave height (black curve, measured at the $26 \mathrm{~m}$ wave buoy), b) air (black curve) and ocean (red curve) temperature, and c) elevation-dependent groundwater temperature (colors, scale on the right) measured under the dune on the south well transect ( $\mathrm{s} 0)$ versus time. The black dashed lines in panel c mark the 5 sensor elevations.

At the northern well transect, only 3 plumes are observed under the dune between Apr 2015 and Oct 2016 (Figure 2.7b). The maximum salinities ( 15 PSU) also are smaller than those recorded at the southern transect. At the north well site, the high salinity water is measured at the upper $(-1 \mathrm{~m})$ sensor prior to the $-3 \mathrm{~m}$ sensor for all 3 events. Similar to the southern transect, Hurricane Joaquin generated the plume with the longest duration and highest measured salinity, and three days after the storm a plume is detected inland of the dune at the n20 well (Figure 2.7c). Cross-shore variations in beach topography likely contribute to the difference in plume behavior 
observed at the northern and southern well transects. Differences in plume behavior also could result from alongshore variations in sediment composition or 3-D circulation effects.
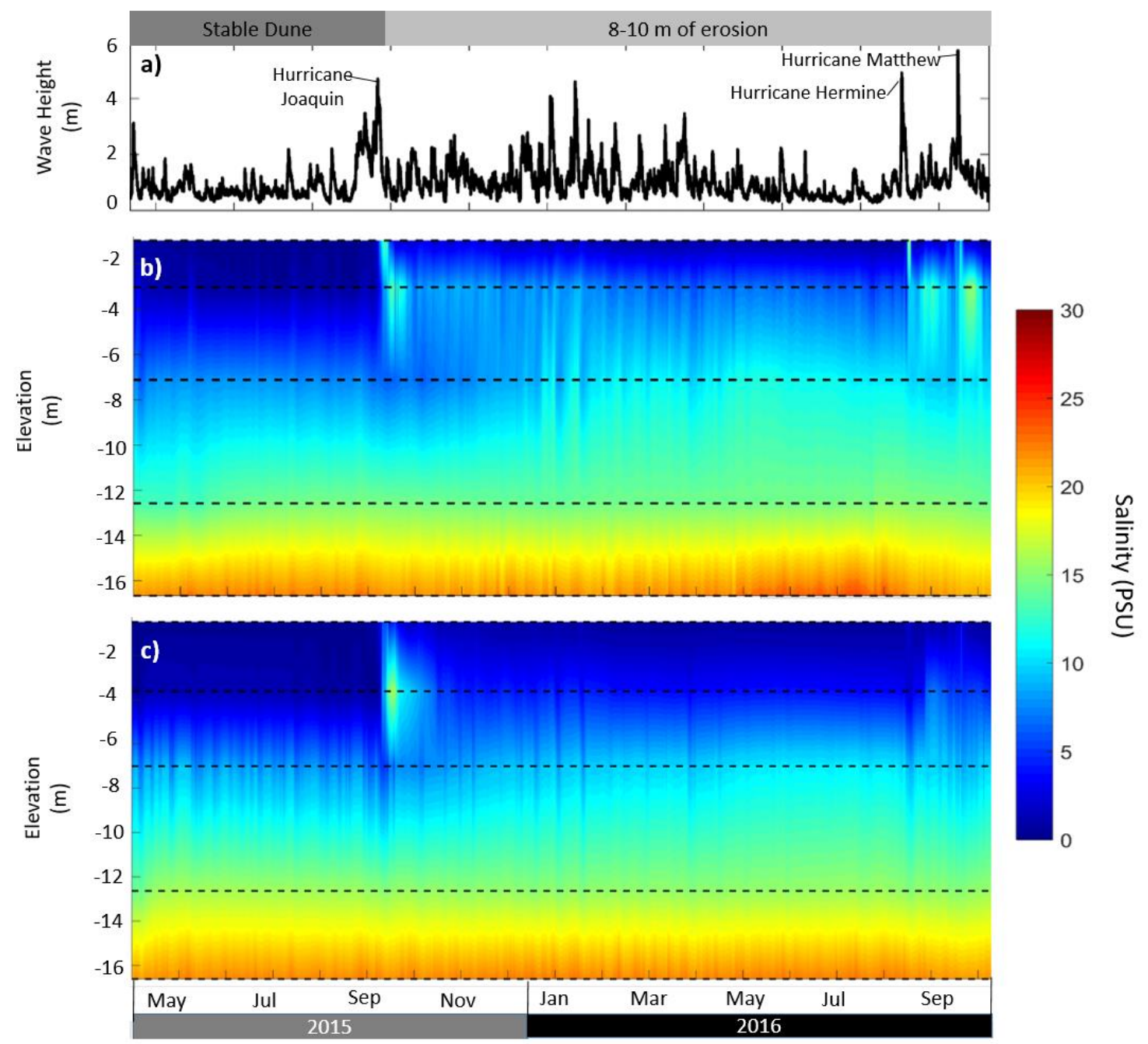

Figure 2.7: a) Significant wave height (black curve, measured at $26 \mathrm{~m}$ wave buoy) and depth dependence of salinity (colors, scale on the right) b) under the dune (n0) and c) 20-m inland of the dune (n20) along the northern transect versus time. Following large wave events high salinity (teal) plumes are observed in the shallow groundwater $(<6 \mathrm{~m})$. The horizontal black dashed lines in panels $b$ and $c$ mark the 5 sensor elevations.

Previous observational studies and numerical simulations with high inland heads (so that groundwater flow always is towards the ocean) suggest the USP is confined to the intertidal (Abarca et al., 2013; Heiss \& Michael, 2014; Robinson et al., 2007ab, 2014). However, the 
simulations showed that the horizontal extent of the USP is larger when the inland freshwater head is lower, and thus the seaward gradient in heads is weaker (Heiss \& Michael, 2014; Robinson et al., 2014). Here, saline plumes often are detected under the dune during and following storms (Figures 2.5, 2.6, and 2.7), suggesting the high groundwater heads under the dune and the inland decrease of the groundwater heads during storms (Figure 2.4) may drive the salt water that infiltrates into the aquifer inland.

\subsubsection{Influence of beach topographic evolution on the USP}

Between Oct 2015 and Sep 2016, the dune face in front of the southern well transect eroded inland approximately $8 \mathrm{~m}$ (Figure 2.8, compare position of the solid blue curve to dashed red curve), whereas the dune face at the northern transect was roughly stable (e.g., Figure 2.9a shows negligible erosion during Hurricane Joaquin). Most of the dune erosion occurs during large wave events that generate runup that can reach the base of the dune. For example, the position of the dune in front of the southern well transect receded several meters during both Hurricane Joaquin and Hurricane Hermine (Figure 2.8). As the dune erodes, the runup and seawater infiltration can extend farther landward. The increase in the number of plumes observed in 2015 and 2016 relative to 2014 (Figures $2.5 \mathrm{~b}$ and 2.6b) may be owing to the long-term erosion of the dune. 


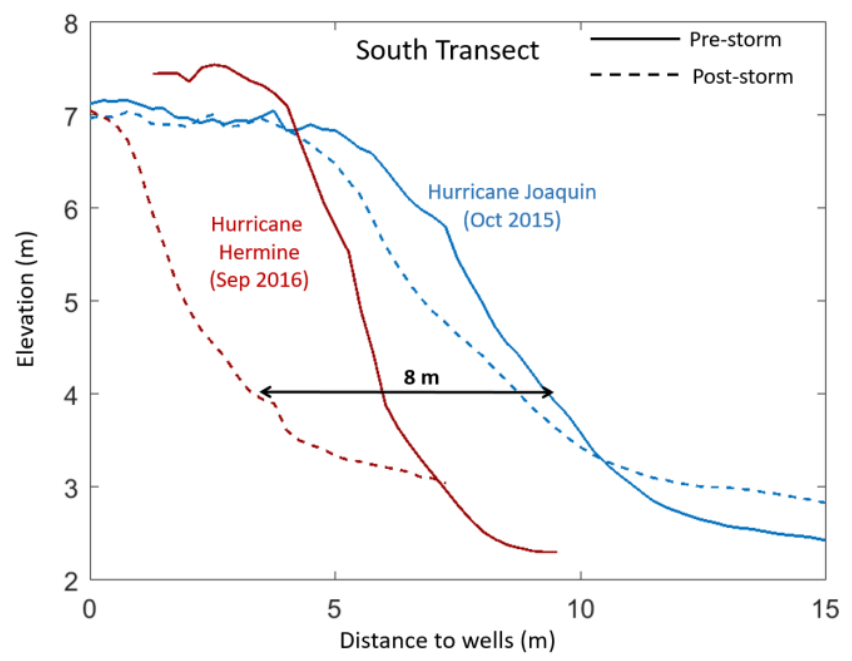

Figure 2.8: Beach topography vs. cross-shore distance ( $x=0 \mathrm{~m}$ at s0, and positive offshore) near the south well transect before (solid curves) and after (dashed curves) Hurricanes Joaquin (blue, Oct 2015) and Hermine (red, Sep 2016). Prior to Hurricane Joaquin in Oct 2015 the position of the dune face was approximately constant.

The higher salinity and frequency of plumes at $\mathrm{s} 0$ compared with those at $\mathrm{n} 0$ (compare Figure $2.5 \mathrm{~b}$ with Figure $2.7 \mathrm{~b}$ ) may be related to differences in the dune and beach geometry. For example, in Oct 2015 the dune face at the southern transect is nearly vertical (Figure 2.9b) and the upper beach $(2<z<3 \mathrm{~m})$ is nearly flat. In contrast, at the north well transect the dune crest is lower, the dune face has a gentler slope, and the upper beach is slightly steeper (Figure 2.9a,c). During Hurricane Joaquin, the dune face and crest eroded $2.5 \mathrm{~m}$ landward near s0, and eroded more than $5.0 \mathrm{~m}$ about $60 \mathrm{~m}$ north of $\mathrm{s} 0$ (not shown), whereas the dune and upper beach eroded less than $1 \mathrm{~m}$ near the north wells (Figure 2.9a). The (subaqueous) beach slope below mean sea level (elevation $\sim 0 \mathrm{~m}$ NAVD88) steepened from $\sim 0.09$ to 0.11 at both locations during the storm. Most of the dune erosion occurred between Oct 04 and Oct 05, 2015, coinciding with the largest offshore wave heights (blue box, Figure 2.3a). 

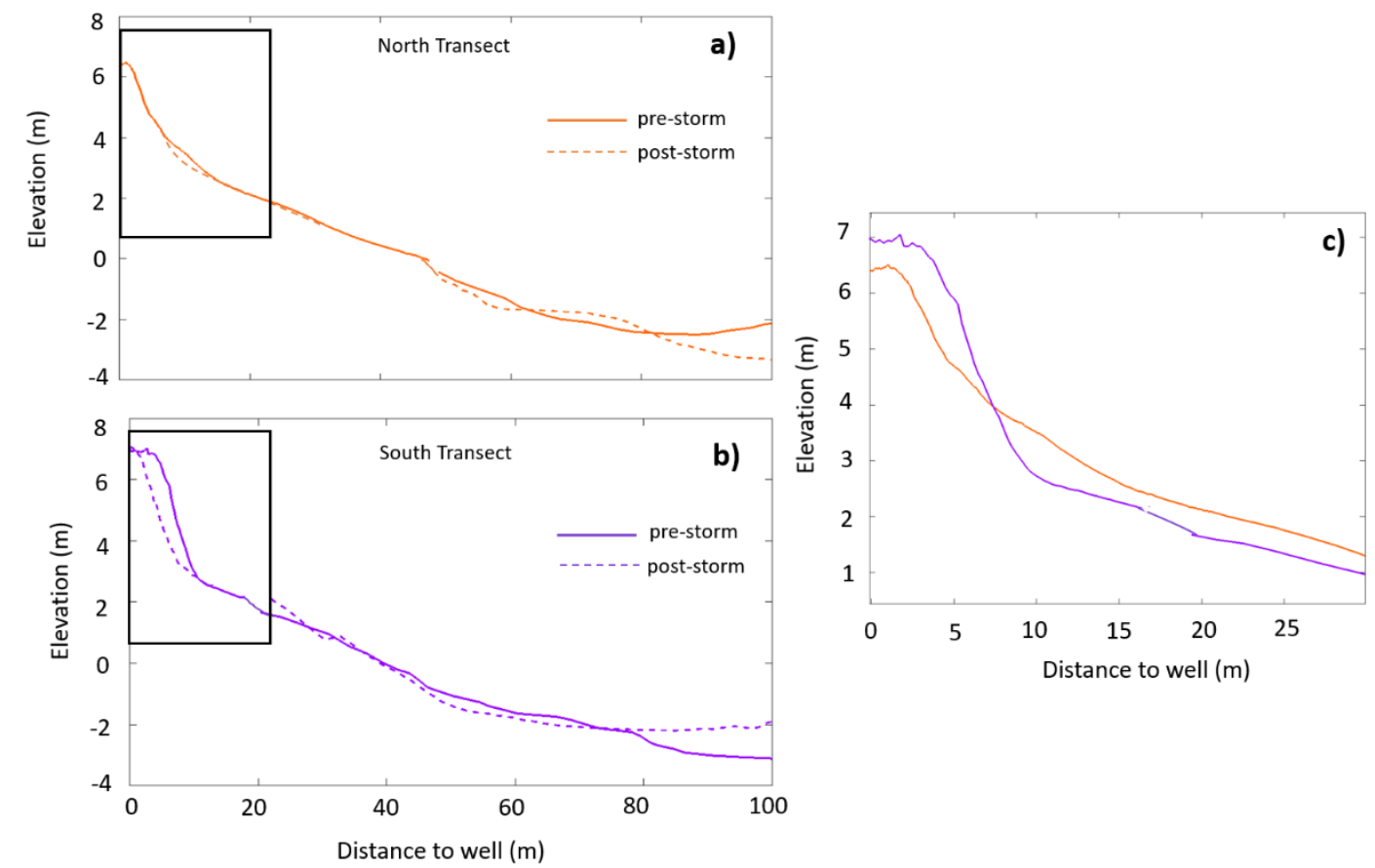

Figure 2.9: Beach topography vs. cross-shore distance ( $x=0 \mathrm{~m}$ at $\mathrm{s} 0$ and $\mathrm{n} 0$, respectively, and positive offshore) near the a) northern and b) southern wells prior to (solid curves) and following Hurricane Joaquin (dashed curves) in Oct 2015. c) Pre-storm beach profiles near the dune at the northern (orange) and southern (purple) transects vs. cross-shore distance. The black boxes in a and $\mathrm{b}$ indicate the region of the pre-storm beach plotted in $\mathrm{c}$.

The highest ocean water levels on the beach often are parameterized by $\mathrm{R}_{2} \%$, the elevation exceeded by fewer than $2 \%$ of the wave runups. An empirical parameterization (Stockdon et al. 2006, eqn. 19) that is a function of foreshore beach slope, wave height, and wave period, was used to estimate maximum ocean water levels during Hurricane Joaquin (Figure 2.10a). Owing to the different topographies at the southern and northern transects, the estimated $\mathrm{R}_{2} \%$ often was $5 \mathrm{~m}$ closer to s0 than to $\mathrm{n} 0$ at high tide (Figures $2.10 \mathrm{~b}$ and $\mathrm{c}$ ) as the storm intensity increased from Oct 01 to Oct 04 . In particular, owing to the flat upper beach at the southern site, the maximum wave runup often reached the toe of the steep dune face (where the slope changes rapidly, $x \sim 5$ to $10 \mathrm{~m}$ ). In contrast, the more steeply sloping upper beach on the northern transect prevented the waves from reaching the dune, except at the peak of the storm (Figure 2.10a, $\mathrm{R}_{2} \%=4 \mathrm{~m}$ and Figure 2.10b, 
orange and purple curves overlay, and Figure 2.10c, difference in the distance to wells is near 0 on Oct 05).

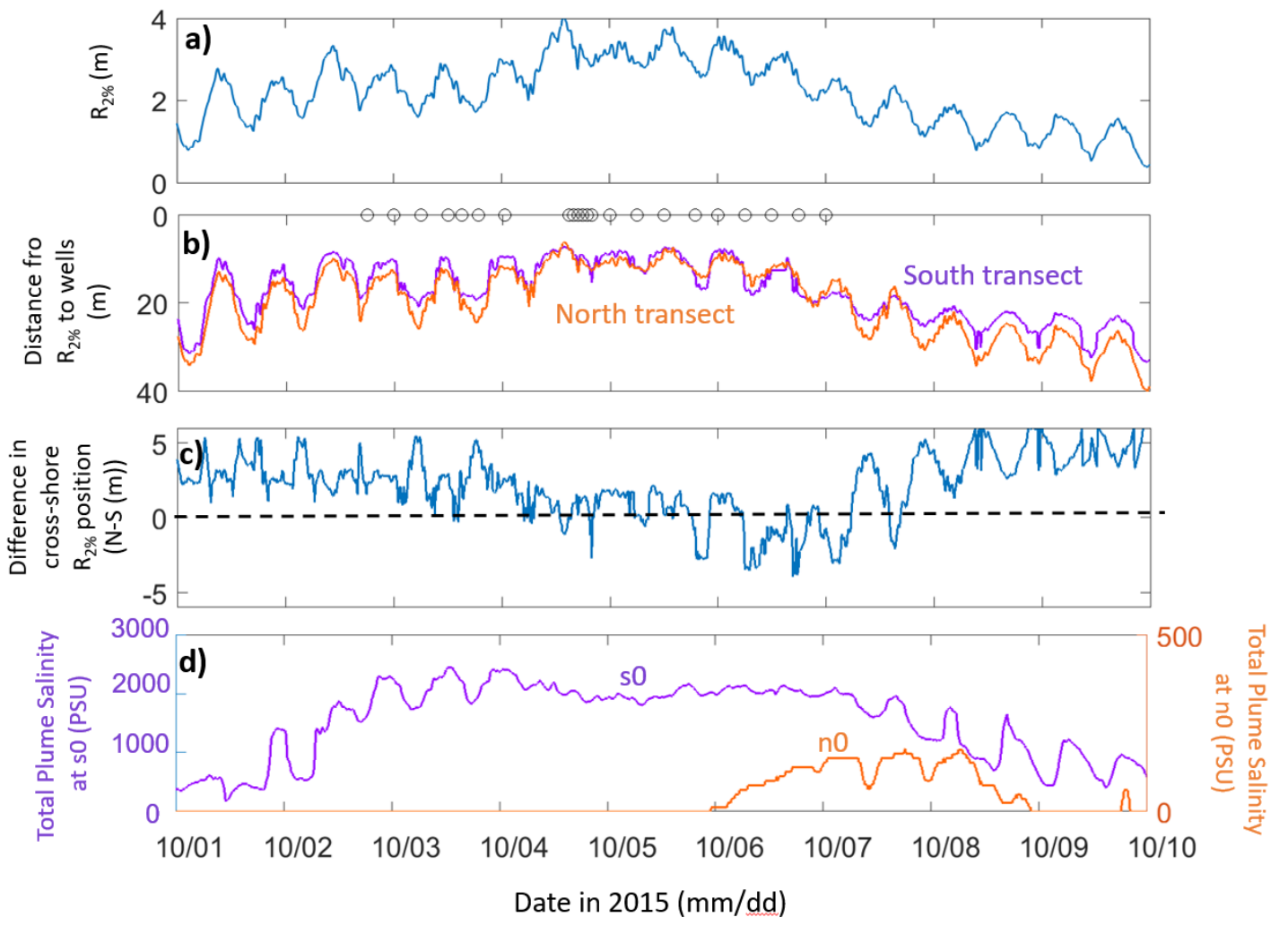

Figure 2.10: a) $\mathrm{R}_{2} \%$, b) distance between the $2 \%$ runup and the groundwater wells at s0 (purple curve) and $\mathrm{n} 0$ (orange curve), c) difference in cross-shore position of $\mathrm{R}_{2} \%$ between the southern and northern transects vs. date in Oct 2015, and d) total plume salinity at the south wells (purple curve, left axis) and north wells (orange curve, right axis). The beach topography was surveyed on the southern transect at the times indicated by the open circles in panel c.

The "total plume salinity", the salinity within the 15 PSU contour summed over elevation and time (Figures $2.5 \mathrm{~b}$ and $2.7 \mathrm{~b}$ ), which is a proxy for the USP magnitude, increases at s0 near the start of the storm on Oct 01 (Figure 2.5a). At n0, The USP does not appear until after the peak of the storm (on Oct 06) and contains less total salt (Figure 2.10d). The smaller magnitude and later arrival of the northern USP relative to that on the southern transect may be owing to the greater 
distance between the ocean waves $\left(\mathrm{R}_{2} \%\right)$ and the dune wells. As in prior studies showing that the beach profiles influences the horizontal and vertical extent of the USP (Evans \& Wilson, 2016; Heiss \& Michael, 2014), differences in plume geometry resulting from the beach topography also may contribute to the difference in the timing and magnitude of the observed USP at the northern and southern locations. Additionally, the effects of the offshore ocean sandbar on the location of wave breaking and the inland excursion of runup and sea water infiltration (Birkemeier et al., 1999), is not accounted for in the runup parameterization. Seasonal differences in the sound water level and precipitation also could contribute to the temporal variability of the plumes.

\subsubsection{Seasonal Temperature}

At $\mathrm{s} 0$, the range in the seasonal fluctuation in the groundwater temperature is roughly $4 \mathrm{C}$ (14-18C, neglecting the strong temperature signals of the plumes) near the aquifer surface and decreases with depth (Figure 2.6c, the temperature range at elevation $=-15 \mathrm{~m}$ is $<1 \mathrm{C}$ ). The lag between the seasonal groundwater temperature fluctuation and the air and ocean temperature is about 3 months at -1 m elevation and increases with depth. In contrast, the USP temperature is roughly equal to the ocean temperature, and thus ocean storms can alter both the salinity and temperature of the groundwater under the dune.

On the sound side of the island (s550), the range of the seasonal groundwater temperature fluctuations is 10C (Figure 2.11). Similar to the ocean-side measurements, the range of the seasonal temperature signature decreases with depth, and the fluctuations are $<1 \mathrm{C} 15 \mathrm{~m}$ below the surface. The groundwater temperature at $15 \mathrm{~m}$ depth is about a degree warmer on the sound side than on the ocean side of the island. In contrast to the ocean side of the island, the lag between the seasonal groundwater temperature fluctuation and the seasonal variation in the air and ocean 
temperature on the sound side is only about 0.5 months (Figure 2.11 ). This shorter lag time may be owing to the closer proximity of the sound-side watertable to ground level (the island elevation at $\mathrm{s} 550$ is less than $1 \mathrm{~m}$, whereas the ground elevation at $\mathrm{s} 0$ is about $7 \mathrm{~m} \mathrm{NAVD88),} \mathrm{or} \mathrm{the} \mathrm{closer}$ proximity to the surface water body (during calm conditions the ocean intertidal region is about $40 \mathrm{~m}$ from the dune (Figure 2.9, elevation $=0 \mathrm{~m}$ ), whereas the sound-side wells are only a few meters from the open water.
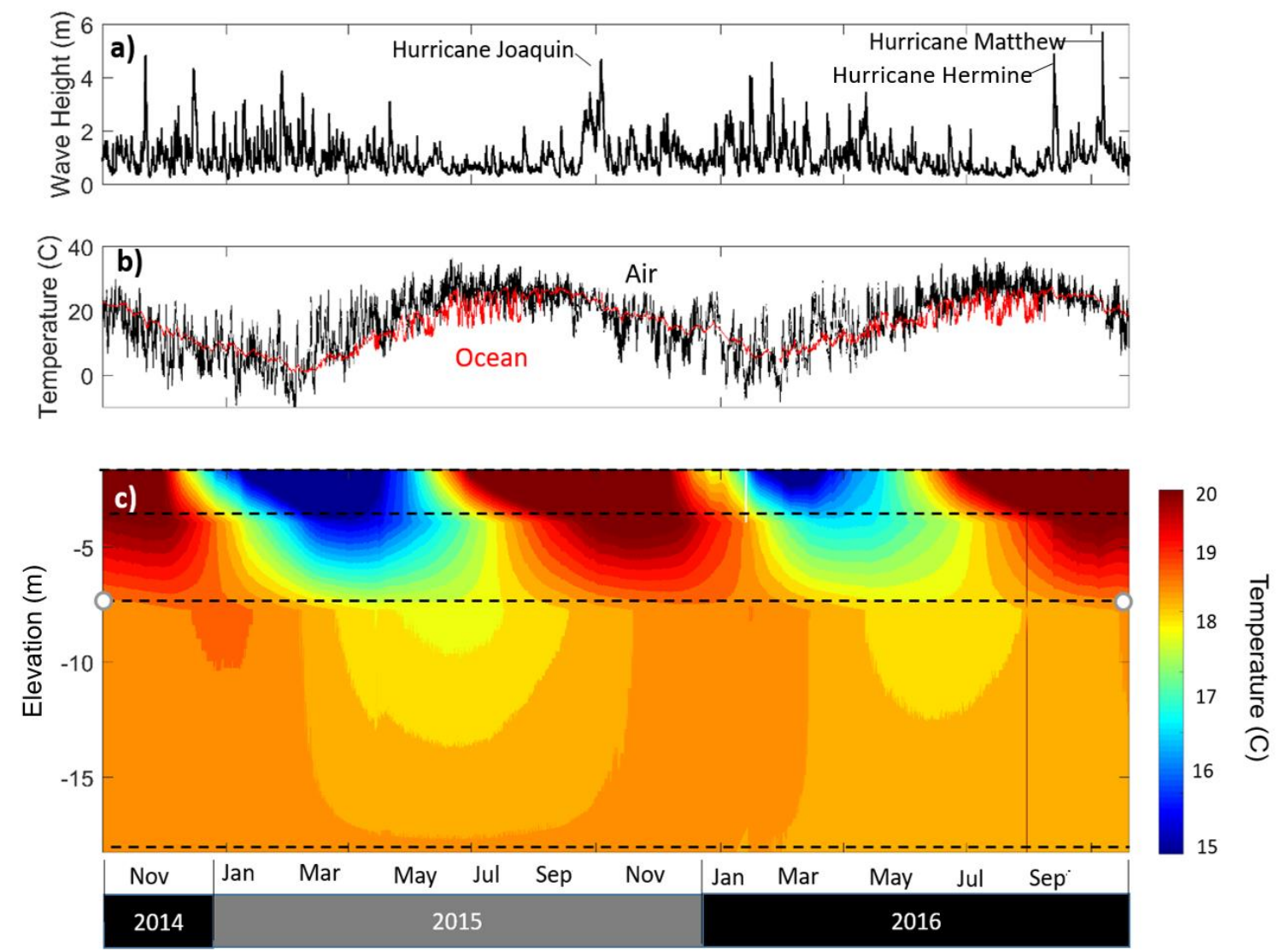

Figure 2.11: a) Significant wave height (black curve, measured at the $26 \mathrm{~m}$ wave buoy), b) air (black curve) and ocean (red curve) temperature, and c) depth-dependent groundwater temperature (colors, scale on the right) measured near the sound on the south well transect (s550) versus time. The horizontal black dashed lines in panel c mark the 4 sensor elevations.

Heat fluxes from the sound and the ocean diffuse inland, and the lag between the nearsurface (averaged between -3 and -7 m elevation) groundwater temperature and the air and ocean 
temperature increases with distance inland from the sound or ocean side (Figure 2.12). At crossshore distance $400 \mathrm{~m}$, the maximum near-surface groundwater temperature occurs close in time with the minimum air and ocean temperatures. Although, no sound temperature measurements were collected, the sound is fresher and shallower than the ocean so will warm and cool more rapidly. Additionally, thermal signals in groundwater respond less rapidly than surface waters to changes in atmospheric temperature, and the time delay depends on the depth of the water table, depth of the measurement, and the thermal diffusivity of the soil (Benz et al., 2018; Taniguchi, 1993; Taylor \& Stefan, 2009). Furthermore, the proximity of the water table to the land surface is similar at distances 95 and $550 \mathrm{~m}$, but the groundwater temperature signals are significantly different (Figure 2.12), supporting the importance of sound and ocean heat diffusion. Therefore, diffusion of heat from the sound likely accounts for warmer temperatures on the sound side of the island, whereas colder ocean temperatures likely damp the atmospherically driven heating on the ocean side of the island (ocean temperatures have a slightly smaller temperature range than air temperatures). Numerical model simulations that incorporate heat fluxes may help to characterize these spatial patterns in temperature. 

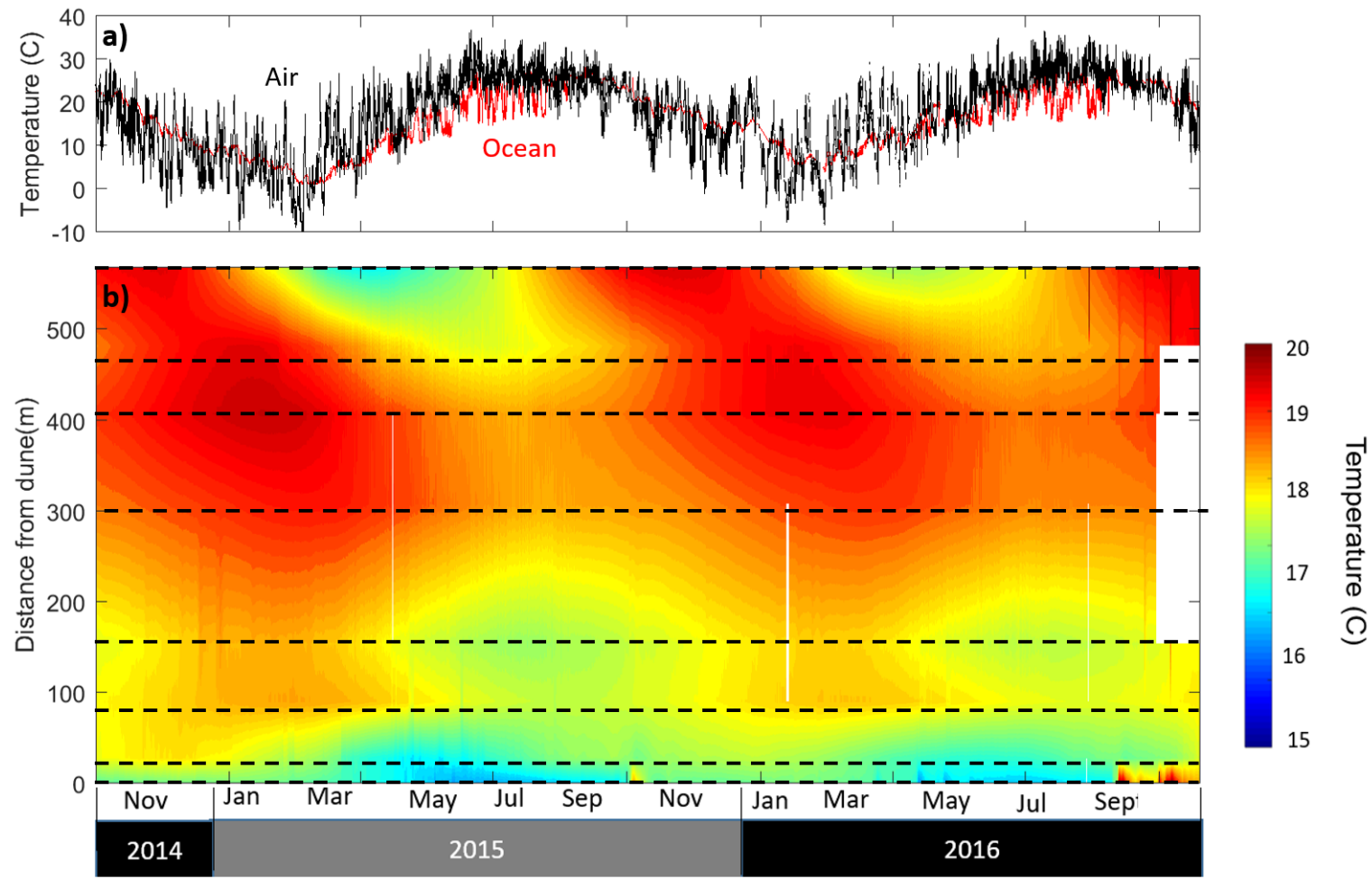

Figure 2.12: a) Air (black curve) and ocean (red curve) temperature and b) depth-averaged (-3 to $-7 \mathrm{~m}$ ) near-surface groundwater temperature (colors, scale on the right) as a function of cross-shore distance and time at the south transect. The horizontal black dashed lines in panel b mark the crossshore positions of the 8 wells.

\subsection{Conclusions}

Interactions between the ocean, the sound, and the coastal aquifer drive the temporal and spatial patterns in groundwater head, temperature, and salinity observed in a North Carolina barrier island aquifer between Oct 2014 and Oct 2016. Infiltration from surge, tides, and waves reverses the direction of the head gradient on the ocean side of the island. Plumes of high salinity (> 20 PSU) water were measured under the ocean dune at $\sim 3 \mathrm{~m}$ depth during and following 9 ocean storms. The plumes are hypothesized to be an inland expansion of the upper saline plume (USP) that often has been described and modeled within the intertidal region. The plume temperatures 
are similar to ocean water temperatures, which are relatively warm (cold) with respect to the groundwater during the fall (spring). Heat exchanges between the aquifer, sound, and ocean also control the spatial pattern of seasonal temperature fluctuations in the aquifer. Beach topography changed significantly, affecting the location of ocean wave runup, and possibly altering the USP structure (consistent with prior work) and inland penetration of the USPs.

\subsection{Acknowledgements}

We thank the USACE CHL-Field Research Facility for ocean and meteorological observations, and Levi Gorrell, Fred Marin, Emmett Krupczak, Suzi Clark, Bill Boyd, Paul Henderson, Heidi Wadman, Jesse McNinch, and Pat Dickhudt for assistance deploying and maintaining the groundwater wells. Funding was provided by the U.S. Coastal Research Program, the National Science Foundation, a National Science Foundation Graduate Research Fellowship, the Woods Hole Oceanographic ISP program, and National Security Science \& Engineering and Vannevar Bush Faculty Fellowships.

\subsection{References}

Abarca, E., Karam, H., Hemond, H., \& Harvey, C. (2013). Transient groundwater dynamics in a coastal aquifer: The effects of tides, the lunar cycle, and the beach profile. Water Resources, 49(5), 2473-2488.

Anderson, W. P. J., \& Lauer, R. M. (2008). The role of overwash in the evolution of mixing zone morphology within barrier islands. Hydrogeology Journal, 16(8), 1483-1495.

Appelo, C. A. J. (1994). Cation and proton exchange, $\mathrm{pH}$ variations, and carbonate reactions in a freshening aquifer. Water Resources Research, 30(10), 2793-2805. https://doi.org/10.1029/94WR01048

Befus, K. M., Barnard, P. L., Hoover, D. J., Finzi Hart, J. A., \& Voss, C. I. (2020). Increasing threat of coastal groundwater hazards from sea-level rise in California. Nature Climate Change, 10, 946-952. 
Befus, K. M., Cardenas, M. B., Erler, D. V., Santos, I. R., \& Eyre, B. D. (2013). Heat transport dynamics at a sandy intertidal zone. Water Resources Research, 49(6), 3770-3786. https://doi.org/10.1002/wrcr.20325

Benz, S. A., Bayer, P., Winkler, G., \& Blum, P. (2018). Recent trends of groundwater temperatures in Austria. Hydrology and Earth System Sciences, 22(6), 3143-3154. https://doi.org/10.5194/hess-22-3143-2018

Birkemeier, W., Nicholls, R., \& Lee, G. (1999). Storms, storm groups and nearshore morphologic change. Coastal Sediments, 1109-1122.

Boss, S. K., Hoffman, C. W., \& Cooper, B. (2002). Influence of fluvial processes on the quaternary geologic framework of the continental shelf, North Carolina, USA. Marine Geology, 183(1-4), 45-65. https://doi.org/10.1016/S0025-3227(01)00253-5

Boufadel, M. C. (2000). A mechanistic study of nonlinear solute transport in a groundwatersurface water system under steady state and transient hydraulic conditions. Water Resources Research, 36(9), 2549-2565. https://doi.org/10.1029/2000WR900159

Boufadel, M. C., Li, H., Suidan, M. T., \& Venosa, A. D. (2007). Tracer studies in a laboratory beach subjected to waves. Journal of Environmental Engineering, 133(7), 722-732. https://doi.org/10.1061/(ASCE)0733-9372(2007)133:7(722)

Boufadel, M. C., Xia, Y., \& Li, H. (2011). Modeling solute transport and transient seepage in a laboratory beach under tidal influence. Environmental Modelling \& Software, 26(7), 899912. https://doi.org/10.1016/j.envsoft.2011.02.005

Bouwer, H., \& Rice, R. C. (1976). A slug test for determining hydraulic conductivity of unconfined aquifers with completely or partially penetrating wells. Water Resources Research, 12(3), 423-428. https://doi.org/10.1029/WR012i003p00423

Brodie, K. L., Raubenheimer, B., Elgar, S., Slocum, R. K., \& McNinch, J. E. (2015). Lidar and pressure measurements of inner-surfzone waves and setup. Journal of Atmospheric and Oceanic Technology, 32(10), 1945-1959.

Brown, D. L., Narasimhan, T. N., \& Demir, Z. (1995). An evaluation of the Bouwer and Rice method of slug test analysis. Water Resources Research, 31(5), 1239-1246. https://doi.org/10.1029/94WR03292

Butler, J. J., McElwee, C. D., \& Liu, W. (1996). Improving the quality of parameter estimates obtained from slug tests. Groundwater, 34(3), 480-490. https://doi.org/10.1111/j.17456584.1996.tb02029.x 
Cartwright, N., Nielsen, P., \& Li, L. (2004). Experimental observations of watertable waves in an unconfined aquifer with a sloping boundary. Advances in Water Resources, 27(10), 9911004. https://doi.org/10.1016/J.ADVWATRES.2004.08.006

Charette, M. A., \& Sholkovitz, E. R. (2002). Oxidative precipitation of groundwater-derived ferrous iron in the subterranean estuary of a coastal bay. Geophysical Research Letters, 29(10), 85-1-85-4. https://doi.org/10.1029/2001GL014512

Charette, M. A., \& Sholkovitz, E. R. (2006). Trace element cycling in a subterranean estuary: Part 2. Geochemistry of the pore water. Geochimica et Cosmochimica Acta, 70(4), 811826. https://doi.org/10.1016/j.gca.2005.10.019

Colbert, S. L., Berelson, W. M., \& Hammond, D. E. (2008). Radon-222 budget in Catalina Harbor, California: 2. Flow dynamics and residence time in a tidal beach. Limnology and Oceanography, 53(2), 659-665. https://doi.org/10.4319/lo.2008.53.2.0659

Constantz, J. (2008). Heat as a tracer to determine streambed water exchanges. Water Resources Research, 44(4). https://doi.org/10.1029/2008WR006996

Elci, A., Molz, F. J., \& Waldrop, W. R. (2001). Implications of Observed and Simulated Ambient Flow in Monitoring Wells. Groundwater, 39(6), 853-862. https://doi.org/10.1111/j.1745-6584.2001.tb02473.x

Elko, N. A., Sallenger, A. H., Guy, K., Stockdon, H. F., \& Morgan, K. L. M. (2002). Barrier Island Elevations Relevant to Potential Storm Impacts: 1. Techniques. US Geological Survey Open File Report, 02-287

Evans, T. B., \& Wilson, A. M. (2016). Groundwater transport and the freshwater-saltwater interface below sandy beaches. Journal of Hydrology, 538, 563-573. https://doi.org/10.1016/j.jhydrol.2016.04.014

Fofonoff, N., Millard, R.C. Jr., 1983. Algorithms for the computation of fundamental properties of seawater. UNESCO Tech. Pap. Mar. Sci..

Gast, R., Elgar, S., \& Raubenheimer, B. (2015). Observations of transport of bacterial-like microspheres through beach sand. Continental Shelf Research, 97, 1-6.

Geng, X., Boufadel, M. C., Xia, Y., Li, H., Zhao, L., Jackson, N. L., \& Miller, R. S. (2014). Numerical study of wave effects on groundwater flow and solute transport in a laboratory beach. Journal of Contaminant Hydrology, 165, 37-52. https://doi.org/10.1016/j.jconhyd.2014.07.001

Guza, R. T., \& Thornton, E. B. (1981). Wave set-up on a natural beach. Journal of Geophysical Research, 86(C5), 4133. https://doi.org/10.1029/JC086iC05p04133 
Heiss, J. W., \& Michael, H. A. (2014). Saltwater-freshwater mixing dynamics in a sandy beach aquifer over tidal, spring-neap, and seasonal cycles. Water Resources Research, 50(8), 6747-6766. https://doi.org/10.1002/2014WR015574

Henderson, R. D., Day-Lewis, F. D., \& Harvey, C. F. (2009). Investigation of aquifer-estuary interaction using wavelet analysis of fiber-optic temperature data. Geophysical Research Letters, 36(6), L06403. https://doi.org/10.1029/2008GL036926

Hvorslev, M.J., 1951. Time lag and soil permeability in ground-water observations, Waterways Experiment Station, Corps of Engineers. U. S. Army, Bull. 36, 49.

Irvine, D. J., Briggs, M. A., Lautz, L. K., Gordon, R. P., McKenzie, J. M., \& Cartwright, I. (2017). Using diurnal temperature signals to infer vertical groundwater-surface water exchange. Groundwater, 55(1), 10-26. https://doi.org/10.1111/gwat.12459

Kalbus, E., Reinstorf, F., \& Schirmer, M. (2006). Measuring methods for groundwater - surface water interactions: A review. Hydrology and Earth System Sciences. Copernicus GmbH. https://doi.org/10.5194/hess-10-873-2006

Kuan, W. K., Jin, G., Xin, P., Robinson, C., Gibbes, B., \& Li, L. (2012). Tidal influence on seawater intrusion in unconfined coastal aquifers. Water Resources Research, 48(2). https://doi.org/10.1029/2011WR010678

Kurylyk, B. L., Bourque, P.A., \& Macquarrie, K. T. B. (2013). Potential surface temperature and shallow groundwater temperature response to climate change: an example from a small forested catchment in east-central New Brunswick (Canada). Hydrol. Earth Syst. Sci, 17, 2701-2716. https://doi.org/10.5194/hess-17-2701-2013

Kurylyk, B. L., Irvine, D. J., \& Bense, V. F. (2019). Theory, tools, and multidisciplinary applications for tracing groundwater fluxes from temperature profiles. Wiley Interdisciplinary Reviews: Water, 6(1), e1329. https://doi.org/10.1002/wat2.1329

Lautier, J. C. (2009). Hydrogeologic Framework and Ground Water Conditions in the North Carolina East Central Coastal Plain.

Lazarus, E. D., \& Murray, A. B. (2011). An integrated hypothesis for regional patterns of shoreline change along the Northern North Carolina Outer Banks, USA. Marine Geology, 281(1-4), 85-90. https://doi.org/10.1016/j.margeo.2011.02.002

Lee, G., Nicholls, R. J., \& Birkemeier, W. A. (1998). Storm-driven variability of the beachnearshore profile at Duck, North Carolina, USA, 1981-1991. Marine Geology, 148(3-4), 163-177. https://doi.org/10.1016/S0025-3227(98)00010-3 
LeRoux, N. K., Kurylyk, B. L., Briggs, M. A., Irvine, D. J., Tamborski, J. J., \& Bense, V. F. (2021). Using heat to trace vertical water fluxes in sediment experiencing concurrent tidal pumping and groundwater discharge. Water Resources Research, 57(2), e2020WR027904. https://doi.org/10.1029/2020WR027904

Levanon, E., Yechieli, Y., Shalev, E., Friedman, V., \& Gvirtzman, H. (2013). Reliable monitoring of the transition zone between fresh and saline waters in coastal aquifers. Groundwater Monitoring \&amp; Remediation, 33(3), 101-110. https://doi.org/10.1111/GWMR.12020

Li., L., Cartwright, N., Nielsen, P., \& Lockington, D. (2004). Response of coastal groundwater table to offshore storms. China Ocean Engineering, 18(3), 423-431.

Longuet-Higgins, M. S., \& Stewart, R. W. (1964). Radiation stresses in water waves: A physical discussion, with applications. Deep-Sea Research, 11, 529-562.

Mallinson, D.J., Smith, C.W., Culver, S.J., Riggs, S.R. \& Ames, D (2010), Geological characteristics and spatial distribution of paleo-inlet channels beneath the outer banks barrier islands, North Carolina, USA. Estuarine, Coastal and Shelf Science, 88(2), 175-189.

Manahan, S., Martin, W. K., \& Guo, W. (1998). Dare County-wide Hydrogeological Study and Groundwater Resource Evaluation. Dare County Water Production Department, Kill Devil Hills, NC.

Meisburger, E. P., Williams, S. J., \& Judge, C. (1989). Physiographic and Geological Setting of the Coastal Engineering Research Center's Field Research Facility. Vicksburg, MS.

Miller, D. C., \& Ullman, W. J. (2004). Ecological Consequences of Ground Water Discharge to Delaware Bay, United States. Ground Water, 42(7), 959-970. https://doi.org/10.1111/j.1745-6584.2004.tb02635.x

Moore, W. W. S. (1999). The subterranean estuary: a reaction zone of groundwater and sea water. Marine Chemistry, 65(1), 111-125. https://doi.org/10.1016/S0304-4203(99)00014-6

Nielsen, P. (1988). Wave setup: A field study. Journal of Geophysical Research, 93(C12), 15643. https://doi.org/10.1029/JC093iC12p15643

Patricola, C. M., \& Wehner, M. F. (2018). Anthropogenic influences on major tropical cyclone events. Nature, 563, 339-346.

Rau, G. C., Andersen, M. S., McCallum, A. M., Roshan, H., \& Acworth, R. I. (2014) Heat as a tracer to quantify water flow in near-surface sediments. Earth-Science Reviews. Elsevier. https://doi.org/10.1016/j.earscirev.2013.10.015 
Raubenheimer, B., Guza, R. T., \& Elgar, S. (1999). Tidal water table fluctuations in a sandy ocean beach. Water Resources Research, 35(8), 2313-2320.

https://doi.org/10.1029/1999WR900105

Raubenheimer, B., Guza, R. T., \& Elgar, S. (2001). Field observations of wave-driven setdown and setup. Journal of Geophysical Research: Oceans, 106(C3), 4629-4638.

https://doi.org/10.1029/2000JC000572

Riggs, S. R., Cleary, W. J., \& Snyder, S. W. (1995). Influence of inherited geologic framework on barrier shoreface morphology and dynamics. Marine Geology, 126(1-4), 213-234. https://doi.org/10.1016/0025-3227(95)00079-E

Robinson, C., \& Li, L. (2004). Effect of tidal oscillations on water exchange and mixing in a coastal aquifer. Developments in Water Science, 55, 1583-1594. https://doi.org/10.1016/S0167-5648(04)80168-0

Robinson, C., Gibbes, B., \& Li, L. (2006). Driving mechanisms for groundwater flow and salt transport in a subterranean estuary. Geophysical Research Letters, 33(3), L03402. https://doi.org/10.1029/2005GL025247

Robinson, C., Li, L., \& Prommer, H. (2007a). Tide-induced recirculation across the aquiferocean interface. Water Resources Research, 43(7). https://doi.org/10.1029/2006WR005679

Robinson, C., Gibbes, B., \& Carey, H. (2007b). Salt-freshwater dynamics in a subterranean estuary over a spring-neap tidal cycle. Journal of Geophysical Research: Oceans, 112(C9)

Robinson, C., Xin, P., Li, L., \& Barry, D. A. (2014). Groundwater flow and salt transport in a subterranean estuary driven by intensified wave conditions. Water Resources Research, 50(1), 165-181. https://doi.org/10.1002/2013WR013813

Rotzoll, K., \& El-Kadi, A. I. (2008). Estimating hydraulic properties of coastal aquifers using wave setup. Journal of Hydrology, 353(1-2), 201-213. https://doi.org/10.1016/J.JHYDROL.2008.02.005

Slomp, C. P., \& Van Cappellen, P. (2004). Nutrient inputs to the coastal ocean through submarine groundwater discharge: controls and potential impact. Journal of Hydrology, 295(1), 64-86. https://doi.org/10.1016/j.jhydrol.2004.02.018

Stockdon, H. F., Holman, R. A., Howd, P. A., \& Jr., A. H. S. (2006). Empirical parameterization of setup, swash, and runup. Coastal Engineering, 53(7), 573-588.

https://doi.org/10.1016/J.COASTALENG.2005.12.005

Stutz, M., \& Pilkey, O. (2011). Open-ocean barrier islands: global influence of climatic, oceanographic, and depositional settings. Journal of Coastal Research, 27(2), 207-222. 
Suanez, S., Blaise, E., Cancouët, R., \& Floc'h, F. (2016). Empirical parameterization of wave runup and dune erosion during storm conditions on a natural macrotidal beach. Journal of Coastal Research, (75), 932-936.

Taniguchi, M. (1993). Evaluation of vertical groundwater fluxes and thermal properties of aquifers based on transient temperature-depth profiles. Water Resources Research, 29(7), 2021-2026. https://doi.org/10.1029/93WR00541

Taylor, C. A., \& Stefan, H. G. (2009). Shallow groundwater temperature response to climate change and urbanization. Journal of Hydrology, 375(3-4), 601-612. https://doi.org/10.1016/j.jhydrol.2009.07.009

Werner, A. D., Bakker, M., Post, V. E. A., Vandenbohede, A., Lu, C., Ataie-Ashtiani, B., et al. (2013). Seawater intrusion processes, investigation and management: Recent advances and future challenges. Advances in Water Resources, 51, 3-26. https://doi.org/10.1016/j.advwatres.2012.03.004

Winner, M. D. J., \& Coble, R. (1996). Hydrogeologic framework of the North Carolina Coastal Plain.

Xin, P., Robinson, C., Li, L., Barry, D. A., \& Bakhtyar, R. (2010). Effects of wave forcing on a subterranean estuary. Water Resources Research, 46(12). https://doi.org/10.1029/2010WR009632

Xin, P., Wang, S. S. J., Robinson, C., Li, L., Wang, Y.G., \& Barry, D. A. (2014). Memory of past random wave conditions in submarine groundwater discharge. Geophysical Research Letters, 41(7), 2401-2410. https://doi.org/10.1002/2014GL059617

Zipperle, A., \& Reise, K. (2005). Freshwater springs on intertidal sand flats cause a switch in dominance among polychaete worms. Journal of Sea Research, 54(2), 143-150. https://doi.org/10.1016/j.seares.2005.01.003 


\title{
Chapter 3: \\ Groundwater head fluctuations in an intermediate depth coastal surface aquifer
}

\begin{abstract}
Three years of groundwater head observations in a roughly 20 -m deep barrier island surface aquifer are used to investigate the inland propagation of fluctuations driven by ocean water-level changes owing to diurnal and semi-diurnal tides and storms (surge and wave-driven setup). As tidal and storm-driven groundwater fluctuations propagate inland, their amplitudes decrease exponentially and their phase lags increase, consistent with small amplitude, linear shallow aquifer theory. However, similar to prior studies and inconsistent with linear theory, the inland decrease in tidal amplitude is more rapid than the change in phase. Here, the differences between tidal- and storm-induced groundwater head fluctuations are explained using theories for intermediate depth aquifers. Numerical model simulations neglecting capillary effects, hysteresis, and vertical layering (which can cause discrepancies between amplitude attenuation and phase lag evolution) are similar to the observations, and support the importance of aquifer depth. Diffusivities estimated from tidal amplitude attenuation and phase lag evolution using intermediate depth solutions are consistent with the aquifer properties, suggesting waves driven by ocean water-level fluctuations can provide large-scale information about coastal surface aquifers using the appropriate theories.
\end{abstract}




\subsection{Introduction}

Fluctuations in ocean water levels owing to tides and storms cause fluctuations in the groundwater head at the surface aquifer-ocean interface, which generate waves that propagate inland (Anderson \& Lauer, 2008; Cartwright et al., 2004; Cartwright \& Gibbes, 2011; Erskine, 1991; Ferris, 1951; Jacob, 1950; Nielsen, 1990; Raubenheimer et al., 1999; Rotzoll \& El-Kadi, 2008; Trglavcnik et al., 2018). The hydraulic gradients resulting from the groundwater waves influence mixing between ocean water and freshwater within the aquifer, affect the fate and transport of contaminants, and modulate the rate of groundwater discharge to the ocean (Boufadel et al., 2007; Moore, 2010; Robinson et al., 2006; Robinson et al., 2014), and also may affect sediment transport and evolution of the beach profile (Bakhtyar et al., 2013; Chardón-Maldonado et al., 2016; Sous et al., 2013; Turner \& Masselink 1998; Xin et al 2010).

As groundwater head waves propagate inland their amplitudes decrease (attenuate) and their arrival times increase (a phase lag equal to the distance traveled divided by the wave speed normalized by the wave period) relative to the ocean fluctuations. The propagation of groundwater head fluctuations (including amplitude attenuation and speed or phase lag) depends on the period of the water-level oscillation, aquifer properties (e.g., hydraulic conductivity $(K)$, specific yield $\left(S_{y}\right)$, aquifer depth $\left.(z)\right)$, and aquifer morphology (e.g., heterogeneity, layering). Aquifer sediments act as a low-pass filter, and high-frequency oceanic fluctuations (individual wind-waves) are attenuated within a few meters inland from the beach face. Longer period (multi-day) changes in the ocean water level owing to storms (surge and wave-driven setup, Longuet-Higgins \& Stewart, 1964) penetrate farther into the aquifer than those driven by lunar or solar tides. Groundwater head fluctuations in aquifers with larger hydraulic diffusivities (a function of $K, z, S$ ) propagate 
father inland with less amplitude damping and phase shift than those in aquifers with smaller hydraulic diffusivities.

Analytical solutions describe the propagation of tidal (the Jacob-Ferris model, Ferris, 1951; Jacob, 1950) and storm-driven (Cartwright \& Gibbes, 2011; Li et al., 2004; Rotzoll \& El-Kadi, 2008) groundwater waves through homogeneous, isotropic, shallow coastal surface aquifers with vertical ocean boundaries. Analytical solutions also have been developed to account for the effects of capillarity (Barry et al., 1996; Kong et al., 2015; Li et al., 2000), hysteresis (Cartwright et al., 2005; Nielsen \& Perrochet, 2000a,b), beach slope (Nielsen, 1990; Teo et al., 2003), and nonshallow (relative to a wavelength) aquifer depths (Nielsen et al., 1997). The theories can describe observed groundwater fluctuations, but discrepancies between the observations and analytical theories may occur owing to irregular aquifer depths (Raubenheimer et al., 1999), and connected, leaky confined and unconfined aquifer systems (Jiao \& Tang, 1999; Trglavcnik et al., 2018). In addition, when assuming linear, shallow aquifer propagation, amplitude decay rates estimated from observations can be 2 or 3 times larger than expected in comparison with phase lag rates (Erskine, 1991; Fakir and Razack, 2003; Nielsen, 1990; Rotzoll \& El-Kadi, 2008; Smith \& Hick, 2001; Trefry \& Bekele, 2004). Thus, using linear shallow aquifer theory with observed groundwater-fluctuation amplitude attenuation or phase evolution can lead to roughly a factor of 2 errors in estimation of large-scale aquifer parameters.

Here, three years of observations (Section 3.2) of ocean water levels and groundwater properties measured in the unconfined surface aquifer across a barrier island near Duck, NC are used to evaluate linear and higher-order intermediate-depth theories (Section 3.3) for groundwater head response to storms and tides. Similar to prior results, tidal cross-island amplitude attenuation 
rates are nearly twice those of phase lag rates (Section 3.4). Comparisons of the observations with analytical theories suggest that (nonlinear) intermediate-depth aquifer solutions are required to represent tidal fluctuations in this approximately 20-m-deep aquifer, whereas linear shallow aquifer theory describes the longer period (and wavelength) storm fluctuations. Numerical model simulations (MODFLOW-NWT) (Section 3.5) are consistent with the observed tidal propagation, supporting the theoretical assumptions. Using analytical theories and ocean-driven groundwater fluctuations to characterize large-scale hydrogeological properties of the aquifer are discussed, as are the effects of seasonal and storm-driven changes of inland heads and saline plumes (Section 3.6).

\subsection{Field Study}

\subsubsection{Site Description}

The North Carolina Outer Banks is a 320-km long chain of barrier islands extending south from the Virginia-North Carolina state line to Bogue Inlet, and is part of the North Carolina Coastal Plain aquifer system. The shallow geology is a 50-70 m thick Quaternary sequence that fills the Albemarle Embayment (Lautier 2009; Winner \& Coble 1996). The surficial aquifer typically is comprised of $>70 \%$ sand (Winner \& Coble 1996). A network of paleo-channels containing muddy estuarine sediment, sand, and fluvial gravel that were backfilled with younger Pleistocene sediments also weaves through the Quaternary sequence (Lazarus \& Murray 2011; Riggs et al. 1995). The surficial aquifer is underlain by a series of discontinuous clay and silt beds that comprise the Yorktown confining unit (Mallinson et al. 2010; Winner \& Coble 1996).

In September 2014, 12 groundwater wells were installed at 4 locations along a transect on the ocean-side of the barrier island, extending from behind the dune to $160 \mathrm{~m}$ inland, at the U.S. 
Army Corps of Engineers Coastal Hydraulics Laboratory Field Research Facility (FRF, http://www.frf.usace.army.mil) in Duck, NC (Figure 1, Housego et al. 2021). The property is bordered on the west by Currituck Sound and on the east by the Atlantic Ocean. On the ocean-side of the island, the beach (slope $\sim 0.1$ ) is backed by $\sim 7$-m-high vegetated dunes. Sediment samples collected during construction of the facility (Meisburger et al., 1989) and during installation of the groundwater wells suggest that the surficial aquifer is composed of medium quartz sand (mean diameter $\sim 0.25 \mathrm{~mm}$ ) and shell hash. Prior studies suggest the uppermost confining layer is roughly 15 to 30 m below NAVD88 (approximately mean sea level) (Manahan et al., 1998, Meisburger et al., 1989). However, a confining unit was not encountered during drilling, with boreholes extending from 15 (under the dune) to $26 \mathrm{~m}$ (near the sound) below NAVD88. Estimates of the hydraulic conductivity $K$ at this site range from about 15 to $90 \mathrm{~m} / \mathrm{d}$ (Manahan et al, 1998; Turner and Masselink, 1998). Additionally, although paleochannels are present throughout the Outer Banks, a prior side-scan sonar survey of the Duck study site did not identify any distinct channels or gravel outcrops (Browder \& McNinch, 2006). Based on these observations, the aquifer is assumed approximately uniform across the island at the FRF. 

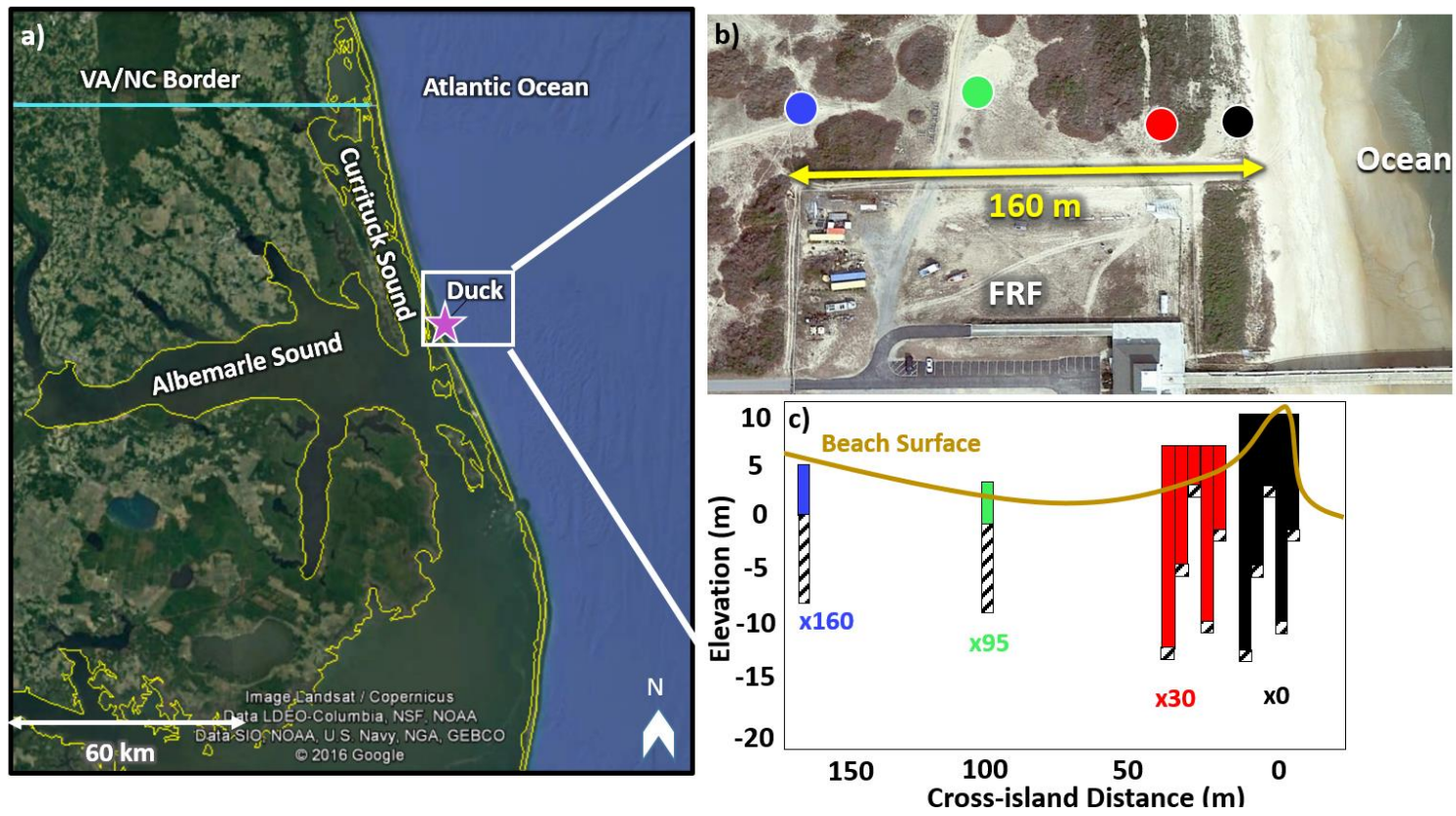

Figure 3.1: a) Google Earth image of the North Carolina Outer Banks. The border of the land is outlined in yellow. The Duck, NC U.S. Army Corps of Engineers Field Research Facility (FRF) is indicated by the purple star and is located on a barrier island between Currituck Sound and the Atlantic Ocean. b) Aerial view of the 4 groundwater well locations (colored circles). c) Elevation of the beach surface (tan curve) and groundwater wells (colored rectangles) versus cross-island distance. Wells in clusters are separated in the alongshore (in-out of the page). The crosshatched region on each well is the screened section. The number below each well location is the distance (m) from the dune crest (black circle).

\subsubsection{Observations}

The cross-shore positions ( $x$, positive toward the sound) of the well locations are defined relative to the dune crest. Each well is composed of 0.05 m-diameter PVC pipe with No.10 perforated screen at the bottom surrounded by gravel pack topped with a bentonite seal. At the two locations nearest the ocean (Figure 3.1b, red and black circles), well clusters (Figure 3.1c) were installed to measure the vertical variation in the groundwater structure (Church \& Granato 1996; Elci et al., 2001; Levanon et al., 2013). Wells in the clusters had 0.6-m-long screens and were separated $3 \mathrm{~m}$ in the alongshore. Shallow and deep wells were staggered to minimize interference between wells. The clusters consisted of 5 wells installed to depths ranging from -0.5 to $-15.4 \mathrm{~m}$ 
(NAVD88). Conductivity-temperature-depth (CTD) sensors at about mid-screen-elevation in each well were sampled at 10 min intervals. Water density is calculated (Fofonoff \& Millard, 1983) from the measured salinity, temperature, and pressure. The sensors were vented to the atmosphere so that pressure measurements are not influenced by fluctuations in barometric pressure. Sensor elevations were estimated using differential GPS measurements of the well cap, and simultaneous water-level measurements (from a standard meter) and pressure and water density measurements from the in situ sensors. Annual re-estimates show less than $0.02 \mathrm{~m}$ drift. Freshwater equivalent groundwater heads $h_{f}$ are estimated from the pressure measurements as,

$$
h_{f}=\frac{p}{\rho_{f} g}+z_{s}
$$

where $p(\mathrm{~Pa})$ is the measured pressure, $\rho_{f}\left(\mathrm{~kg} / \mathrm{m}^{3}\right)$ is the density of freshwater, $g\left(\mathrm{~m} / \mathrm{s}^{2}\right)$ is the gravitational constant, and $z_{s}(\mathrm{~m})$ is the elevation of the sensor (relative to NAVD88).

The ocean beach is surveyed monthly, and has an intertidal slope $(\beta)$ of about 0.1 . Ocean water levels measured every 6 min with a NOAA tide gauge (ID 8651371) in about $8 \mathrm{~m}$ depth at the end of the FRF pier indicate the tides are primarily semi-diurnal with range $\sim 1 \mathrm{~m}$ (Figure 3.2), and that storm surge is up to about $1 \mathrm{~m}$ (not shown). Differences between spring and neap tidal ranges are less than $0.2 \mathrm{~m}$ (spring-neap groundwater fluctuations are much smaller than diurnal, semi-diurnal, and storm-driven fluctuations). Significant wave heights $\left(H_{s}, 4\right.$ times the standard deviation of sea-surface elevation fluctuations in the frequency range from 0.05 to $0.30 \mathrm{~Hz}$ ) recorded every $30 \mathrm{~min}$ in 26-m water depth (NDBC station 44100) ranged from near 0 to $6 \mathrm{~m}$ (Figure 3.2 is during a calm summer period), with an average of about $1 \mathrm{~m}$. Wave energy in the north Atlantic Ocean varies seasonally, and often is largest during the fall and winter. Breaking 
wave-driven setup of the shoreline water levels is estimated to be about 0.2 times the offshore significant wave height (Guza \& Thornton, 1981; Nielsen, 1988; Raubenheimer et al., 2001), roughly consistent with observations from a LIDAR on the dune about $300 \mathrm{~m}$ north of the wells. Ocean salinity ranged from 24 to 34 PSU.

Storms are defined as events with combined 36-hr averaged (de-tided) surge and setup exceeding $0.65 \mathrm{~m}$. There were 26 storm events during the 3 -year data record, including 4 hurricanes that passed offshore of Duck, NC (Hurricane Joaquin Oct. 2015, Hurricane Matthew Oct. 2016, Hurricane Irma Sep. 2017 and Hurricane Maria Sep. 2017) with minimal rainfall $(<0.05 \mathrm{~m})$.

During calm conditions $\left(H_{s}<\sim 2 \mathrm{~m}\right)$, tides are the dominant driver of fluctuations in the groundwater, with semi-diurnal amplitudes of approximately $0.2 \mathrm{~m}$ under the dune crest that attenuate inland (Figure 3.2b). During storms, the combined effects of storm surge, setup, and wave infiltration generate groundwater head fluctuations that are approximately 1 order of magnitude larger than the tidally driven groundwater head fluctuations (Figure 3.3). The range of storm-driven head increases observed at the dune-crest well (x0) is $0.40-1.50 \mathrm{~m}$ for the 26 storm events, with the largest increase measured when Hurricane Joaquin passed offshore in Oct 2015. Storm-driven increases in the head levels also attenuate with inland distance, and $160 \mathrm{~m}$ inland of the dune (at sensor $\mathrm{x} 160$ ) the maximum increase in head is $0.9 \mathrm{~m}$. Similar to the tidal fluctuations, there are time delays (phase lags) in the occurrences of maximum water levels at each well location as the groundwater head fluctuation propagates inland (Figure 3.3b). The inland propagation speed of the storm driven groundwater levels ranged from $\approx 60-150 \mathrm{~m} /$ day depending on the duration (i.e., the period or frequency) of the elevated ocean water levels. 

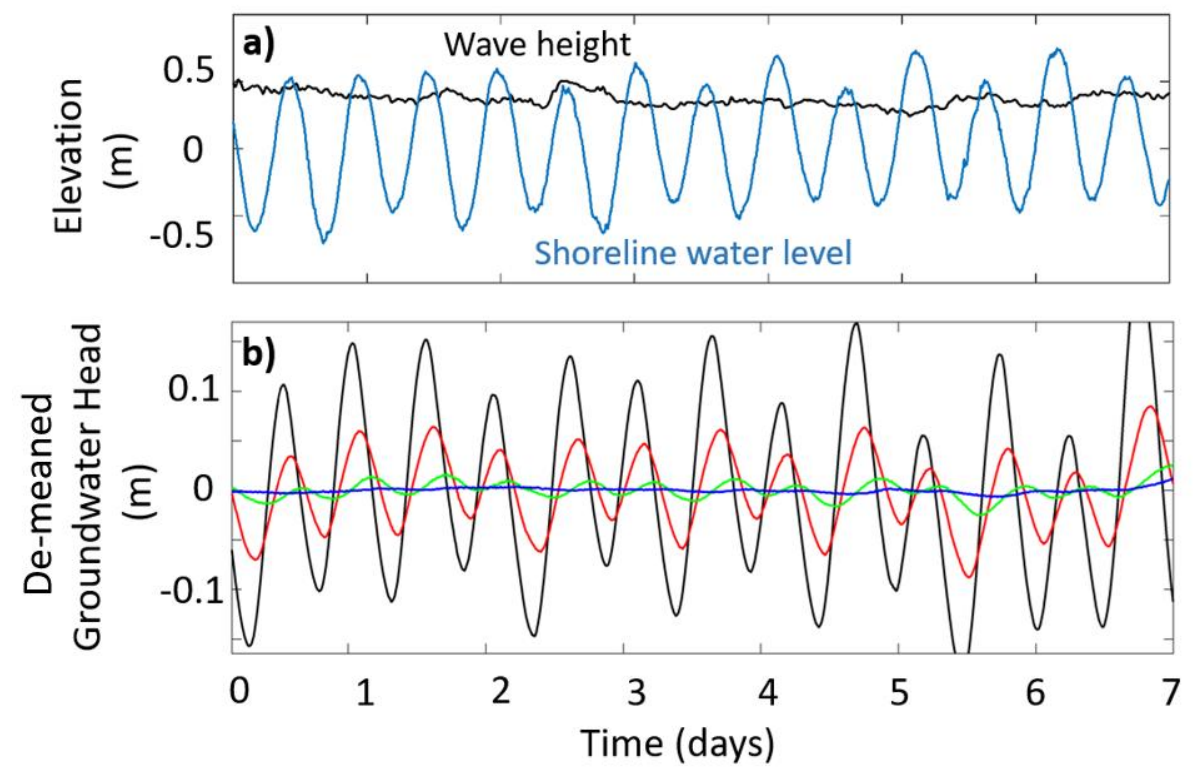

Figure 3.2: a) Offshore (26-m water depth) significant wave height (black) and shoreline water level (blue, including tides, storm surge, and setup) and b) demeaned freshwater equivalent head $(\mathrm{x}=0,30,95$, and $160 \mathrm{~m}$ are black, red, green, and blue curves, respectively) versus time during calm conditions (July 2016).
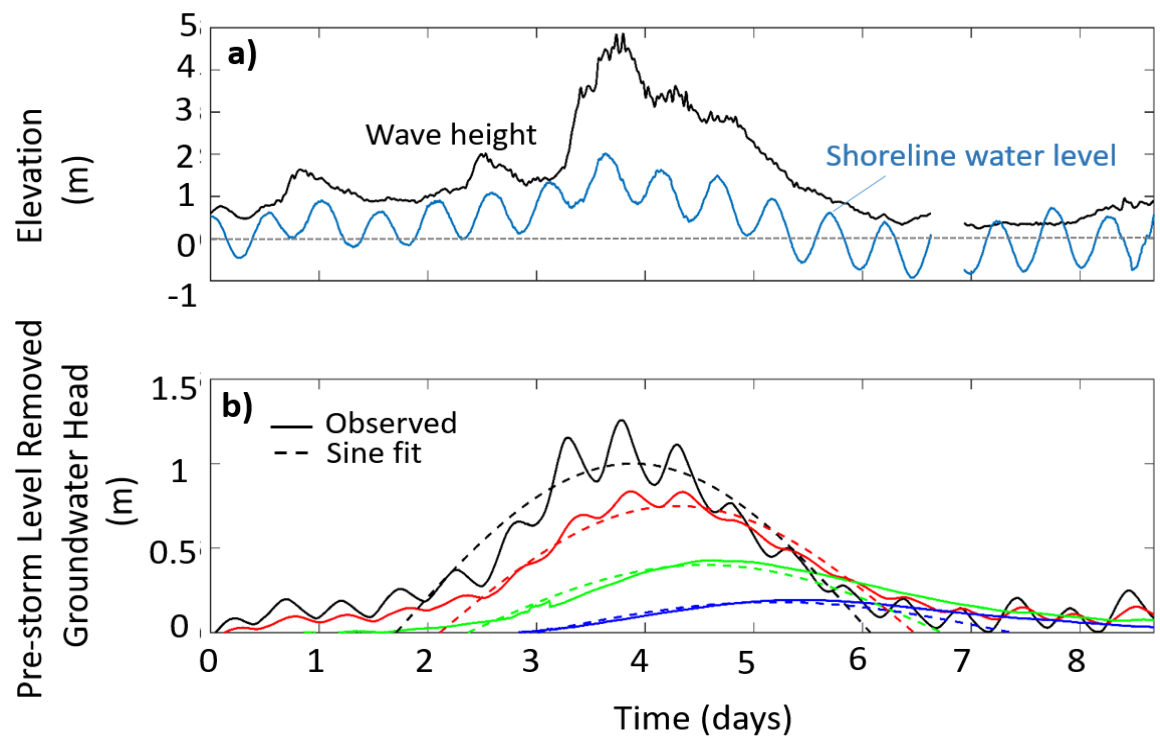

Figure 3.3: a) Offshore significant wave height (black) and shoreline water level (blue) and b) observed (solid curves) and sine curve fits $\left(\omega=0.72 \mathrm{~d}^{-1}\right.$, dashed curves) to freshwater equivalent groundwater head elevations above the pre-storm levels versus time for a single nor'easter (Sept 2014). Colors for $\mathrm{x}=0,30,95,160 \mathrm{~m}$ are black, red, green, and blue, respectively. 


\subsection{Analytical Theories}

The analytical theories considered here assume a homogeneous, isotropic surface aquifer with uniform saturated hydraulic conductivity $K(\mathrm{~m} / \mathrm{d})$, specific yield $S_{y}$ (dimensionless), and constant depth $z(\mathrm{~m})$ (bounded below by a horizontal impermeable layer). Capillary effects are neglected. Amplitudes $A(\mathrm{~m})$ of groundwater head fluctuations are assumed small relative to the aquifer depth $\left(A_{\text {ocean }} / z \approx 1 / 20<<1\right)$. The intertidal region of the relatively steep beach is only about $10 \mathrm{~m}$ wide, and the aquifer is assumed to be connected to the ocean by a vertical beach face.

\subsubsection{Linear Theory}

Assuming further that the aquifer is shallow relative to the wavelength of the groundwater head fluctuation $\left((k z)^{2} \ll 1\right.$, where $k\left(\mathrm{~m}^{-1}\right)$ is the wavenumber), and thus that velocities are horizontal and uniform with depth (and that pressures are hydrostatic as in the Dupuit-Forchheimer assumption), Darcy's Law and continuity combine to give the diffusion equation (Ferris, 1951; Jacob, 1950; Nielsen 1990):

$$
\frac{\partial h}{\partial t}=\frac{K z}{S_{y}} \frac{\partial^{2} h}{\partial x^{2}}
$$

where $h(\mathrm{~m})$ is the space and time dependent aquifer head, $t(\mathrm{~d})$ is time, and $x(\mathrm{~m})$ is the cross-shore coordinate positive inland from the ocean boundary. In this simplified case, the head fluctuation is an inland propagating wave with period $\tau(\mathrm{d})$ and exponentially decaying amplitude (Eq. 3):

$$
h(x, t)=A_{0} \cos \left(\frac{2 \pi}{\tau}-k_{i} x\right) e^{-k_{r} x}
$$


in which $A_{0}$ is the amplitude at the ocean boundary, $k_{r}$ and $k_{i}$ are the real and imaginary parts of the complex wavenumber $k$ given by:

$$
k=\sqrt{\frac{i 2 \pi S_{y}}{\tau K z}}
$$

where $\mathrm{i}$ is $\sqrt{-1}$. Although according to linear theory $k_{i}=k_{r}$, many studies have found discrepancies between these wave number estimates. If the assumption of small amplitude is relaxed, the solution for $h(x, t)$ includes an overheight and harmonics of the primary fluctuation (both of order $A^{2} / 4 z \approx$ $0.01 \mathrm{~m}$ for this site). Relaxing the vertical beach assumption results in an overheight and harmonics of the order $k A^{2} \cot \beta(\approx 0.1 \mathrm{~m})$ (Nielsen, 1990; Raubenheimer et al., 1999). However, tidal harmonics are several orders of magnitude smaller than diurnal and semi-diurnal fluctuations (Figure 3.4a), supporting the assumptions of small amplitude and a vertical beach. The small tidal harmonics are not examined further.

\subsubsection{Higher-Order Intermediate Depth Theories}

Deviations from the assumptions of the linear theory, including an inhomogeneous (Trglavcnik et al., 2018) or deep (Nielsen et al., 1997) aquifer, spatially variable aquifer depth (Raubenheimer et al., 1999), capillary effects (Barry et al., 1996; Kong et al., 2013; Li et al., 2000; Shoushtari et al., 2016), large amplitude fluctuations, hysteresis (Cartwright et al., 2005; Nielsen \& Perrochet, 2000ab; Nielsen \& Turner, 2000), and a sloping beach (Nielsen, 1990; Raubenheimer et al., 1999) can result in generation of tidal harmonics in groundwater fluctuations or differences between the rate of amplitude attenuation and phase evolution. Although many of the linear theory assumptions approximately may be valid for the range of hydraulic conductivity $(15<K<90 \mathrm{~m} / \mathrm{d})$ previously estimated at this site, the aquifer depth $(15<z<30 \mathrm{~m})$ violates the shallow aquifer 
(relative to a wavelength) assumption at tidal frequencies $\left((k z)^{2}=S_{y} \omega z / K>0.2\right.$, where $\omega=2 \pi / \tau$ is the radian frequency of the fluctuations with period $\tau$ ).

As the aquifer depth increases, horizontal velocities become non-uniform with depth and vertical velocities can be significant (Dagan, 1967; Parlange et al., 1984; Fenton, 1990), in contrast with the hydrostatic Dupuit-Forchheimer shallow aquifer assumption. For the small fluctuation amplitudes considered here, the equations for groundwater head fluctuations in homogeneous, intermediate depth aquifers, without capillary effects or hysteresis, are to $2^{\text {nd }}$ and infinite order, respectively, given by (Nielsen et al., 1997):

$$
\frac{\partial h}{\partial t}=\frac{K z}{S_{y}}\left(\frac{\partial^{2} h}{\partial x^{2}}+\frac{z^{2}}{3} \frac{\partial^{4} h}{\partial x^{4}}\right)
$$

and

$$
\frac{\partial h}{\partial t}=\frac{K z}{S_{y}}\left(\tan \left(z \frac{\partial}{\partial x}\right) \frac{\partial h}{\partial x}\right)
$$

where $h$ the surface displacement (with $h<<z$ ). As in the linear theory result, the solution for the head fluctuation is an inland propagating wave with exponentially decaying amplitude (Eq. 3). However, the amplitude decay rate and phase evolution, given by the real and imaginary parts of the wavenumber, respectively, no longer are equal $\left(k_{r}>k_{i}\right)$, with the $2^{\text {nd }}$-order and infinite-order dispersion relationships given by:

$$
k z=\sqrt{\frac{3}{2}} \sqrt{-1+\sqrt{1+\frac{4 i S_{y} \omega z}{3 K}}}
$$

and

$$
k z \tan k z=\frac{i S_{y} \omega z}{K}
$$


The $2^{\text {nd }}$-order approximation is valid for $S_{y} \omega z / K<1.0$. As $S_{y} \omega z / K \rightarrow \infty$, the infinite order theory predicts that there will be zero phase lag and the amplitude attenuation rate will asymptote to $\pi / 2 z$. Intermediate depth theory also predicts that oscillations near the bottom of the aquifer lead the oscillations near the surface of the aquifer, with the vertical variation of the phase $\phi$ with depth given by (Neilsen et al., 1997):

$$
\phi(x, d)=\phi(x, 0)+\operatorname{Arg}\left\{i \sin \left(k_{i} d\right)+\cos \left(k_{r} d\right)\right\}
$$

where $d$ is distance above the bottom of the aquifer. Additionally, oscillations near the bottom of the aquifer are predicted to have slightly larger amplitudes than those at the surface.

\subsubsection{Data Processing for Theory Evaluation}

Diurnal and semi-diurnal tidal amplitude attenuation and phase lag relative to observations at the $\mathrm{x} 0$ well are calculated from cross-spectral analysis (Figure 3.4). The 3-yr data record is divided into 15 subsamples, each with 10240 data points ( 70 days each). Each subsample is then broken into ensemble sections of 2048 data points ( 14 days) with 75\% overlap. Each ensemble section is de-meaned and quadratically detrended to remove low-frequency oscillations, such as seasonal trends, and tapered with a Hamming window to remove ringing artifacts. Five frequency bands are merged to increase the degrees of freedom. The resulting spectra have 50 degrees of freedom and a $0.0146 \mathrm{hr}^{-1}$ bandwidth $(\Delta f)$. Phase difference and spectral density $\left(S_{d}\right)$ are extracted from the band containing the frequency of each tidal constituent (vertical orange and magenta lines, Figure 3.4). Amplitude is determined from the spectral density at each location as $A=\sqrt{2 S_{d} \Delta f}$. 
Coherence between the $\mathrm{x} 0$ well and all three inland locations is significant at the $95 \%$ confidence level for the semi-diurnal and diurnal tides for 5 of the 15 subsamples. Low coherence could be owing to attenuation of the tidal fluctuations, which subsequently may be too weak to resolve at inland locations under some conditions (such as high inland groundwater heads, see Section 3.6.2). Low coherence also could be owing to storm events that are not well represented by sine waves and cause "noise" at a wide range of frequencies, or brief, heavy impulse-like precipitation events (often not associated with storms) that could put apparent energy into all frequencies and could decrease coherence levels. Leakage into higher frequencies from the springneap cycle, which is not well resolved in the 14-day subsamples, and from other low-frequency fluctuations that could not be removed completely by detrending, also may obscure the tidal signals. Thus, only the five 70-day-long subsamples with significant coherence levels at the diurnal and semi-diurnal tidal frequencies at all three inland locations are considered. 

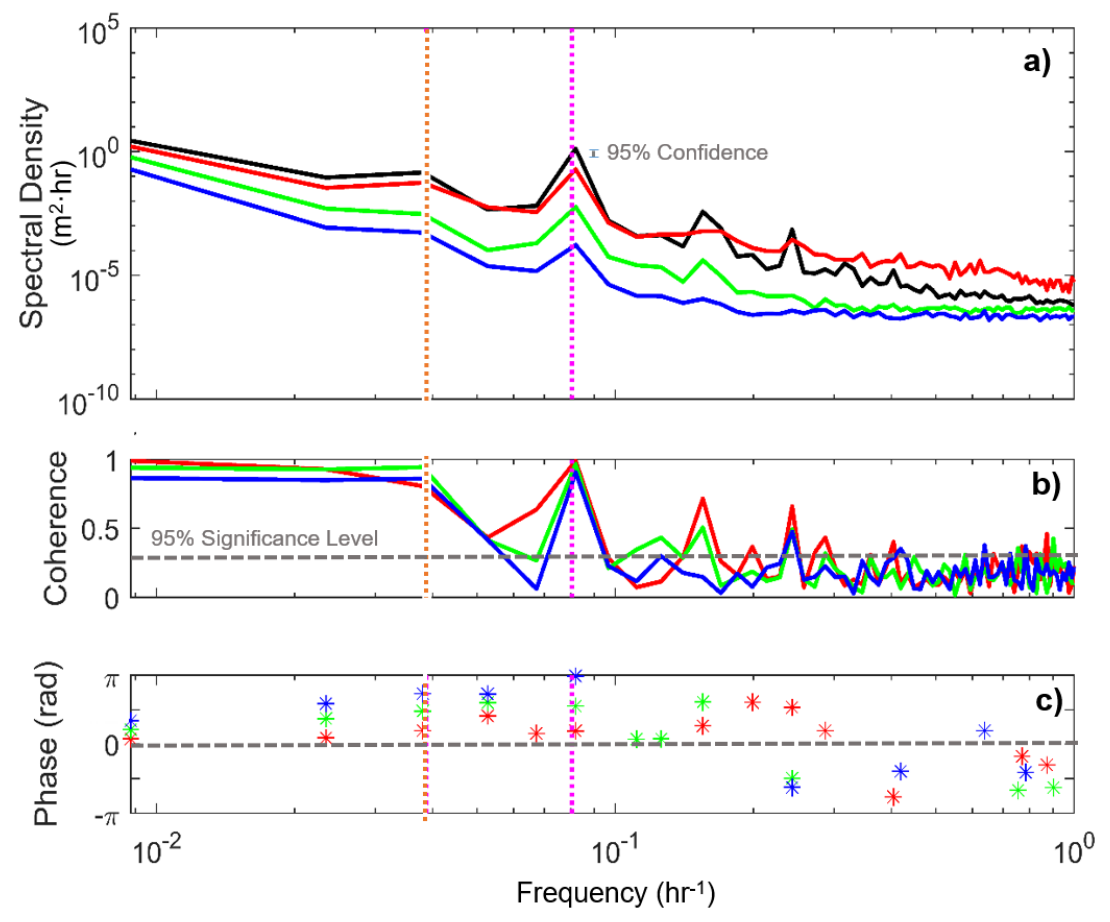

Figure 3.4: a) Spectral energy density $\left(\mathrm{m}^{2} \mathrm{hr}\right)$, b) coherence with the signal at $\mathrm{x} 0$, and c) phase (radians) shift relative to $\mathrm{x} 0$ versus frequency for 70 days of data (50 degrees of freedom). Vertical lines identify the diurnal (orange) and semi-diurnal (magenta) tidal frequencies, and the horizontal dashed line in (b) is the $95 \%$ significance level for zero coherence. Colors for wells located at $\mathrm{x}=0$, $30,95,160 \mathrm{~m}$ are black, red, green, and blue, respectively and correspond to well locations in Figure 1.

Storm amplitude attenuation and phase lag are determined by fitting a sine curve to the 36-hr average groundwater head after removing the pre-storm head level at each well (Figure 3.3b). The amplitude $A$ of the fit is specified to be the maximum observed 36-hr average head level at each location, the frequency (period) is determined by the best fit at the $\mathrm{x} 0$ well, and the phase lag $\Delta(\phi)$ is estimated as the time difference of the maximum head at each location from that at the $\mathrm{x} 0$ well normalized by the period. Fit agreements are better for storms where the rise and subsequent fall of the shoreline water level is approximately symmetric in time. Additionally, the same frequency is used at all well locations, so the fit agreement is better at $\mathrm{x} 0$ and $\mathrm{x} 30$ because the 
duration of the groundwater head fluctuation increases with inland distance owing to dispersion. Despite these limitations, the sine curve fits have correlations of $\mathrm{R}^{2}>0.7$ at all well locations for all storms. Storms associated with heavy precipitation are not included in the analysis because the precipitation drives a simultaneous increase in head at all well locations.

The real and imaginary wave numbers are computed for the diurnal, semi-diurnal, and storm fluctuations from the best-fit cross-shore trends of amplitude attenuation and phase lag (from Eq. (3)) as:

$$
\begin{gathered}
|\ln (\alpha)|=k_{r} x \\
|\Delta \phi|=k_{i} x
\end{gathered}
$$

where $x(\mathrm{~m})$ is the cross-shore distance from the $\mathrm{x} 0$ well, $\alpha$ (non-dimensional) is the amplitude relative to the amplitude at the $\mathrm{x} 0$ well $\left(A / A_{0}\right)$, and $\Delta(\phi)(\mathrm{rad})$ is the phase difference relative to the signal at the $\mathrm{x} 0$ well.

\subsection{Observational Estimates of Cross-shore Propagation and Vertical Structure of Groundwater Head Fluctuations}

The logarithms of the tidal and storm amplitude attenuation and the phase lags (Eq. 10)

decrease linearly inland (Figure $3.5, \mathrm{R}^{2}>0.9$, Table 1 (tides only)) as expected from theory, and consistent with the assumptions of a homogeneous and isotropic surface aquifer (Nielsen 1990). The rates (slopes in Table 1, and wavenumbers in Table 2 ) of amplitude attenuation $\left(k_{r}\right)$ and phase lag evolution $\left(k_{i}\right)$ increase with the frequency of the fluctuation, consistent with the dispersion 
relation for groundwater waves (Eqs. 4, 7, and 8). Thus, storm-driven groundwater head fluctuations propagate more rapidly and attenuate less than the higher-frequency tidal oscillations.
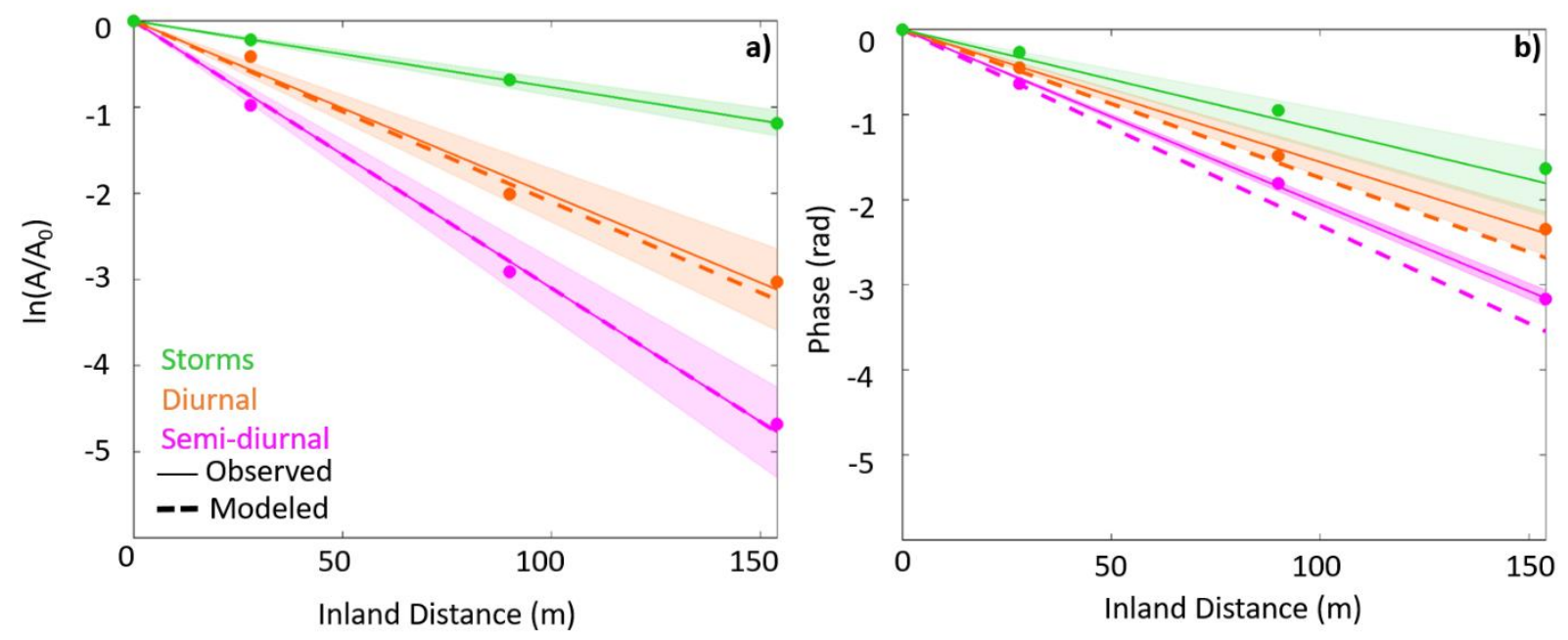

Figure 3.5: a) Amplitude attenuation and b) phase lag versus inland distance of storm- (green, $\mathrm{n}=26$ ), diurnal (orange, $\mathrm{n}=5$ ), and semi-diurnal (pink, $\mathrm{n}=5$ ) driven groundwater fluctuations. Filled symbols are the mean observed values at each location, the solid lines are the average slope from the least squares linear fits to each set of observations, the shaded areas represent \pm 1 standard deviation of the least squares linear fit slopes, and the dashed lines are the model simulations for an aquifer diffusivity of $6000 \mathrm{~m}^{2} / \mathrm{d}$.

Table 1. Slopes and correlations $\boldsymbol{R}^{2}$ of least squares fits to tidal amplitude attenuation and phase lag with inland distance, and the slope factor, the ratio of the slope of the phase to the slope of the amplitude fit for that frequency for each of the five 70-day periods with high correlations.

\begin{tabular}{|c|c|c|c|c|c|c|c|c|c|}
\hline \multicolumn{4}{|c|}{ Amplitude } & \multicolumn{4}{|c|}{ Phase } & \multirow{2}{*}{\multicolumn{2}{|c|}{ Slope Factor }} \\
\hline \multicolumn{2}{|c|}{ Diurnal } & \multicolumn{2}{|c|}{ Semi-diurnal } & \multicolumn{2}{|c|}{ Diurnal } & \multicolumn{2}{|c|}{ Semi-diurnal } & & \\
\hline Slope & $R^{2}$ & Slope & $R^{2}$ & Slope & $R^{2}$ & Slope & $R^{2}$ & Diurnal & Semi-diurnal \\
\hline-0.0215 & 0.918 & -0.0306 & 0.995 & -0.0137 & 0.936 & -0.0205 & 0.999 & 0.64 & 0.67 \\
\hline-0.019 & 0.975 & -0.0295 & 0.996 & -0.0156 & 0.959 & -0.0200 & 0.998 & 0.82 & 0.68 \\
\hline-0.0198 & 0.853 & -0.0326 & 0.986 & -0.0167 & 0.988 & -0.0200 & 0.996 & 0.84 & 0.61 \\
\hline-0.0237 & 0.992 & -0.0347 & 0.994 & -0.0169 & 0.999 & -0.0211 & 0.998 & 0.71 & 0.61 \\
\hline-0.0172 & 0.973 & -0.0276 & 0.996 & -0.0149 & 0.998 & -0.0209 & 0.997 & 0.87 & 0.76 \\
\hline
\end{tabular}

For the individual storms (which have a range of estimated frequencies,

$\left.\omega=0.20-0.85 \mathrm{~d}^{-1}\right)$, the shallow aquifer parameter $(k z)^{2}$ is less than 0.15 for the estimated aquifer depth $15<z<30 \mathrm{~m}$, satisfying the shallow aquifer assumption (Figure 3.6). The storms are 
consistent with all theories within $95 \%$ confidence levels. However, the average storm $k_{i}(0.012$, Table 2$)$ is $50 \%$ larger than the average $k_{r}(0.008$, Table 2$)$, in contrast with linear shallow aquifer theory for which $k_{r}=k_{i}$, possibly owing to inaccuracies of modeling storms as sine waves. In particular, an analytical theory (Li et al. 2004) suggests that storm-driven fluctuations modeled as a Gaussian pulse propagate faster than those approximated as a sine wave, and thus have a smaller $k_{i}$ and would be more consistent with linear shallow aquifer theory. The estimated amplitudes and phase lags of storm fluctuations are approximately vertically uniform (consistent with linear shallow aquifer theory, not shown). 


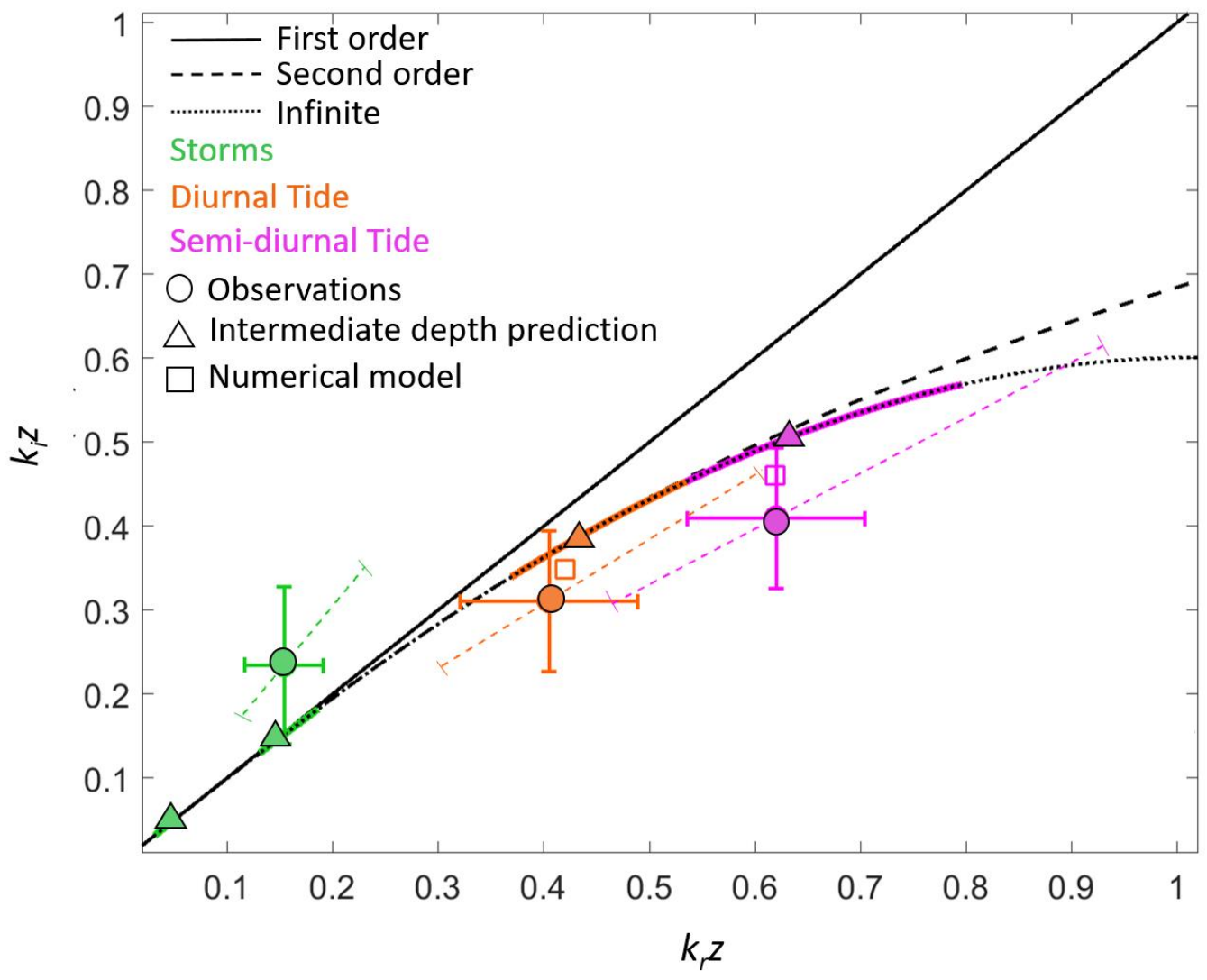

Figure 3.6: Imaginary versus real component of the wave number scaled by aquifer depth (using $z=$ $20 \mathrm{~m}$ ) estimated from observations (filled circles), simulations (open squares), and intermediate depth theory (filled triangles, Eq. 8) for the storm (green), diurnal (orange), and semi-diurnal (magenta) propagation. The curves represent the linear (solid black, Eq. 4), 2nd-order (dashed black, Eq. 7), and infinite-order (dotted black, Eq. 8) in depth, small-amplitude dispersion relations. The shaded solid colors along the intermediate depth solution show the intermediate depth theory predictions over a range of depth estimates $(\mathrm{z}=15-30 \mathrm{~m})$ for storms (green), diurnal(orange) and semi-diurnal(magenta) propagation. Solid bars on the observed estimates represent $+/-1$ standard deviation of the observational estimates (shaded areas in Figure 5), dashed bars show the range of observational estimates over a range of depth estimates $(\mathrm{z}=15-30 \mathrm{~m})$. Theoretical estimates for storms (green triangles) are given for the largest and smallest observed periods. The numerical and theoretical values assume $S_{y}=0.2$ based on site characterization and $K=60 \mathrm{~m} / \mathrm{d}$ based on a fit to the observations

For the diurnal and semi-diurnal tidal fluctuations, the wavenumbers estimated from the amplitude attenuation and phase evolution suggest the shallow aquifer assumption may be violated given the estimated aquifer depth range (Figure 3.6 and Table 2). Furthermore, consistent with the 
intermediate depth theories, the tidal fluctuations have more rapid rates for amplitude attenuation $\left(k_{r}\right)$ than the rates for phase lag evolution $\left(k_{i}\right)$. Estimates of $k_{i}$ and $k_{r}$ predicted by infinite-order dispersion (Eq. 8) for $K=60 \mathrm{~m} / \mathrm{d}$ and $\mathrm{z}=20 \mathrm{~m}$ (best fit of infinite-order theory to observations, see Section 3.5) fall within 1 standard deviation of the observed values for both storms and tides.

Table 2: Average estimated wave numbers (n=number of storm events or 70-day-long tidal records averaged).

\begin{tabular}{|c|c|c|c|c|c|}
\hline \multicolumn{3}{|c|}{$\mathbf{k}_{\mathbf{r}}$} & \multicolumn{3}{c|}{$\mathbf{k}_{\mathbf{i}}$} \\
\hline $\begin{array}{c}\text { Storms } \\
(\mathrm{n}=26)\end{array}$ & $\begin{array}{c}\text { Diurnal } \\
(\mathrm{n}=5)\end{array}$ & $\begin{array}{c}\text { Semi-diurnal } \\
(\mathrm{n}=5)\end{array}$ & $\begin{array}{c}\text { Storms } \\
(\mathrm{n}=26)\end{array}$ & $\begin{array}{c}\text { Diurnal } \\
(\mathrm{n}=5)\end{array}$ & $\begin{array}{c}\text { Semi-diurnal } \\
(\mathrm{n}=5)\end{array}$ \\
\hline 0.008 & 0.020 & 0.031 & 0.012 & 0.016 & 0.021 \\
\hline
\end{tabular}

Cross-spectral analysis for the same fifteen 70-day-long subsamples as used for the horizontal propagation analysis demonstrates that diurnal and semi-diurnal fluctuations below the surface are correlated (Figure 3.7b) with those at the surface at the two well clusters closest to the ocean (x0 and x30, the black and red wells in Figure 3.1b, c). Depth-dependent variations in tidal amplitudes cannot be resolved (smaller than the 95\% confidence limits, Figure 3.7a), which is not inconsistent with the higher-order theories. However, consistent with intermediate depth theory (Eq. 9, Nielsen et al., 1997) and with (unpublished) laboratory observations (Nielsen, pers. comm.), the semi-diurnal tidal signal at the deepest location leads the signal at shallower locations (Figure 3.8), and the vertical dependence of the phase shift does not depend on cross-shore location (compare Figure $3.8 \mathrm{a}$ for $\mathrm{x} 0$ with Figure $3.8 \mathrm{~b}$ for $\mathrm{x} 30$ ). Differences between the observed and theoretical vertical structure may arise from the sloping beach or vertical salinity structure. The vertical dependent diurnal phase shifts are about half of those for the semi-diurnal tide (Figure 3.7c), consistent with theory. However, the diurnal phase shifts do not increase monotonically with depth for all fifteen subsamples, as would be expected from theory. 

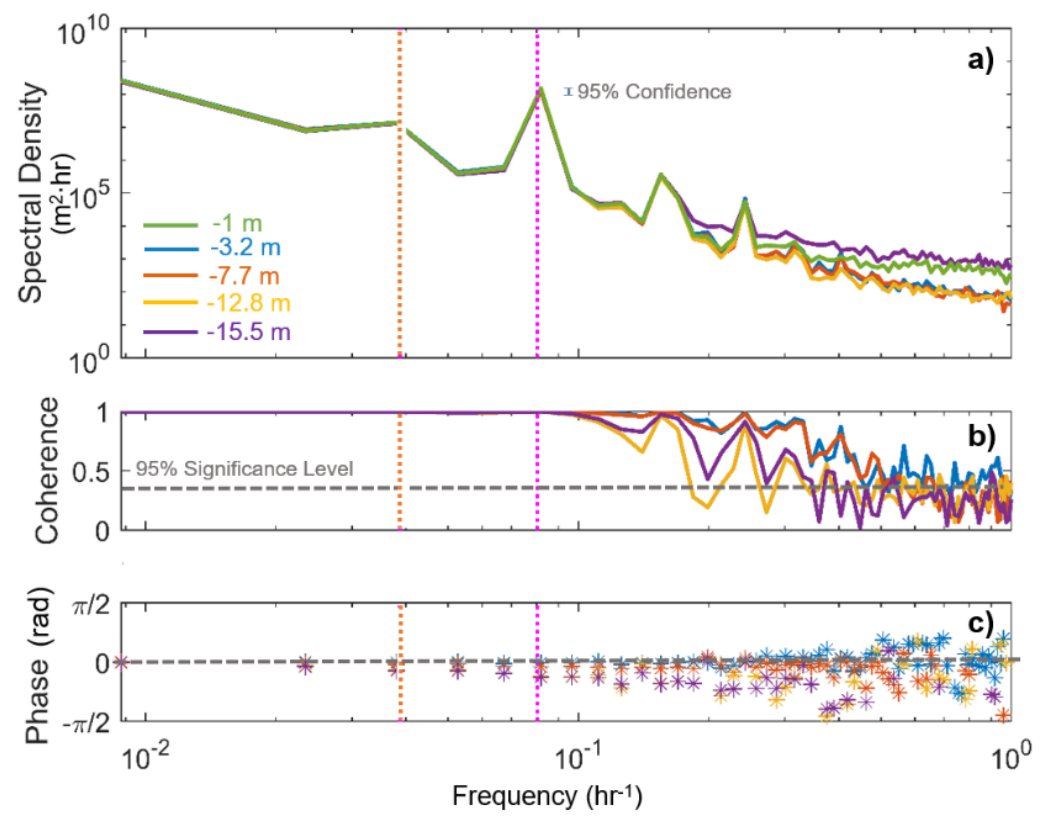

Figure 3.7: a) Spectral energy density $\left(\mathrm{m}^{2} \mathrm{hr}\right)$, b) coherence with the signal at the shallowest well $(-1 \mathrm{~m})$, and c) phase shift relative to the shallowest well versus frequency for all wells at the $\mathrm{x} 0$ site. Vertical lines identify the diurnal (orange) and semi-diurnal (magenta) tidal frequencies, and the horizontal dashed line in (b) is the $95 \%$ significance level for zero coherence. Color key for well depths is given in (a).
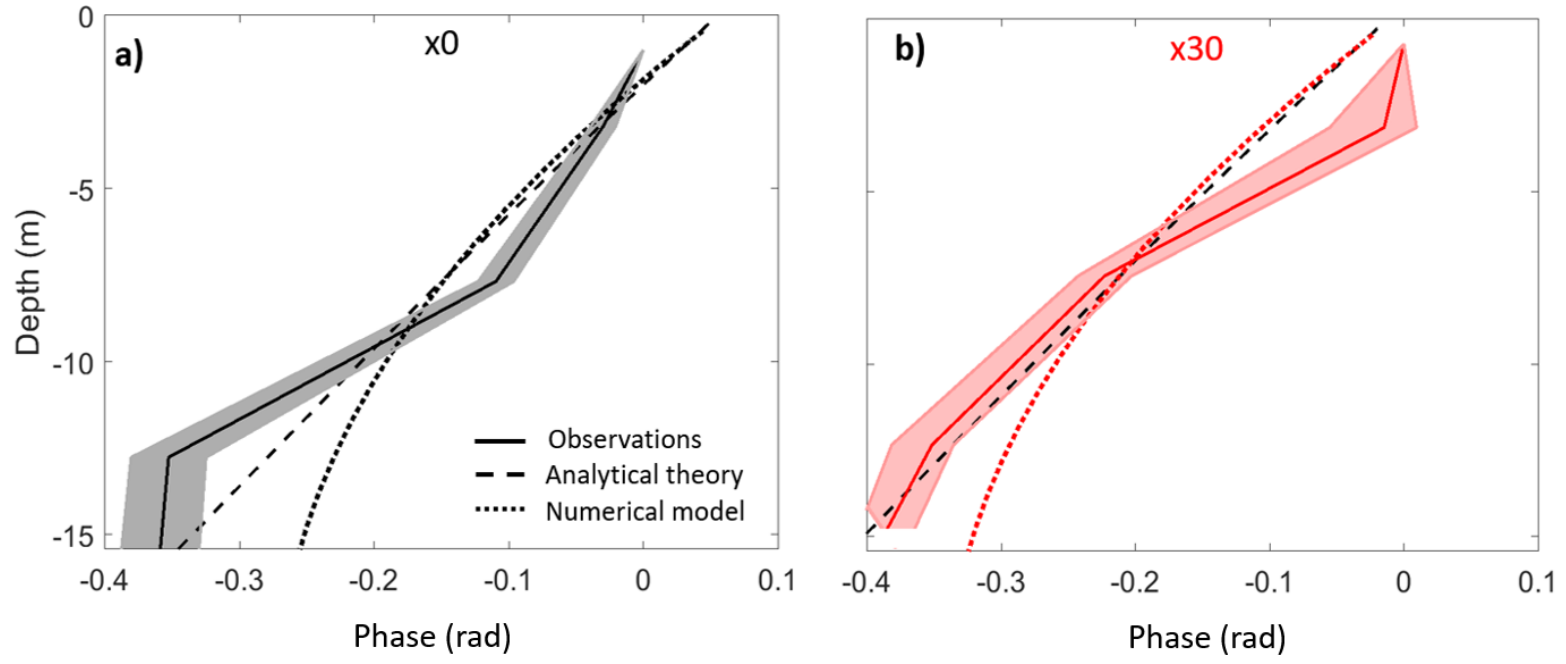

Figure 3.8: Phase relative to the shallowest well versus depth at a) $x 0$ and b) $x 30$ for semi-diurnal tidal fluctuations. Shaded regions represent the $95 \%$ confidence interval based on the range of measured estimates across all subsamples. Dotted lines are the phase differences extracted from the numerical model. Dashed black lines are the theoretical profiles (Nielsen et al., 1997). 
The intermediate aquifer estimates do not account for hysteresis, which could cause reduced amplitude attenuation and phase lag evolution with increasing period (Cartwright, 2014; Shoushtari et al., 2015; Werner \& Lockington, 2003), crudely consistent with the observations. However, analytical theories including hysteresis (or capillarity) (Shoushtari et al., 2016) predict larger ratios of real to imaginary wavenumbers than those estimated from the observations (circles in Figure 3.6), and dispersion relationships (curves in Figure 3.6) that include hysteresis and capillary effects (not shown) would result in poorer agreement with the observations for the specified hydrogeologic parameters. Shorter period tidal harmonics (M4 and M6, Figures 3.4a and 3.7a) are weak, and cannot be used to explore the asymptotic behavior of $k_{r}$ and $k_{i}$ with increasing non-dimensional aquifer depth.

\subsection{Numerical Simulations for a Homogeneous, Intermediate Depth Aquifer}

To examine further the importance of neglecting capillarity, hysteresis, and vertical layering, tidal and storm-driven groundwater fluctuations are simulated with a uniform density groundwater transport model (MODFLOW-NWT (Niswonger et al. 2011)) for a constant depth, homogeneous, isotropic surface aquifer without a capillary fringe, as assumed in the theories. MODFLOW-NWT is used because of its ability to include the nonlinearity associated with wetting and drying processes (Bedekar et al. 2012, Hunt \& Feinstein 2012), despite the model's limitation to uniform density. A uniform-density approach is consistent with the analytical theories applied in Section 3.4 and variable-density effects are not hypothesized to extend inland of the intertidal (see Section 3.6.2). 
The 2-dimensional model domain represents a vertical cross-section that extends from 200 $\mathrm{m}$ inland to $250 \mathrm{~m}$ offshore of the dune (Figure 3.9). The observed ocean beach configuration varied significantly over the 3-year field study owing to erosion and accretion. Rather than using a snapshot of a single beach state, the beach is approximated as linear with a 0.1 slope. The vertical grid resolution ranges from 0.1 to $1.0 \mathrm{~m}$ from the surface to the bottom, and the horizontal resolution ranges from 0.1 to $5.0 \mathrm{~m}$, with the highest resolution along the beach face, similar to prior studies (Heiss \& Michael 2014; Mulligan et al. 2011; Robinson et al. 2007, 2014). The hydrogeologic parameters $\left(z=20 \mathrm{~m}, S_{y}=0.2\right)$ are based on geologic characterizations of the region and the observed propagation of the tide and storm fluctuations. In particular, using the above estimated 20-m aquifer depth and specific yield, the hydraulic conductivity that yields the best match between theory and observations (smallest percent error between measurement and theory prediction) for all fluctuation periods is $K=60 \mathrm{~m} /$ day $\left(D=6000 \mathrm{~m}^{2} / \mathrm{d}\right)$, consistent with previous estimates at this site (Turner and Masselink, 1998). A model run including vertical anisotropy $\left(\mathrm{K}_{\mathrm{x}}: \mathrm{K}_{\mathrm{z}}=10: 1\right)$ yields the same propagation results for storms and tides as the isotropic runs.

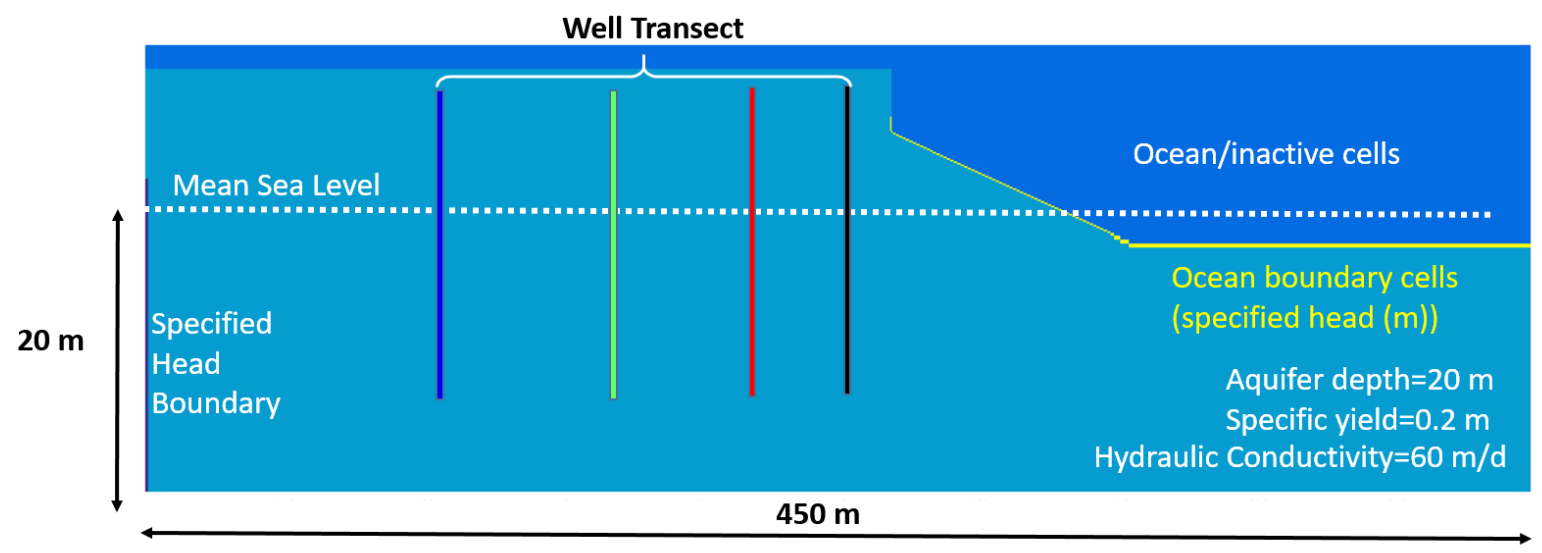

Figure 3.9: Schematic of the model domain 
No flow boundaries are applied at the bottom of the model domain and at the vertical ocean boundary. Inland of the beach the elevation of the top of the model domain is above the maximum height of the simulated water table (no exchange across the top horizontal boundary). Significant seepage face development is not expected (and was not observed) for this steep beach slope $(\beta=0.1)$, and is neglected at the model shoreline. For wetting and drying processes, the thickness factor (THICKFACT) was specified as 0.001 and a correction was applied to the groundwater head relative to the cell-bottom altitude if the cell is surrounded by dewatered cells (IBOTAV=1). Tidal fluctuations attenuate prior to reaching the inland boundary (fluctuation amplitude $<0.001 \mathrm{~m}$ ), where a Dirichlet boundary is applied using the CHD package. The landward Dirichlet boundary is set to $0.7 \mathrm{~m}$ based on extrapolating the average observed head gradient to the inland model boundary. At the ocean-side boundary, the periodic-boundary condition package (Post 2011) was modified to enable direct input of time series of shoreline water levels (instead of harmonic constituents) assuming a flat sea surface.

Numerical simulations were driven at the offshore boundary with 0.5 -m amplitude (i) semidiurnal and (ii) diurnal tides. Semi-diurnal and diurnal tidal simulations were each run for 30 days, including a 7-day spin-up period. Head data were extracted at a depth of $-5 \mathrm{~m}$ (which overlaps with the depth of well screens) every $5 \mathrm{~m}$ in the cross-shore, at and onshore of the position of the $\mathrm{x} 0$ well. Head data also were extracted every $1 \mathrm{~m}$ in the vertical extending from $z=0 \mathrm{~m}$ to $z=-15 \mathrm{~m}$ NAVD88 (max. well depth) at the position of the $\mathrm{x} 0$ and $\mathrm{x} 30$ wells. Amplitudes and phases were estimated from quadratically detrended head data using a least squares fit to sine waves. The head fluctuation is too small to be resolved at locations more than $90 \mathrm{~m}$ inland of the $\mathrm{x} 0$ well. 
The cross-shore propagation of simulated tidal fluctuations without capillary effects, hysteresis, or vertical layering is similar to the observed behavior. Specifically, the logarithm of the modeled amplitude attenuation is similar to that for the observations (Figure 3.5, compare dashed with solid lines). In addition, consistent with the observations (and with the intermediate depth theory), the slope of the simulated tidal phase lags with inland distance is smaller than that for the amplitude attenuation (compare dashed orange and pink lines in Figure 3.5b with those in Figure 3.5a). Discrepancies between the observed and simulated phase lags increase with inland distance, at least partly owing to difficulties fitting curves to the simulated groundwater head fluctuations that become small as the signal attenuates inland.

The simulated vertical phase structure also is similar to the observed structure and to that expected from the intermediate depth theory for $0>d>-10 \mathrm{~m}$ at both $\mathrm{x} 0$ and $\mathrm{x} 30$ (Figure 3.8). Similar to the model-data differences in the cross-shore propagation, discrepancies between the observed and modeled vertical phase structure partly may be owing to difficulties fitting curves to the simulated groundwater head fluctuations. The agreement of the simulated and observed crossshore and vertical structure of groundwater head fluctuations supports the conclusion that aquifer depth, rather than capillarity, hysteresis, or vertical layering, causes the discrepancy between $k_{i}$ and $k_{r}$ in the tidal propagation.

\subsection{Discussion}

\subsubsection{Estimating aquifer properties from ocean-driven head fluctuations}

Linear shallow aquifer theory and observations of ocean-forced groundwater head fluctuations have been used to estimate coastal-surface-aquifer diffusivity and to characterize 
regional aquifer structure (Erskine, 1991; Fakir \& Razack, 2003; Nielsen, 1990; Rotzoll \& ElKadi, 2008; Smith \& Hick, 2001; Trefry \& Bekele, 2004, and many others). Specifically, from (3) and (4) the diffusivity $D$, defined as $K z / S_{y}$, can be estimated from the inland amplitude attenuation rate or phase lag as:

$$
\begin{gathered}
D_{\text {amp }}=\frac{\pi}{\tau} \frac{x^{2}}{(\ln (a))^{2}} \\
D_{\text {phase }}=\frac{\pi}{\tau} \frac{x^{2}}{(\Delta \varphi)^{2}}
\end{gathered}
$$

Here the average diffusivity estimated from the 26 storm-driven amplitude attenuation rates $\left(D_{a m p}=6000 \mathrm{~m}^{2} / \mathrm{d}\right)$ and phase lags $\left(D_{\text {phase }}=8000 \mathrm{~m}^{2} / \mathrm{d}\right)$ approximately are consistent with each other and with the best fit diffusivity of the observed groundwater fluctuations with the intermediate depth theory $\left(K=60 \mathrm{~m} / \mathrm{d}, S_{y}=0.2, \mathrm{z}=20 \mathrm{~m}, \mathrm{D} \sim 6000 \mathrm{~m}^{2} / \mathrm{d}\right)$, and are in the middle of the range expected for the estimated hydrologic parameters for the aquifer $\left(15<K<90 \mathrm{~m} / \mathrm{d}, S_{y}=0.2,15<z\right.$ $<30 \mathrm{~m}$, implying $1000<D<13500 \mathrm{~m}^{2} / \mathrm{d}$ ). However, the variance of the estimated diffusivity values from individual storms is large (standard deviation $>5000 \mathrm{~m}^{2} / \mathrm{d}$ ), possibly resulting from applying a single wave period to the storm-driven signal. Observed storm-driven ocean shoreline water-level fluctuations consist of a broad spectrum of frequencies that will disperse and attenuate at different rates as they propagate through the aquifer. Applying analytical theories that include this dispersive effect, such as approximating the storms with a pulse model (Li et al., 2004), may yield a more consistent diffusivity estimate, but is outside the scope of this study.

The tidal amplitude-based diffusivity estimates (average diurnal and semi-diurnal $D_{a m p}$ are 8000 and $6000 \mathrm{~m}^{2} / \mathrm{d}$, respectively) are roughly consistent with the storm-based estimates. However, the tidal phase-based diffusivity estimates are larger than would be expected based on 
the theories (average diurnal and semi-diurnal $D_{\text {phase }}$ are 13000 and $9000 \mathrm{~m}^{2} / \mathrm{d}$, respectively), and are at the high end of the values expected from the estimated hydrogeological parameters. The values for amplitude- and phase-based diffusivity often are averaged to obtain a final estimate for aquifer diffusivity. The resulting estimates for this system are $\sim 11000$ (based on the propagation of the diurnal tide) and $~ 8000 \mathrm{~m}^{2} / \mathrm{d}$ (semi-diurnal tide), which are larger than that estimated from the storm propagation $\left(7000 \mathrm{~m}^{2} / \mathrm{d}\right)$. Diffusivities estimated from the numerical model simulations, in which $D$ is set to be $6000 \mathrm{~m}^{2} / \mathrm{d}$, are similar to those for the observed diurnal $\left(D_{a m p}=7000, D_{\text {phase }}\right.$ $\left.=11000 \mathrm{~m}^{2} / \mathrm{d}\right)$ and semi-diurnal $\left(D_{a m p}=7000, D_{\text {phase }}=10000 \mathrm{~m}^{2} / \mathrm{d}\right)$ tidal fluctuations.

These inconsistent amplitude and phase diffusivity estimates may be owing to violations of the shallow aquifer assumption, suggesting that it is important to determine whether the surface aquifer meets the shallow aquifer criterion $\left((k z)^{2}=S_{y} \omega z / K<<1\right)$ before using the Jacob-Ferris model to estimate aquifer properties. Similar aquifer characterization approaches can be applied in intermediate depth aquifers. If the aquifer is approximately homogeneous and the logarithm of the tidal amplitude attenuation and the phase evolution are linear with inland distance, diffusivity can be estimated by identifying the hydrologic parameters that yield the best fit to intermediate depth theory. Here, the combinations of $K$ and $z$ that give the best fit to the wavenumbers (or diffusivities) estimated from the observed amplitude attenuation and phase evolution for the semidiurnal tide correspond to $\mathrm{D}=\sim 4000-10000 \mathrm{~m}^{2} / \mathrm{d}$ (Figure 3.10), consistent with prior estimates at Duck. 

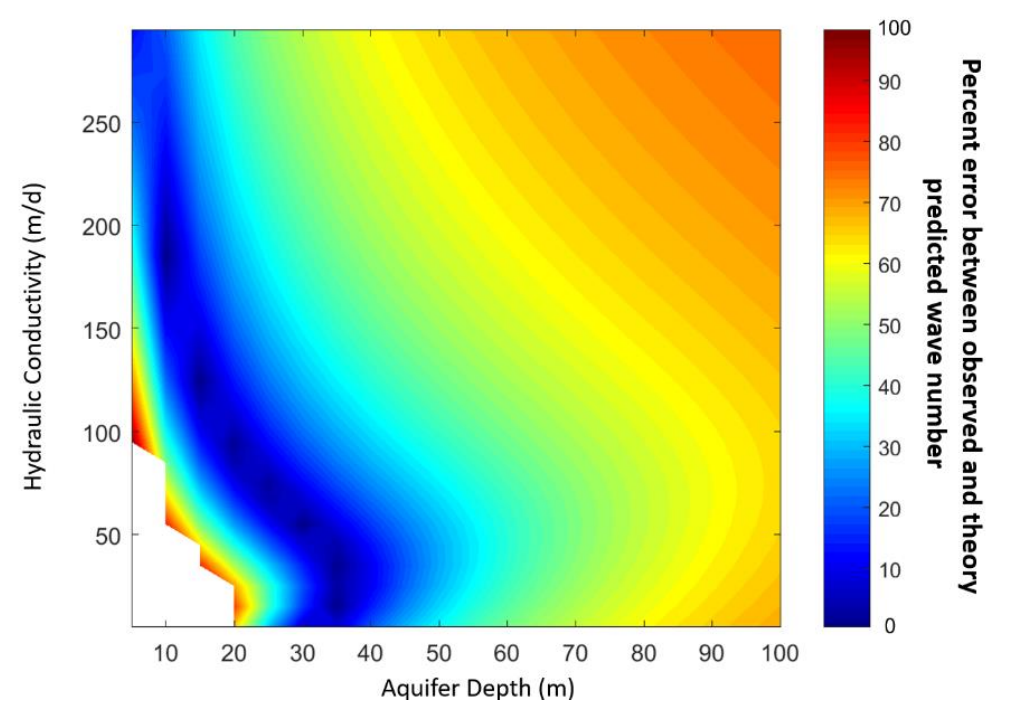

Figure 3.10: Magnitude of the difference between the wave number $\left(k=k_{r}+k_{i}\right)$ estimated from observations and from intermediate depth theory (Eq. 7, colors, scale on the right) normalized by the observational estimates as a function of hydraulic conductivity and aquifer depth (assuming $\left.S_{y}=0.2\right)$ for semi-diurnal tides $\left(\left|k_{\text {theory }}-k_{\text {observed }}\right| / k_{\text {observed }}\right.$ for each $\mathrm{K}, \mathrm{z}$ combination). Estimated parameters used for intermediate depth theory (Section 3.4) also included errors for diurnal tides and storms (not shown).

However, other processes and environmental factors such as capillarity, vertical layering, and variable aquifer depths can generate differences in the inland evolution of amplitudes and phases, and thus can result in different amplitude- and phase-based linear theory diffusivity estimates (Cartwright et al., 2005; Erskine, 1991; Fakir \& Razack, 2003; Nielsen et al., 1997; Raubenheimer et al. 1999; Shoushtari et al. 2015; Smith \& Hick, 2001; Trefry \& Bekele, 2004; Trefry \& Johnston, 1998). Furthermore, if there is complex stratigraphy or leakage between layers, the propagation analysis will not yield a linear trend (Jiao \& Tang, 1999; Trglavcnik et al. 2018). Consequently, it is important to consider both the depth regime and geologic environment when applying ocean-driven groundwater head fluctuation propagation to estimate aquifer parameters. 


\subsubsection{Inland heads, saline plumes, and estimating groundwater head fluctuations}

Scatter in the observed propagation of groundwater head fluctuations driven by ocean processes also may result from violations of other assumptions used to derive the dispersion relationships. As discussed above, including the neglected effects of capillarity and hysteresis on wave propagation (Barry et al., 1996; Cartwright et al., 2005; Li et al., 1997; Shoushtari et al., 2015) does not lead to better estimates of wavenumbers. Although the model fails to account for the temporal asymmetry of beach filling and draining (the beach fills more rapidly than it drains), these effects are expected to be confined primarily to the intertidal region.

Seasonal variations in recharge (rainfall), storm events, and sound water levels may influence the inland head-level and subsurface salinity structure (Heiss \& Michael, 2014; Robinson et al., 2014), potentially creating temporal and spatial variations in the effective aquifer depth that may modify tidal- and storm-driven head fluctuations. The variation in inland heads (less than

$2 \mathrm{~m}$ range) owing to these annual, seasonal, and storm processes is small relative to the aquifer depth $(\sim 20 \mathrm{~m})$, and numerical model results are insensitive to inland head levels (Dirichlet boundary condition) set to 0,1 (5\% increase in aquifer depth), and $2 \mathrm{~m}$ (10\% increase). However, estimates of fluctuation amplitudes can be sensitive to initial head distributions, which affect the minimum head levels. Specifically, ocean fluctuations primarily determine the maximum head level, so high initial inland heads result in smaller overall fluctuations, which can lead to underestimation of amplitudes and overestimation of attenuation rates. 
Although density gradients between the ocean and fresher terrestrially derived groundwater play an important role in groundwater dynamics at the aquifer-ocean interface, density gradients most strongly impact circulation and pressure gradients in the intertidal (Abarca et al., 2013; Heiss \& Michael, 2014; Robinson et al., 2006, 2007, 2014; Xin et al., 2010). Although neither the analytical nor the numerical model include density effects, plumes of saline water were measured at the $\mathrm{x} 0$ and $\times 30$ wells following several of the larger storms, and corresponding changes in the subsurface salinity structure could contribute to some of the variance in propagation behavior observed between events.

\subsubsection{Applications to other coastal systems}

Many prior studies of groundwater conducted in different global coastal settings would be estimated to be in the intermediate depth regime $\left(\mathrm{kz}^{2}>=0.1\right)$ for a semi-diurnal tide (e.g. Geng et al, 2017; Grekowiak 2014; Heiss \& Michael, 2014; Robinson et al., 2014). However, when applying these theories it is important to evaluate the assumptions applied in intermediate depth theory in relation to the hydraulic conditions at the field site. Intermediate depth theory assumes that the aquifer is homogeneous and isotropic (Nielsen 1997). In cases where there is subsurface heterogeneity amplitudes may not attenuate with distance from the coast because of constructive and destructive head fluctuation interactions between different aquifer layers and these solutions will not be valid (Trefry \& Bekele 2004; Trglavcnik et al., 2018). Capillarity can also generate slope factors less than one so additional terms may need to be incorporated in fine grained systems (Shoushtari et al. 2015). Non-linearities associated with beach slope have been previously observed to increase skewness and asymmetry in the intertidal zone, but were observed to not affect the propagation of head fluctuations in the intertidal (Raubenheimer et al. 1999). The 
derivation of intermediate depth theory also assumes that the amplitude of the fluctuation is small relative system. In shallow systems non-linearities generated by violating this assumption can significantly affect the propagation (Nielsen 1997). In mainland systems inland heads are often much higher resulting in a larger cross-shore variation in the aquifer depth that may also influence the propagation of head fluctuations. Despite these constraints, since sandy beaches account for more than $1 / 3$ of global coastlines these solutions are likely applicable in many other coastal systems (Vousdoukas et al., 2020).

\subsection{Conclusions}

Three years of observations of ocean water levels and groundwater heads in an approximately 20-m-deep barrier island surface aquifer were used to evaluate analytical theories for inland propagation of ocean shoreline fluctuations. The logarithm of the amplitude attenuation and the phase lag evolution for semi-diurnal-, diurnal-, and storm-driven fluctuations vary linearly with inland distance at rates increasing with fluctuation frequency (e.g., tides attenuate more rapidly than the longer-duration storm fluctuations), as expected for the approximately homogeneous aquifer. Differences between the tidal amplitude attenuation and phase lag rates are consistent with small amplitude, intermediate depth aquifer theory. In addition, tidal fluctuations near the surface of the aquifer lag those near the bottom, as expected in an intermediate depth aquifer. In contrast, the propagation of longer-period (lower frequency) storm-induced increases in ocean water levels is consistent with small amplitude, shallow aquifer (linear) theory. Numerical model simulations neglecting capillary effects, hysteresis, and vertical layering have tidal amplitude and phase evolution similar to those observed. Diffusivity estimates based on 
propagation of tidal groundwater fluctuations and small amplitude, linear shallow aquifer theory (Jacob-Ferris model) are larger than those based on the storm fluctuations, and tidal amplitudebased estimates are smaller than tidal phase-based estimates, similar to many prior results. However, diffusivities estimated from amplitude and phase evolution for tides and storms using intermediate depth theory are roughly consistent with each other, suggesting that large-scale aquifer properties can be estimated from fluctuations driven by ocean water-level changes using the appropriate theory.

\subsection{Acknowledgements}

We thank the USACE CHL-Field Research Facility for ocean and meteorological observations, and Levi Gorrell, Fred Marin, Emmett Krupczak, Bill Boyd, Paul Henderson, Heidi Wadman, Jesse McNinch, and Pat Dickhudt for assistance deploying and maintaining the groundwater wells. We also thank Clarissa Murray, Ann Mulligan, and James Heiss for assistance with MODFLOW. Funding was provided by the U.S. Coastal Research Program, the National Science Foundation, a National Science Foundation Graduate Research Fellowship, the Woods Hole Oceanographic ISP program, and National Security Science \& Engineering and Vannevar Bush Faculty Fellowships. 


\subsection{References}

Abarca, E., Karam, H., Hemond, H., \& Harvey, C. (2013). Transient groundwater dynamics in a coastal aquifer: The effects of tides, the lunar cycle, and the beach profile. Water Resources Research, 49(5), 2473-2488. https://doi.org/10.1002/wrcr.20075

Anderson, W. P. J., \& Lauer, R. M. (2008). The role of overwash in the evolution of mixing zone morphology within barrier islands. Hydrogeology Journal, 16(8), 1483-1495. https://doi.org/10.1007/s10040-008-0340-z

Bakhtyar, R., Brovelli, A., Barry, D. A., Robinson, C., \& Li, L. (2013). Transport of variabledensity solute plumes in beach aquifers in response to oceanic forcing. Advances in Water Resources, 53, 208-224. https://doi.org/10.1016/J.ADVWATRES.2012.11.009

Barry, D. A., Barry, S. J., \& Parlange, J.Y. (1996). Capillarity correction to periodic solutions of the shallow flow approximation. Coastal and Estuarine Studies, 50, 496-510. https://doi.org/10.1029/CE050p0496

Bedekar, V., Niswonger, R. G., Kipp, K., Panday, S., \& Tonkin, M. (2012). Approaches to the simulation of unconfined flow and perched groundwater flow in MODFLOW. Groundwater, 50(2), 187-198.

Boufadel, M. C., Li, H., Suidan, M. T., \& Venosa, A. D. (2007). Tracer studies in a laboratory beach subjected to waves. Journal of Environmental Engineering, 133(7), 722-732. https://doi.org/10.1061/(ASCE)0733-9372(2007)133:7(722)

Browder, A. G., \& McNinch, J. E. (2006). Linking framework geology and nearshore morphology: Correlation of paleo-channels with shore-oblique sandbars and gravel outcrops. Marine Geology, 231(1-4), 141-162. https://doi.org/10.1016/j.margeo.2006.06.006

Cartwright, N., Nielsen, P., \& Li, L. (2004). Experimental observations of watertable waves in an unconfined aquifer with a sloping boundary. Advances in Water Resources, 27(10), 9911004. https://doi.org/10.1016/J.ADVWATRES.2004.08.006

Cartwright, N., Nielsen, P., \& Perrochet, P. (2005). Influence of capillarity on a simple harmonic oscillating water table: Sand column experiments and modeling. Water Resources Research, 41(8). https://doi.org/10.1029/2005WR004023

Cartwright, N., \& Gibbes, B. (2011). Oceanic pulse forcing of a beach groundwater system. In Coasts and Ports 2011 : Diverse and Developing: Proceedings of the 20th Australasian 
Coastal and Ocean Engineering Conference and the 13th Australasian Port and Harbour Conference. 140. Engineers Australia.

Cartwright, N. (2014). Moisture-pressure dynamics above an oscillating water table. Journal of Hydrology, 512, 442-446.

Chardón-Maldonado, P., Pintado-Patiño, J. C., \& Puleo, J. A. (2016). Advances in swash-zone research: Small-scale hydrodynamic and sediment transport processes. Coastal Engineering, 115, 8-25. https://doi.org/10.1016/j.coastaleng.2015.10.008

Church, P. E., \& Granato, G. E. (1996). Bias in groundwater data caused by well-bore flow in long-screen wells. Groundwater, 34(2), 262-273. https://doi.org/10.1111/j.17456584.1996.tb01886.x

Dagan, G. (1967). Second-order theory of shallow free-surface flow in porous media. The Quarterly Journal of Mechanics and Applied Mathematics, 20(4), 517-526. https://doi.org/10.1093/qjmam/20.4.517

Elci, A., Molz, F. J., \& Waldrop, W. R. (2001). Implications of observed and simulated ambient flow in monitoring wells. Groundwater, 39(6), 853-862. https://doi.org/10.1111/j.17456584.2001.tb02473.x

Erskine, A. D. (1991). The effect of tidal fluctuation on a coastal aquifer in the UK. Groundwater, 29(4), 556-562. https://doi.org/10.1111/j.1745-6584.1991.tb00547.x

Fakir, Y., \& Razack, M. (2003). Hydrodynamic characterization of a Sahelian coastal aquifer using the ocean tide effect (Dridrate Aquifer, Morocco). Hydrological Sciences Journal, 48(3), 441-454. https://doi.org/10.1623/hysj.48.3.441.45281

Fenton, J. D. (1990). Calculating seepage flow with a free surface: Some old methods and some new ones. New Zealand Geomechanics Society Groundwater and Seepage Symposium.

Ferris, J. G. (1951). Cyclic fluctuations of water level as a basis for determining aquifer transmissibility. In: Assemblée générale de Bruxelles, tome II, 148-155. IAHS Publ. no. 33

Fofonoff, N., \& Millard, R.C. Jr. (1983). Algorithms for the computation of fundamental properties of seawater. Paris, France, UNESCO, 53pp. (UNESCO Technical Papers in Marine Sciences; 44), http://hdl.handle.net/11329/109

Guza, R. T., \& Thornton, E. B. (1981). Wave set-up on a natural beach. Journal of Geophysical Research, 86(C5), 4133. https://doi.org/10.1029/JC086iC05p04133 
Heiss, J. W., \& Michael, H. A. (2014). Saltwater-freshwater mixing dynamics in a sandy beach aquifer over tidal, spring-neap, and seasonal cycles. Water Resources Research, 50(8), 6747-6766.

Hunt, R. J., \& Feinstein, D. T. (2012). MODFLOW-NWT: Robust handling of dry cells using a Newton formulation of MODFLOW-2005. Groundwater, 50(5), 659-663.

Jacob, C. E. (1950). Flow of groundwater. Engineering Hydraulics, 321-386.

Jiao, J. J., \& Tang, Z. (1999). An analytical solution of groundwater response to tidal fluctuation in a leaky confined aquifer. Water Resources Research, 35(3), 747-751. https://doi.org/10.1029/1998WR900075

Kong, J., Shen, C. J., Xin, P., Song, Z., Li, L., Barry, D. A., et al. (2013).Capillary effect on water table fluctuations in unconfined aquifers. Water Resources Research, 49(5), 30643069. https://doi.org/10.1002/wrcr.20237

Kong, J., Xin, P., Hua, G. F., Luo, Z. Y., Shen, C. J., Chen, D., \& Li, L. (2015). Effects of vadose zone on groundwater table fluctuations in unconfined aquifers. Journal of Hydrology, 528, 397-407. https://doi.org/10.1016/J.JHYDROL.2015.06.045

Lautier, J. C. (2009). Hydrogeologic framework and groundwater conditions in the North Carolina East Central Coastal Plain. North Carolina Department of Environment and Natural Resources, Division of Water Resources, 2009.

Lazarus, E.D. and Murray, A.B (2011). An integrated hypothesis for regional patterns of shoreline change along the Northern North Carolina Outer Banks, USA. Marine Geology, 281(1-4), 85-90.

Levanon, E., Yechieli, Y., \& Shalev, E. (2013). Reliable monitoring of the transition zone between fresh and saline waters in coastal aquifers. 33(3), 101-110.

Groundwater. https://doi.org/10.1111/gwmr.12020

Li, L., Barry, D. A., Parlange, J. Y., \& Pattiaratchi, C. B. (1997). Beach water table fluctuations due to wave run-up: Capillarity effects. Water Resources Research, 33(5), 935-945. https://doi.org/10.1029/96WR03946

Li, L., Barry, D. A., Stagnitti, F., \& Parlange, J. Y. (2000). Groundwater waves in a coastal aquifer: A new governing equation including vertical effects and capillarity. Water Resources Research, 36(2), 411-420. https://doi.org/10.1029/1999WR900307

Li., L., Cartwright, N., Nielsen, P., \& Lockington, D. (2004). Response of coastal groundwater table to offshore storms. China Ocean Engineering, 18(3), 423-431. 
Longuet-Higgins, M. S., \& Stewart, R. W. (1964). Radiation stresses in water waves; a physical discussion, with applications. Deep-Sea Research, 11, 529-562.

Mallinson, D.J., Smith, C.W., Culver, S.J., Riggs, S.R. \& Ames, D (2010). Geological characteristics and spatial distribution of paleo-inlet channels beneath the outer banks barrier islands, North Carolina, USA. Estuarine, Coastal and Shelf Science, 88(2), 175-189.

Manahan, S., Martin, W. K., \& Guo, W. (1998). Dare County-wide hydrogeological study and groundwater resource evaluation. Dare County Water Production Department, Kill Devil Hills, NC.

Meisburger, E. P., Williams, S. J., \& Judge, C. (1989). Physiographic and geological setting of the Coastal Engineering Research Center's Field Research Facility. Vicksburg, MS.

Moore, W. S. (2010). The effect of submarine groundwater discharge on the ocean. Annual Review of Marine Science, 2(1), 59-88. https://doi.org/10.1146/annurev-marine-120308081019

Mulligan, A. E., Langevin, C., \& Post, V. E. A. (2011). Tidal boundary conditions in SEAWAT. Groundwater, 49(6), 866-879. https://doi.org/10.1111/j.1745-6584.2010.00788.x

Nielsen, P. (1988). Wave setup: A field study. Journal of Geophysical Research, 93(C12), 15643. https://doi.org/10.1029/JC093iC12p15643

Nielsen, P. (1990). Tidal dynamics of the water table in beaches. Water Resources Research, 26(9), 2127-2134. https://doi.org/10.1029/WR026i009p02127

Nielsen, P., Aseervatham, R., Fenton, J. D., \& Perrochet, P. (1997). Groundwater waves in aquifers of intermediate depths. Advances in Water Resources, 20(1), 37-43. https://doi.org/10.1016/S0309-1708(96)00015-2

Nielsen, P., \& Perrochet, P. (2000a). Watertable dynamics under capillary fringes: experiments and modelling. Advances in Water Resources, 23(5), 503-515. https://doi.org/10.1016/S0309-1708(99)00038-X

Nielsen, P., \& Perrochet, P. (2000b). ERRATA: Watertable dynamics under capillary fringes: experiments and modeling [Advances in Water Resources 23 (2000) 503-515]. Advances in Water Resources, 23(8), 907-908.

Nielsen, P., \& Turner, I. (2000). Groundwater waves and water exchange in beaches. In 27th International Conference on Coastal Engineering. Sydney, NSW, Australia: American Society of Civil Engineers. 
Niswonger, R. G., Panday, S., \& Motomu, I. (2011). MODFLOW-NWT, A Newton formulation for MODFLOW-2005: U.S. Geological Survey Techniques and Methods 6-A37.

Parlange, J., Stagnitti, F., Starr, J., \& Braddock, R. (1984). Free-surface flow in porous media and periodic solution of the shallow-flow approximation. Journal of Hydrology, 70, 251263.

Post, V. E. A. (2011). A new package for simulating periodic boundary conditions in MODFLOW and SEAWAT. Computers and Geosciences, 37(11), 1843-1849. https://doi.org/10.1016/j.cageo.2011.01.012

Raubenheimer, B., Guza, R. T., \& Elgar, S. (1999). Tidal water table fluctuations in a sandy ocean beach. Water Resources Research, 35(8), 2313-2320. https://doi.org/10.1029/1999WR900105

Raubenheimer, B., Guza, R. T., \& Elgar, S. (2001). Field observations of wave-driven setdown and setup. Journal of Geophysical Research: Oceans, 106(C3), 4629-4638. https://doi.org/10.1029/2000JC000572

Riggs, S. R., Cleary, W. J., \& Snyder, S. W. (1995). Influence of inherited geologic framework on barrier shoreface morphology and dynamics. Marine Geology, 126(1-4), 213-234. https://doi.org/10.1016/0025-3227(95)00079-E

Robinson, C., Gibbes, B., \& Li, L. (2006). Driving mechanisms for groundwater flow and salt transport in a subterranean estuary. Geophysical Research Letters, 33(3), L03402. https://doi.org/10.1029/2005GL025247

Robinson, C., Li, L., \& Prommer, H. (2007). Tide-induced recirculation across the aquifer-ocean interface. Water Resources Research, 43(7). https://doi.org/10.1029/2006WR005679

Rotzoll, K., \& El-Kadi, A. I. (2008). Estimating hydraulic properties of coastal aquifers using wave setup. Journal of Hydrology, 353(1), 201-213. https://doi.org/10.1016/i.jhydrol.2008.02.005

Robinson, C., Xin, P., Li, L., \& Barry, D. A. (2014). Groundwater flow and salt transport in a subterranean estuary driven by intensified wave conditions. Water Resources Research, 50(1), 165-181. https://doi.org/10.1002/2013WR01381

Shoushtari, S. M. H. J., Cartwright, N., Perrochet, P., \& Nielsen, P. (2015). Influence of hysteresis on groundwater wave dynamics in an unconfined aquifer with a sloping boundary. Journal of Hydrology, 531, 1114-1121. https://doi.org/10.1016/J.JHYDROL.2015.11.020 
Shoushtari, S. M. H. J., Cartwright, N., Nielsen, P., \& Perrochet, P. (2016). The effects of oscillation period on groundwater wave dispersion in a sandy unconfined aquifer: Sand flume experiments and modelling. Journal of Hydrology, 533, 412-420. https://doi.org/10.1016/J.JHYDROL.2015.12.032

Smith, A. J., \& Hick, W. P. (2001). Hydrogeology and aquifer tidal propagation in Cockburn Sound, Western Australia.

Sous, D., Lambert, A., Rey, V., \& Michallet, H. (2013). Swash-groundwater dynamics in a sandy beach laboratory experiment. Coastal Engineering, 80, 122-136. https://doi.org/10.1016/j.coastaleng.2013.05.006

Teo, H. T., Jeng, D. S., Seymour, B. R., Barry, D. A., \& Li, L. (2003). A new analytical solution for water table fluctuations in coastal aquifers with sloping beaches. Advances in Water Resources, 26(12), 1239-1247. https://doi.org/10.1016/j.advwatres.2003.08.004

Trefry, M. G., \& Johnston, C. D. (1998). Pumping test analysis for a tidally forced aquifer. Groundwater, 36(3), 427-433. https://doi.org/10.1111/j.1745-6584.1998.tb02813.x

Trefry, M. G., \& Bekele, E. (2004). Structural characterization of an island aquifer via tidal methods. Water Resources Research, 40(1). https://doi.org/10.1029/2003WR002003

Trglavcnik, V., Morrow, D., Weber, K. P., Li, L., \& Robinson, C. E. (2018). Analysis of tide and offshore storm-induced water table fluctuations for structural characterization of a coastal island aquifer. Water Resources Research, 54(4), 2749-2767. https://doi.org/10.1002/2017WR020975

Turner, I. L., \& Masselink, G. (1998). Swash infiltration-exfiltration and sediment transport. Journal of Geophysical Research: Oceans, 103(C13), 30813-30824. https://doi.org/10.1029/98JC02606

Werner, A. D., \& Lockington, D. A. (2003). Influence of hysteresis on tidal capillary fringe dynamics in a well-sorted sand. Advances in Water Resources, 26(11), 1199-1204. https://doi.org/10.1016/S0309-1708(03)00107-6

Winner, M. D. J., \& Coble, R. (1996). Hydrogeologic framework of the North Carolina Coastal Plain.

Xin, P., Robinson, C., Li, L., Barry, D. A., \& Bakhtyar, R. (2010). Effects of wave forcing on a subterranean estuary. Water Resources Research, 46(12). https://doi.org/10.1029/2010WR009632 


\title{
Chapter 4:
}

\section{Flooding owing to high groundwater driven by rain and shoreline water levels}

\begin{abstract}
Flooding of barrier islands, which often is associated with coastal storms, has negative societal and economic impacts. Here, three years of observations of groundwater elevations, ocean tides, surge, waves, and rainfall collected near Duck, NC, and citizen-science flood reports on the North Carolina Outer Banks are used to study coastal groundwater-driven flooding. Increases in ocean surge and wave-driven water levels (setup) during storms, including the passage of 4 hurricanes, caused $O(1 \mathrm{~m})$ increases in groundwater heads under the dunes on the ocean side of the barrier island. The inland propagation of the resulting pulse in groundwater levels is consistent with shallow aquifer theory. Infiltration of precipitation results in approximately a threefold increase in the groundwater level relative to the amount of rainfall. An analytical water-table evolution model driven with estimated ocean shoreline water levels (based on the 36-hr-averaged offshore tide, surge, and wave height) and measured precipitation predicts the maximum watertable height within $0.1 \mathrm{~m}$ of the observed levels across the barrier island.

Citizen-science reports from a smartphone app (iFlood) developed to obtain flood information throughout the Outer Banks region are used to evaluate the model. Twenty-five oceanside reports associated with 7 storms between Sept 2019 and Feb 2020 showed flooding on natural (permeable) land surfaces along $70 \mathrm{~km}$ of the Outer Banks, from Corolla to Rodanthe, NC. The analytical model predicts flooding that is consistent with the timing and location for 19 of the 25 reports. Applying the model regionally suggests that more than $10 \%$ of the land area on the ocean-
\end{abstract}


side of the northern Outer Banks would be inundated by coastal groundwater even in the absence of rainfall for a storm that generates a $2.25 \mathrm{~m}$ increase in the shoreline water level

\subsection{Introduction}

Nearly 1.5 million people inhabit barrier islands along the U.S. Atlantic and Gulf Coasts with a population density that is approximately three times greater than that of coastal states (Zhang \& Leatherman, 2011) and that is increasing, along with the associated infrastructure (Elko et al., 2015). The low elevations (close to mean sea level, MSL) and high density of infrastructure make coastal counties susceptible to devastating environmental and economic impacts from flooding. As of 2019, the U.S. National Flood Insurance Program was $~ \$ 20$ billion dollars in debt (Horn \& Webel, 2019). Sea-level rise and the increasing strength and duration of storms are predicted to double the frequency of flooding and to expand the spatial extent of flood impacts (Befus et al., 2020; Knutson et al., 2020; Moftakhari et al., 2015; Patricola \& Wehner, 2018; Sweet et al., 2020 Vitousek et al., 2017; Woodruff et al., 2013). Compound flooding driven by multiple hazards, such as rain and storm surge, can magnify the duration and extent of flood impacts (Bevacqua et al., 2019; Wahl et al., 2015).

In unconfined coastal aquifers, the average water table usually is higher than MSL and lies within a few meters of the land surface in low relief regions (Befus et al., 2020; Glover, 1959; Rotzoll \& Fletcher, 2013;). During multi-hazard storm events, the elevation of the coastal water table fluctuates in response to changes in the oceanic forcing and to infiltration from rainfall. Although groundwater can cause flooding if the water table exceeds the land surface, groundwater processes typically are neglected in flood hazard mapping and management policies (Abboud et al., 2018; Morris et al., 2007; Rotzoll \& Fletcher, 2013). Developing flood predictions that 
integrate oceanographic, meteorological, and hydrogeological processes has been identified as a research need for managing storm hazards and impacts (Elko et al., 2019).

During extreme events, storm surge and large waves can increase the shoreline water level by several meters. The coastal aquifer is hydraulically connected to the ocean, and thus the water table fluctuates in response to wave-, tide-, and surge-driven changes in the ocean water level (Abarca et al., 2013; Anderson \& Lauer, 2008; Cartwright et al., 2004; Nielsen, 1990;). The resulting storm pulse increases the elevation of the coastal water table, and this bulge of high groundwater continues to propagate inland after the storm has subsided (Li et al., 2004; Rotzoll \& El-Kadi, 2008). Storm pulses have larger amplitudes and longer fluctuation periods than water-table oscillations driven by waves or tides and thus can penetrate farther into the aquifer (Li et al., 2004; Nielsen, 1990). As the storm signal propagates inland, the amplitude of the fluctuation attenuates at a rate controlled by the hydrogeologic properties and structural composition of the aquifer (Li et al., 2004; Rotzoll \& El-Kadi, 2008). An analytical solution for the propagation of storm-driven groundwater fluctuations assuming a vertical beach face and a homogeneous, isotropic, uniformdepth aquifer reproduced the behavior of a storm-induced groundwater fluctuation in a sandy aquifer in a coastal barrier island for a single event (Cartwright et al., 2004; Li et al., 2004).

When rainfall is coincident with emergent groundwater from the land surface, the duration of the flood tends to last longer than runoff- or overwash-driven flooding alone (Befus et al., 2020; MacDonald et al., 2008). The water table rises in response to infiltration from precipitation by an amount inversely dependent on the effective porosity of the aquifer (Crosbie et al., 2005; Cobby et al., 2009; Meinzer, 1923; Smail et al., 2019; Zhang et al., 2017). Antecedent conditions that 
result in an elevated water table reduce the aquifer infiltration capacity for subsequent events (Rotzoll \& Fletcher, 2013).

Here, three years of continuous observations (Section 4.2) near Duck, NC are used to develop a field-calibrated analytical model (Section 4.3) for the groundwater level in the unconfined surface aquifer driven by changes in the shoreline water level and rainfall. Flood reports submitted to iFlood (Section 4.1), a citizen-science phone application, are used to conduct a hindcast assessment of the analytical groundwater-flooding model along a 70-km region of the Outer Banks between Corolla and Rodanthe, NC (Section 4.2). The analytical flooding model is used to predict regions of groundwater flood vulnerability on the ocean-side of the Outer Banks caused by an increase in the shoreline water level consistent with a hurricane or large Nor'easter (Section 4.3).

\subsection{Field Measurements}

\subsubsection{Site Description}

The North Carolina Outer Banks is a 320-km long chain of barrier islands extending south from the Virginia-North Carolina state line to Bogue Inlet. The islands are up to 3-km wide, and have ocean-shoreline dunes from less than 1- to 12-m high (Elko et al., 2002). The North Carolina Outer Banks is part of the North Carolina Coastal Plain aquifer system, and the shallow geology is a 50-70 m thick Quaternary sequence that fills the Albemarle Embayment (Lautier, 2009; Winner \& Coble, 1996). The surficial aquifer typically is comprised of $>70 \%$ sand (Winner $\&$ Coble, 1996). A network of paleo-channels that were backfilled with younger Pleistocene sediments also weaves through the Quartenary sequence (Lazarus \& Murray, 2011; Riggs et al., 1995). The paleo-channels contain muddy estuarine sediment, sand, and fluvial gravel (Lazarus \& Murray, 2011). Branches of the paleo-Roanoke/Albemarle fluvial system have been recorded at 
the shoreface in Duck, Kitty Hawk, Kill Devil Hills, and Nags Head (Boss et al., 2002; Lazarus \& Murray, 2011; Riggs et al., 1995;). The surficial aquifer is underlain by a series of discontinuous clay and silt beds that comprise the Yorktown confining unit, which is estimated to occur $15-20 \mathrm{~m}$ below NAVD88 (approximately mean sea level) (Mallinson et al., 2010; Winner \& Coble, 1996). In September 2014, 19 groundwater wells were installed at 8 locations along a 550-m-long transect across the barrier island extending from the ocean dune to the sound at the U.S. Army Corps of Engineers Coastal Hydraulics Laboratory Field Research Facility (FRF, http://www.frf.usace.army.mil) in Duck, NC (Figure 4.1). The property is bordered on the west by Currituck Sound and on the east by the Atlantic Ocean. On the ocean-side of the island, the beach is backed by $\sim 7-\mathrm{m}$-high vegetated dunes. Sediment samples collected during construction of the FRF facility (Meisburger et al., 1989) and during installation of the groundwater wells suggest that the surficial aquifer is composed of medium quartz sand (mean diameter $\sim 0.25 \mathrm{~mm}$ ) and shell hash. Prior studies suggest the uppermost confining layer is roughly 15 to $30 \mathrm{~m}$ below NAVD88 (Meisburger et al., 1989; Manahan et al., 1998). However, a confining unit was not encountered during drilling, with boreholes extending from 15 (under the dune) to $26 \mathrm{~m}$ (near the sound) below NAVD88. Slug tests (Bouwer \& Rice, 1976; Brown et al., 1995; Butler et al., 1996; Hvorslev, 1951) performed at 16 of the wells spanning the island suggest that the hydraulic conductivity is approximately $K=13.0 \pm 4.4 \mathrm{~m} / \mathrm{d}$, consistent with an estimate of $14.9 \mathrm{~m} / \mathrm{d}$ obtained during drilling of a test water supply well about 2 miles south of the study site (Manahan et al., 1998). Based on these observations, the aquifer is assumed to be approximately uniform across the island. 

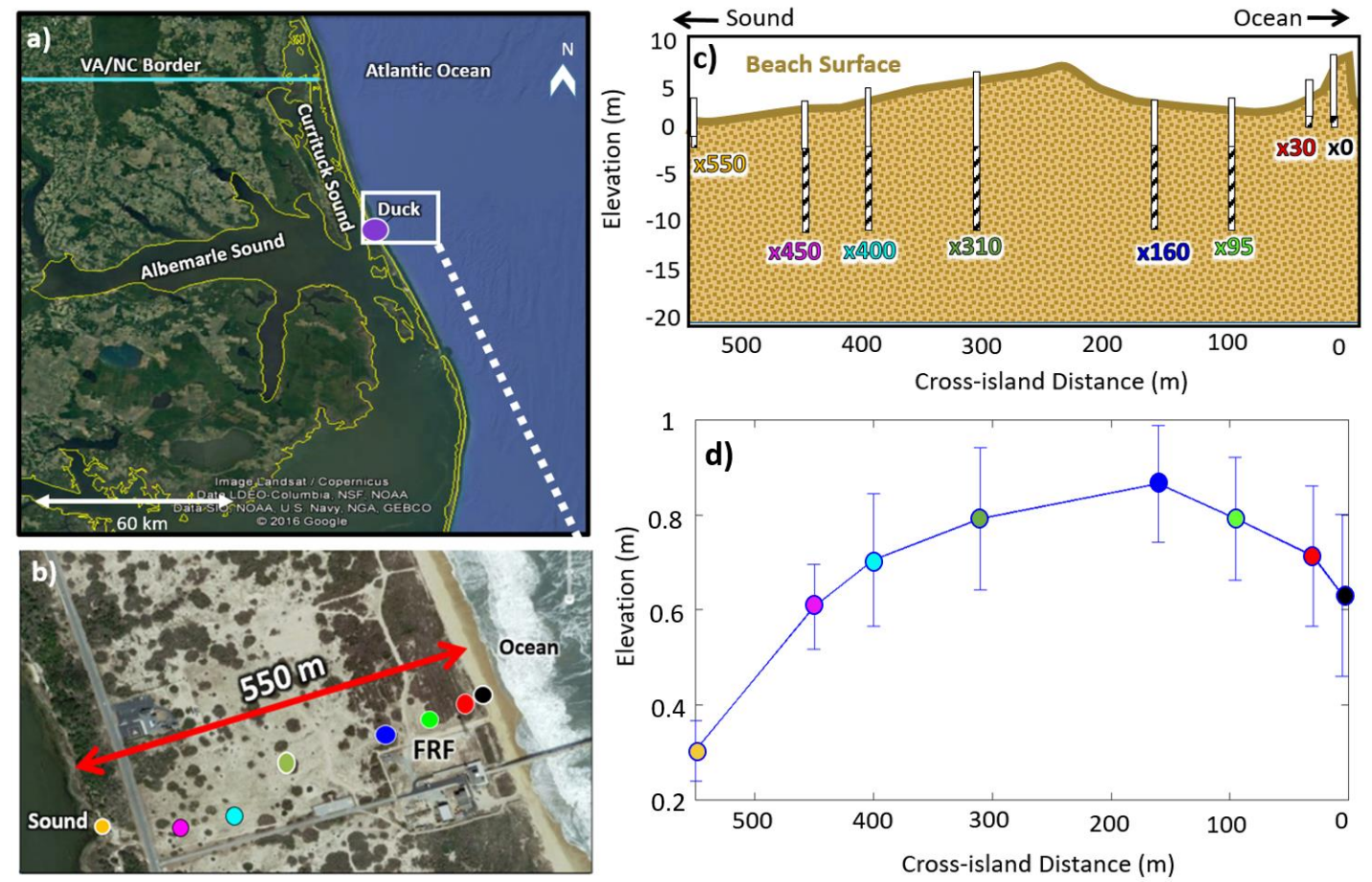

Figure 4.1: a) Google Earth image of northeastern North Carolina, including the Outer Banks. The land is outlined in yellow. The U.S. Army Corps of Engineers Field Research Facility (FRF, purple circle in the white box), Duck, NC is located on a barrier island between Currituck Sound and the Atlantic Ocean. b) Close-up view of the barrier island showing the locations of groundwater wells (colored circles) extending from the ocean dune to the sound. c) Elevation of the beach surface (tan curve) relative to NAVD88 and groundwater wells (long, thin white rectangles) versus distance from the well closest to the ocean. The cross-hatched region on each well is the screened section. d) Annual average water-table elevation versus cross-island distance. The vertical bars represent 1 standard deviation.

\subsubsection{Observations}

The cross-shore positions ( $x$, positive toward the sound) of the well locations are defined relative to the well closest to the dune face. Each well was composed of $0.05 \mathrm{~m}$-diameter PVC 
pipe with No.10 perforated screen at the bottom surrounded by gravel pack topped with a bentonite seal. At the six mid-island locations (Figure 4.1c, $95 \leq x \leq 450 \mathrm{~m}$ ), where salinities are $<1$ PSU, wells extended 9 to $10 \mathrm{~m}$ below NAVD88 with 8- to 9-m-long screens. Near the ocean (Figure 4.1b, red and black circles) and sound (Figure 4.1b, orange circle), wells (Figure 4.1c) extended to about $1 \mathrm{~m}$ below NAVD88 with 0.6-m-long screens (Figure 4.1c). Conductivity-temperaturedepth (CTD) sensors at about mid-screen-elevation in each well were sampled at 10-min intervals. Water density was calculated from the measured salinity, temperature, and pressure (Fofonoff $\&$ Millard, 1983). The sensors were vented to the atmosphere so that pressure measurements were not influenced by fluctuations in barometric pressure. Sensor elevations were estimated using differential GPS measurements of the well cap, and simultaneous water-level measurements (from a standard meter) and pressure and water density measurements from the in situ sensors. Annual re-estimates show less than $0.02 \mathrm{~m}$ drift. Water table elevations were estimated from the pressure measurements converted to equivalent freshwater head $h_{f}$ as,

$$
h_{f}=\frac{p}{\rho_{f} g}+z_{s}
$$

where $p(\mathrm{~Pa})$ is the measured pressure, $\rho_{f}\left(\mathrm{~kg} / \mathrm{m}^{3}\right)$ is the density of freshwater, $g\left(\mathrm{~m} / \mathrm{s}^{2}\right)$ is the gravitational constant, and $z_{s}(\mathrm{~m})$ is the elevation of the sensor (relative to NAVD88).

Ocean water levels were measured every 6 min with a NOAA tide gauge (ID 8651371) in about $6 \mathrm{~m}$ depth at the end of the FRF pier. Tides were semi-diurnal with range $\sim 1 \mathrm{~m}$ and storm surge was up to $\sim 1 \mathrm{~m}$. Significant wave heights $\left(H_{s}, 4\right.$ times the standard deviation of sea-surface elevation fluctuations in the frequency range from 0.05 to $0.30 \mathrm{~Hz}$ ) recorded every $30 \mathrm{~min}$ in 26$\mathrm{m}$ water depth (NDBC Station 44100) ranged from near 0 to $6 \mathrm{~m}$ (Figure 2a), with an average of 
about $1 \mathrm{~m}$. Breaking wave-driven setup (Longuet-Higgins \& Stewart, 1964) of the shoreline water levels is estimated to be 0.2 times the offshore significant wave height (Guza \& Thornton, 1981; Nielsen, 1988; Raubenheimer et al., 2001), roughly consistent with observations from a LIDAR on the dune about $300 \mathrm{~m}$ north of the wells. Shoreline water levels are estimated as the sum of the ocean water level (including tides and surge) and the setup.

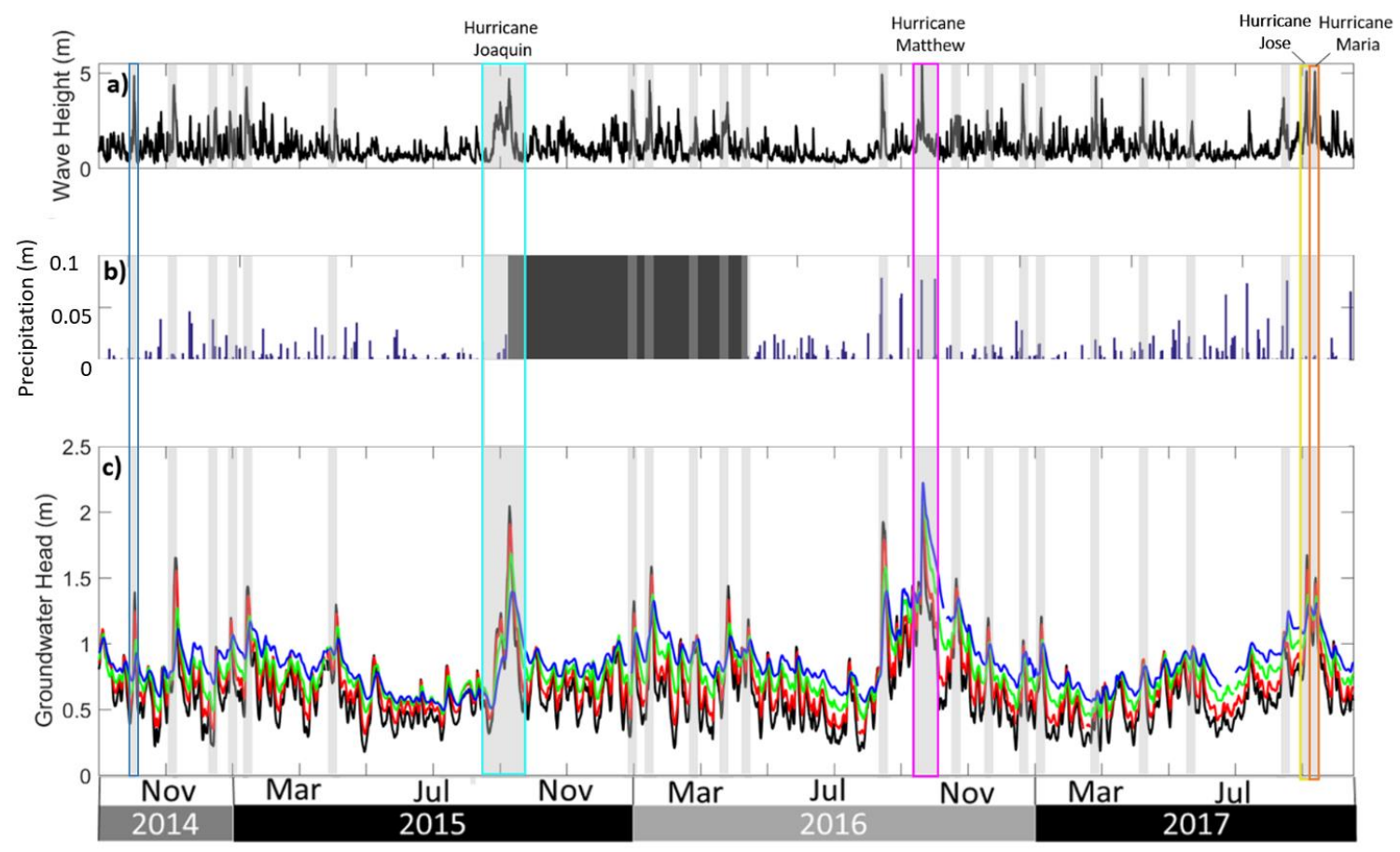

Figure 2: a) Significant wave height, b) precipitation, and c) 36-hr. average freshwater equivalent groundwater head ( $x=0,30,95,160 \mathrm{~m}$, black, red, green, blue curves) versus time. Colored boxes identify periods with impacts from a nor'easter (dark blue, Oct. 2014) and Hurricanes Joaquin (light blue, Oct. 2015), Matthew (magenta, Oct. 2016), Jose (yellow, Sept. 2017) and Maria (orange, Sept. 2017). Grey vertical bars indicate the 27 storms during the 3 -yr period. The precipitation gauge was not operational between Sept. 2015 and May 2016 (black box 2b).

Storms are defined as events with combined 36-hr averaged (de-tided) shoreline water level exceeding $0.65 \mathrm{~m}$ above NAVD88. Twenty-seven storm events were observed during the 3-year data record, including 4 hurricanes that passed offshore of Duck, NC (Joaquin, Oct. 2015 (cyan box, Figure 4.2), Matthew, Oct. 2016 (magenta box, Figure 4.2), and Jose and Maria, Sept. 2017 
(yellow and orange boxes, Figure 4.2, respectively)). With the exception of Hurricane Matthew, there was $<0.05 \mathrm{~m}$ rainfall during the storms.

Precipitation (Figure 4.2b) was recorded every 10 min using a set of 3 rain gauges. Data from the precipitation gauges is uncertain during extreme rainfall rates $(>0.03 \mathrm{~m} / \mathrm{hr})$, which only occurred once in the observation period (during Hurricane Matthew, Oct. 2016). Tidal effects were negligible in the sound, but winds can drive rapid 1-2 m changes in the sound water level (Mulligan et al., 2014). Low sound water levels typically occur during the winter months (Caldwell, 2001) and often are coincident with high ocean water levels driven by winter storms. Under calm conditions the ocean-side groundwater heads increase landward (Figures 1d and 2c, blue and green curves are higher than red and black curves, e.g., May-July 2015), and the water table is highest $\sim 160 \mathrm{~m}$ inland from the dune (Fig. 4.1c, d). The average head gradient between the center of the island and the ocean well (x0) is $0.0015 \mathrm{~m} / \mathrm{m}$ (Fig. 4.1d). However, during storms, surge, setup, and wave infiltration result in the groundwater head at the wells closest to the ocean exceeding the head levels at the inland wells (Figure 4.2c, shaded grey areas, and Figure 4.3). The bulge of high groundwater attenuates as it propagates inland (Figure 4.3b). 

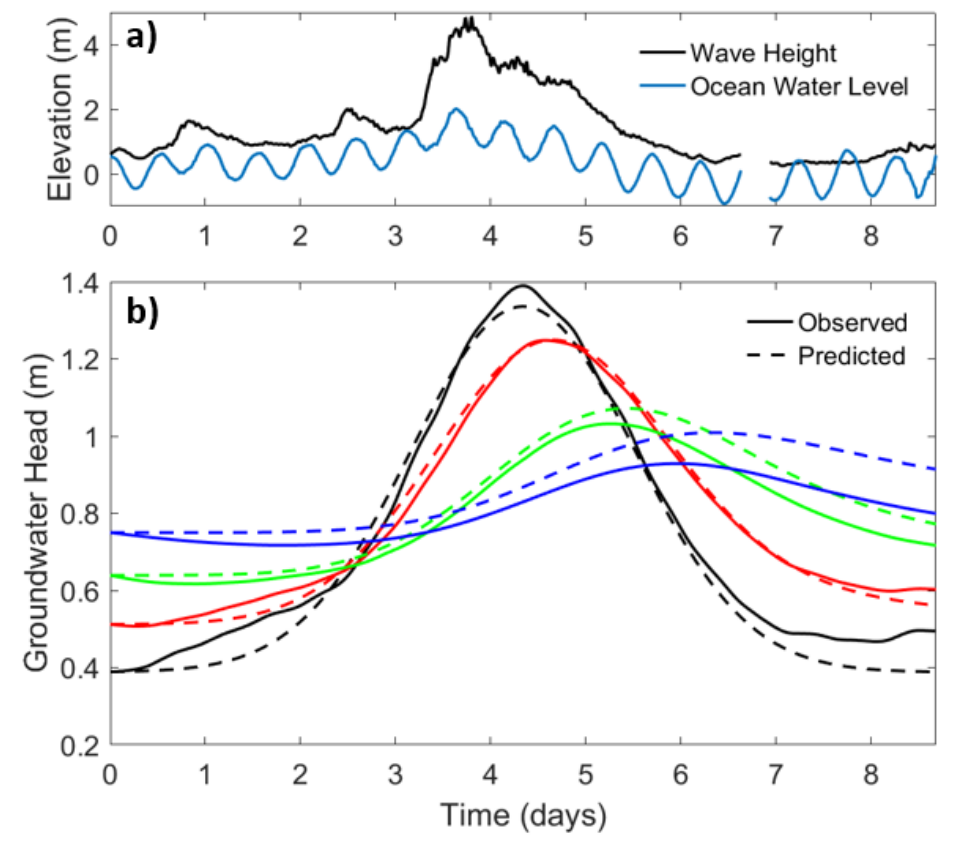

Figure 4.3: a) Significant wave height (black) and ocean water level (blue) and b) 36-hr average freshwater equivalent groundwater head observed (solid curves) and predicted using pulse theory (Li et al. 2004, dashed curves) with $\mathrm{D}=3500 \mathrm{~m}^{2} / \mathrm{d}$ versus time for a single nor'easter (dark blue box Figure 2) at $\mathrm{x}=0,30,95,160 \mathrm{~m}$ (black, red, green, blue curves).

The two storms that resulted in the highest groundwater levels at $\mathrm{x} 0$ were Hurricane Joaquin (cyan box, Figure 4.2) and Hurricane Matthew (magenta box, Figure 4.2). A nor'easter preceded Hurricane Joaquin and caused sustained elevated offshore wave heights. Soon after the nor'easter, Hurricane Joaquin developed in the Atlantic and generated a second series of large waves that reached maximum heights of $4.7 \mathrm{~m}$ in 26-m water depth on October 5, 2015. Head levels increased 1.6, 1.4, 1.2, $0.9 \mathrm{~m}$ above pre-storm levels during Hurricane Joaquin at x=0, 25, 90, and $160 \mathrm{~m}$ respectively (Figure 4.2c) and $0.5 \mathrm{~m}$ at $\mathrm{x}=310 \mathrm{~m}$ (not shown). When the high water levels from Hurricane Joaquin propagated inland, the water table came within approximately $1 \mathrm{~m}$ of the ground surface at $\mathrm{x} 95$ and $\times 160$. Following Hurricane Joaquin, the water table at $x 160$ took 
approximately two weeks to return to within a standard deviation of the average level. The time delays between the occurrences of maximum water levels at each well location indicate an inland propagation rate of the storm-driven groundwater bulge of about $60 \mathrm{~m} / \mathrm{day}$.

During Hurricane Matthew, infiltration from heavy precipitation (>0.2 m, FEMA 2018

Table 3) and increasing ocean water levels both contributed to the increase in the water table. Instead of a delayed response in the time of arrival of the maximum water level, a near simultaneous 0.6 to $0.9 \mathrm{~m}$ increase in groundwater level occurred at all well locations (Figure 4.2) following the heavy precipitation.

\subsection{Analytical Model}

\subsubsection{Groundwater-Pulse Theory Evaluation}

Propagation of the storm-driven groundwater pulse is simulated using an analytical solution (Li et al., 2004) for Darcian groundwater flow assuming a Gaussian shoreline fluctuation (pulse) and applying a linearization based on the assumption that the amplitude of the water-table fluctuation is small relative to the depth of the aquifer (see Appendix). Here, the propagation is driven (Equation (A1)) with the head fluctuations at the $\mathrm{x} 0$ well rather than with the shoreline fluctuations to avoid errors resulting from uncertainty in the cross-shore position of the shoreline, which changes with changing ocean water levels on the sloping beach, with evolving beach topography during storms (up to $4 \mathrm{~m}$ erosion during a single event), with seasons (the mean shoreline position can vary 10 s of meters as the beach accretes during the summer and erodes during the winter), and with long-term trends (the dune eroded more than $10 \mathrm{~m}$ landward during 
the observation period). Data from the four wells closest to the ocean (x0-x160) during the 26 storms with minimal rainfall are included in the evaluation of the pulse theory.

Using the observed amplitude decay and phase evolution, the best-fit diffusivity for storm pulses is $D=3500 \mathrm{~m}^{2} / \mathrm{d}$, which is within a factor 2 of the diffusivity based on the estimated hydrologic parameters (hydraulic conductivity $K=13 \mathrm{~m} / \mathrm{d}$, specific yield $S_{y}=0.2$, and the aquifer depth $z=30 \mathrm{~m})$. The resulting non-dimensional amplitude attenuation $\alpha$ and phase lag $\Delta \phi^{*}$ (Equations $\mathrm{A} 4, \mathrm{~A} 5)$ agree well $\left(\mathrm{R}^{2}\right.$ of 0.73 and 0.71 , respectively) with the analytical solution (Figure 4.4). The agreement between theory and data is insensitive to cross-shore distance, consistent with the assumption that the aquifer at Duck is approximately homogeneous and isotropic (Li et al. 2004). The root mean square error (RMSE) between the analytical maximum water table and the measurements is $\sim 0.1 \mathrm{~m}$ at all locations for all storms, and the estimated timing of the maximum water level is correct to within 0.5 days (Figure 4.3 shows an example for a single storm). After the storm peak, the RMSE error between the observed and theoretical groundwater level increases to $\sim 0.3 \mathrm{~m}$, possibly because the fluctuations in the shoreline water level are not always Gaussian. The fits between the 26 observed storm pulses and a Gaussian shape had correlations $\mathrm{R}^{2}>0.9$ (Appendix), although 5 storms were negatively skewed, and 10 storms were positively skewed, with 5 skewness magnitudes greater than 0.3 . 


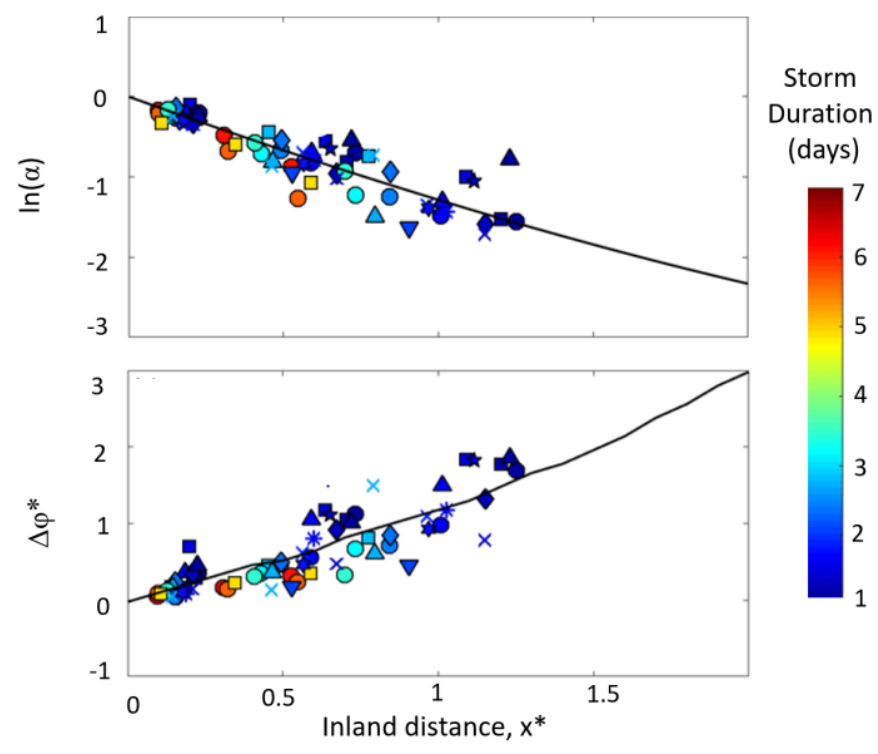

Figure 4.4: Observed (symbols) and theoretical (black curves, Li et al., 2004, Equation A2) a) non-dimensional amplitude attenuation and b) phase change versus normalized inland distance. Symbol shapes correspond to different storms $(n=26)$, with colors corresponding to storm duration (color scale on the right). The squared correlation $\mathrm{R}^{2}$ between observations and theory is 0.73 and 0.71 for amplitude attenuation and phase change, respectively.

\subsubsection{Precipitation Response}

The groundwater data on the sound side of the island (x310-x550, Figure 4.1), where ocean-driven groundwater fluctuations are typically negligible under low wave conditions, are used to determine the water-table response to precipitation events. Rainfall events between Oct 2014 and Oct 2016, during periods when offshore ocean wave heights were less than $2 \mathrm{~m}(n=32)$, were included in the analysis. Periods of longer than two days without rainfall are used to separate rainfall events. A linear regression of the groundwater level change as a function of the total rainfall for each event suggests the water table increase is approximately three times the amount of rainfall at all sites (Figure 4.5 shows an example for $\mathrm{x}=310,400$, and $450 \mathrm{~m}$ ), consistent with an effective porosity $n_{e}$ of about 0.33 . 


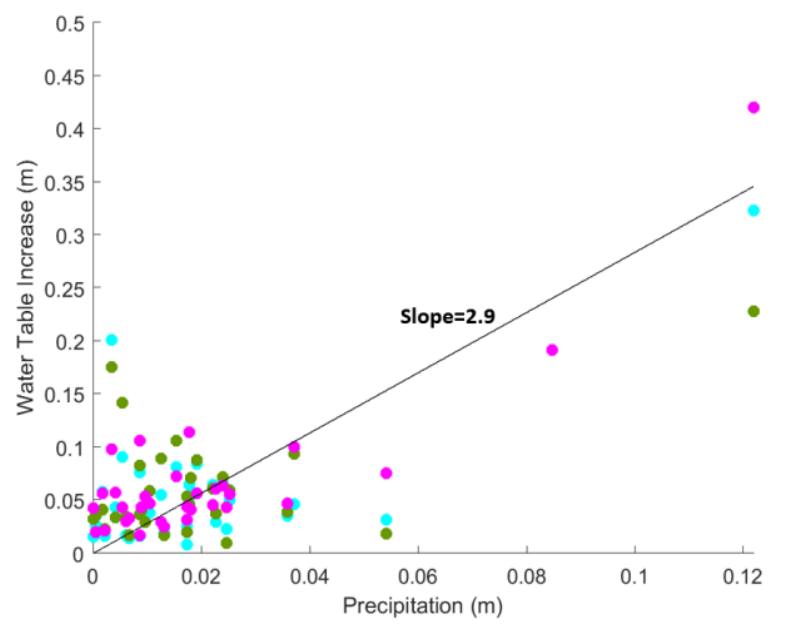

Figure 4.5: Increase in water--table elevation versus total rainfall (squared correlation $\mathrm{R}^{2}=$ 0.70 ) at $\mathrm{x}=310$ (light blue), 400 (green), and $450 \mathrm{~m}$ (pink) (colors match the colors of the wells in Figure 4.1).

\subsection{Flooding on the North Carolina Outer Banks}

\subsection{1 iFlood Citizen Science App}

A citizen-science phone application (app), iFlood, was released in September 2019 to collect flood information, including location, depth, recent rainfall, and photographs on the North Carolina Outer Banks (Figure 4.6). Here, the flood reports are used to validate the combined pulseand-rain flooding model (Equation A7) for the Outer Banks region. When a flood report is submitted, the GPS position of the phone and the position of a drop pin that can be moved manually on the map screen are recorded (Figure 4.6). The user can send a photograph of the flood, answer survey questions about the flood depth, location, and recent rainfall, and provide additional comments, with the data stored on a cloud-based Firebase server. The app was advertised on town social media pages, in local newsletters, and on an NSF repository for citizen science projects, and was presented at an OBX Green Drinks chapter meeting. 


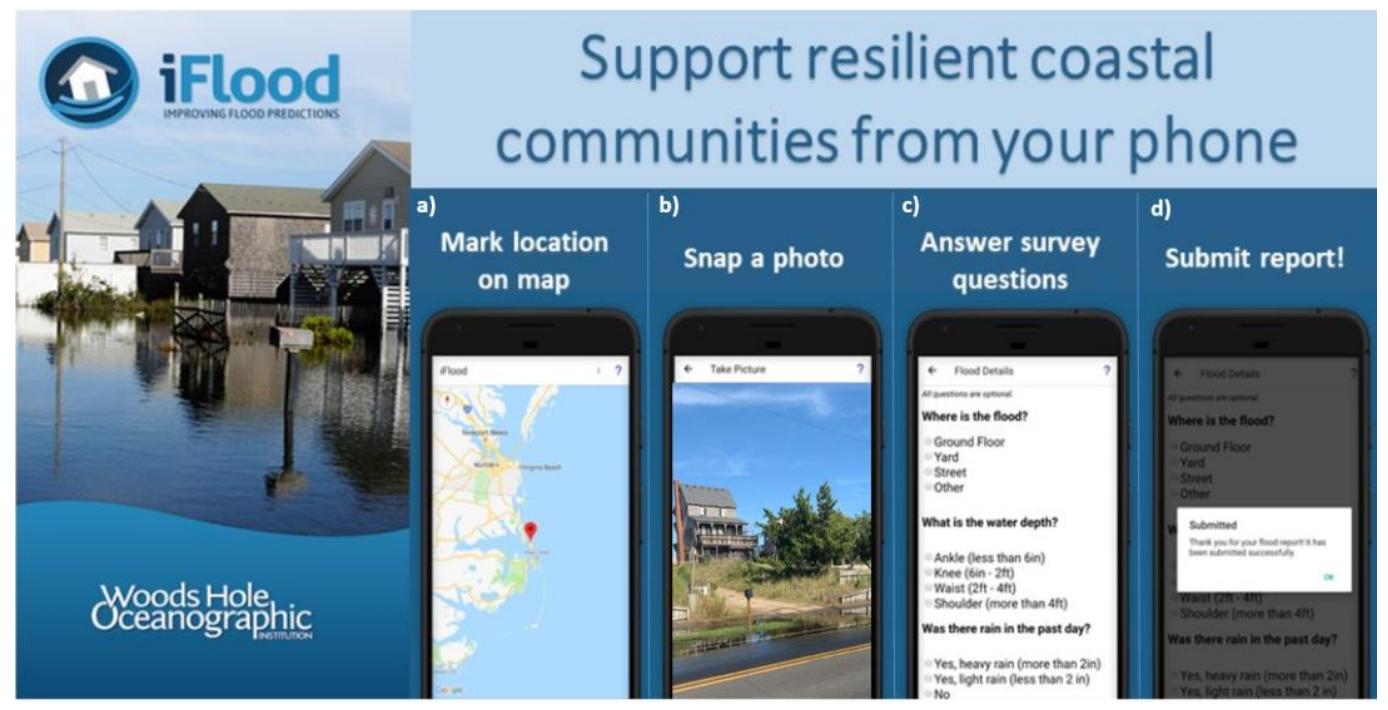

Figure 4.6: Screenshots showing the user interface in the iFlood app. a) map screen b) photo screen c) survey questions screen d) submission screen.

Between September 2019 and February 2020, 34 reports associated with at least 7 storms (including Hurricane Dorian in Sept 2019) indicated flooding on natural (permeable) land surfaces between Corolla and Rodanthe, NC (Figure 4.7). Oceanside flooding occurred up to 5 days after storms with ocean surge up to $1.0 \mathrm{~m}$, significant wave heights in $26-\mathrm{m}$ depth from 3.5 to $7.0 \mathrm{~m}$, and cumulative daily rainfall ranging from negligible to $0.15 \mathrm{~m}$ (Figure 4.8, purple box, dates before December 2019). The most reports (16) associated with a single event occurred following Hurricane Dorian (Figure 4.8). Sound water level changes may have contributed to flooding on the sound side of the barrier island (Figure 4.8, orange box, after December 2019). Owing to a lack of sound water level measurements, the 6 sound-side flood reports are not analyzed. additional flood reports were excluded because the report photo suggested that the flooding resulted primarily from ponding on impermeable surfaces (e.g., roadways). 

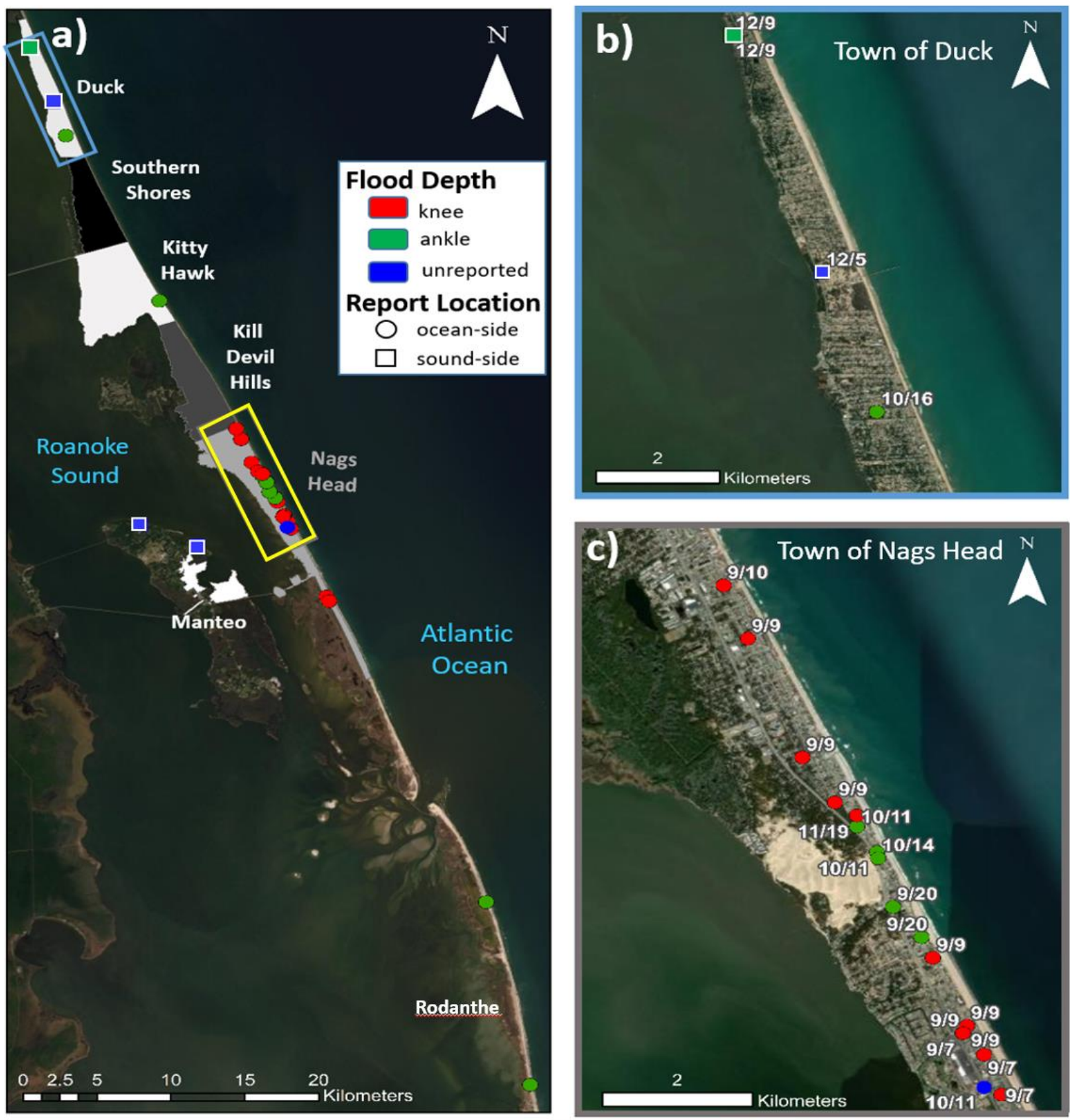

Figure 4.7: a) Map of iFlood app report locations (symbols), and zoomed-in regional maps of reports in b) Duck (extent indicated by blue box in panel a) and c) Nags Head (yellow box in panel a). Marker colors indicate the reported flood depth (knee-high=red, ankle $=$ green, unreported = blue), shape indicates ocean (circle) or sound (square) side of the island, and numbers indicate the date $(\mathrm{MM} / \mathrm{DD})$ the flood was reported. 


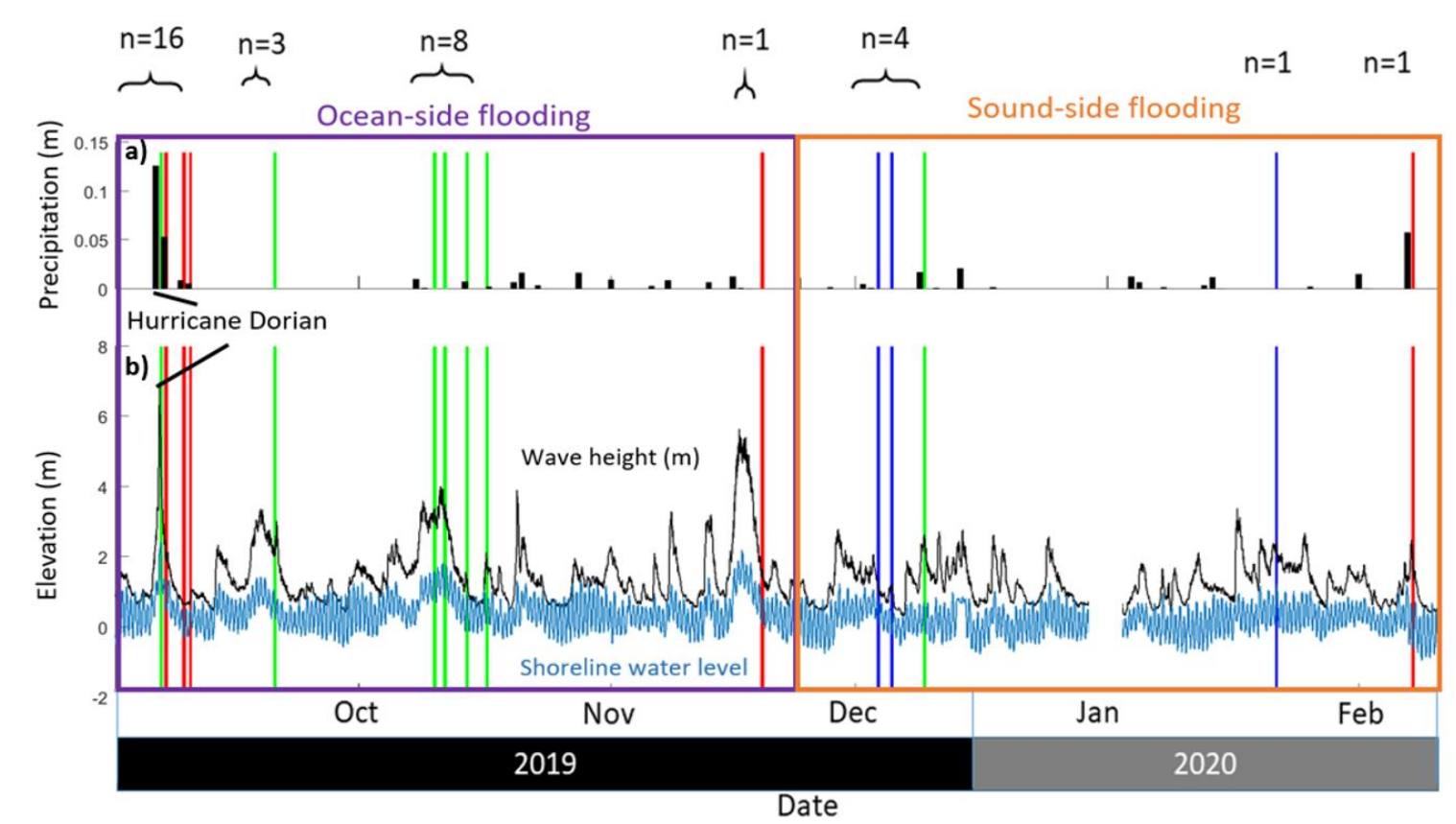

Figure 4.8: a) Precipitation (black bars) and b) offshore significant wave height (black curve) and shoreline water level (blue curve) versus time, with timing of flood reports (indicated by the vertical lines with colors representing reported flood depth (knee-high=red, ankle=green, unreported $=$ blue). The number above the event indicates the number of reports. The purple box (before December 2019) indicates flood reports from the ocean side of the barrier, and the orange box (after December 2019) indicates flood reports from the sound side of the barrier.

\subsubsection{Regional Flood Hindcasts}

The location and timing of the remaining 25 ocean-side flood reports are compared with the analytical estimates of the groundwater-rain-induced flooding (2 examples are shown in Figure 4.9). The analytical model is driven with precipitation measured at the FRF and the approximate ocean shoreline water level estimated as the 36-hr-running-average of the sum of the offshore tide and surge ( $\sim 6 \mathrm{~m}$ depth) and the shoreline setup equal to 0.2 times the offshore (26-m water depth) significant wave height. The cross-shore distance $(x)$ is measured from the estimated dune position, and the land surface elevation is determined from a $5 \times 5 \mathrm{~m}$ digital elevation model (DEM) measured by the Joint Airborne Lidar Bathymetry Technical Center of Expertise (JABLTCX) in 
Fall 2019. At the shoreline (x0) the pre-storm water table is $\sim 0.3 \mathrm{~m}$, based on the estimated overheight generated by the tide (Nielsen 1990; Raubenheimer et al. 1999). Inland of the shoreline the pre-storm water table is estimated using the annual average gradient $(0.0015 \mathrm{~m} / \mathrm{m})$ between the x0 and x160 wells. Based on the aquifer recovery times in the Duck field observations, if a prior storm had occurred within two weeks of the flood report, the water-table level predicted based on the prior storm is used as the height of the pre-storm water table. The diffusivity is assumed to be uniform throughout the surface aquifer (see Discussion).
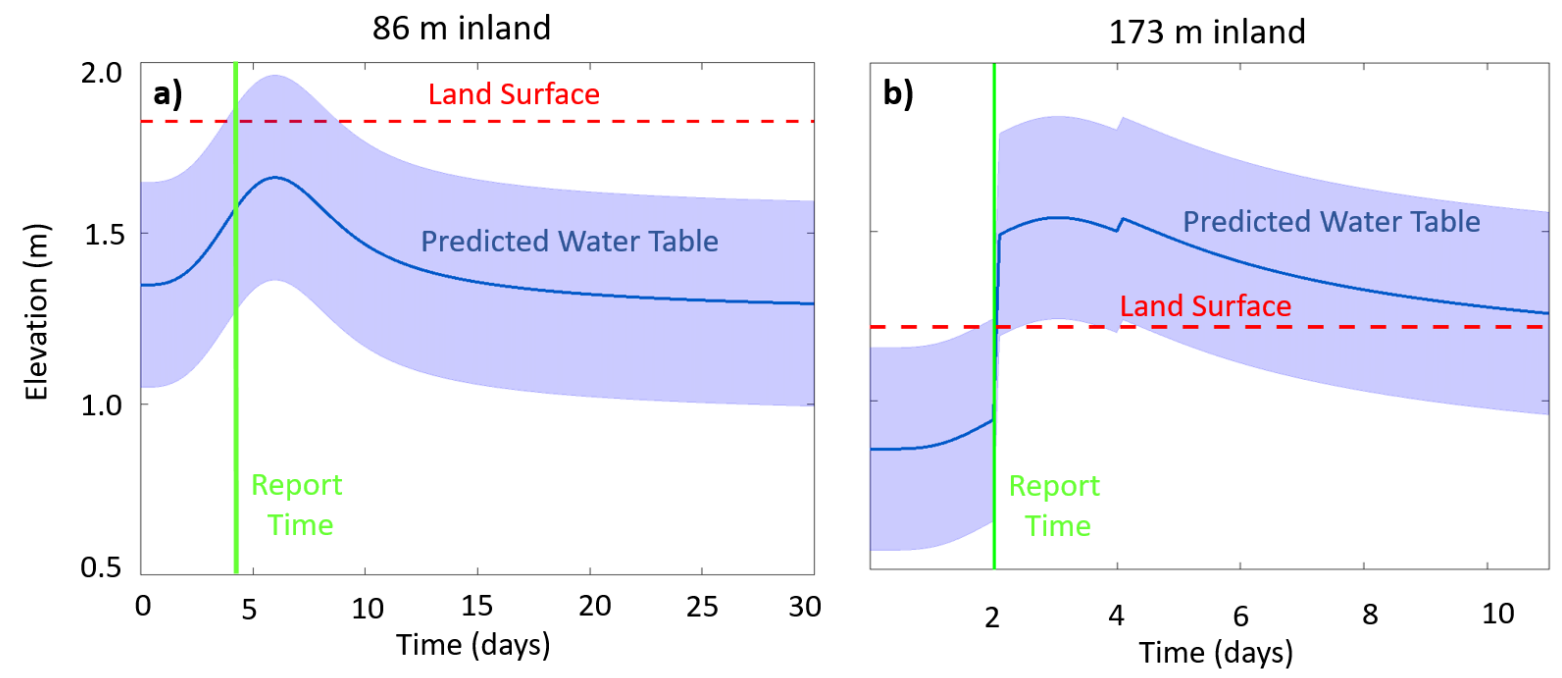

Figure 4.9: Predicted water-table elevation (blue curve, with estimated model uncertainty $(+/-0.3$ m) shown by the blue-shaded region) versus time for an event with a) no rain (ocean surge and setup only) and an event with b) heavy rain at the start of day 2 . The vertical green lines indicate the time a flood report was submitted, and the horizontal red-dashed lines indicate the elevation of the land surface. For both cases, the predicted water-table elevation (within the blue-shaded model uncertainty range) exceeds the land surface at the time the flood report was submitted

The analytical model predicts a flood (the water table exceeds the land surface within the model uncertainty of $+/-0.3 \mathrm{~m})$ that is consistent with the report timing $(+/-1$ day) and location for 19 of the 25 flood reports, for storms with and without precipitation (Figure 4.10). All reports that are not predicted as flooding events by the analytical model were made following storms that 
had precipitation. Surface ponding associated with precipitation that is decoupled from the groundwater behavior (i.e., infiltration limited) may explain this discrepancy.

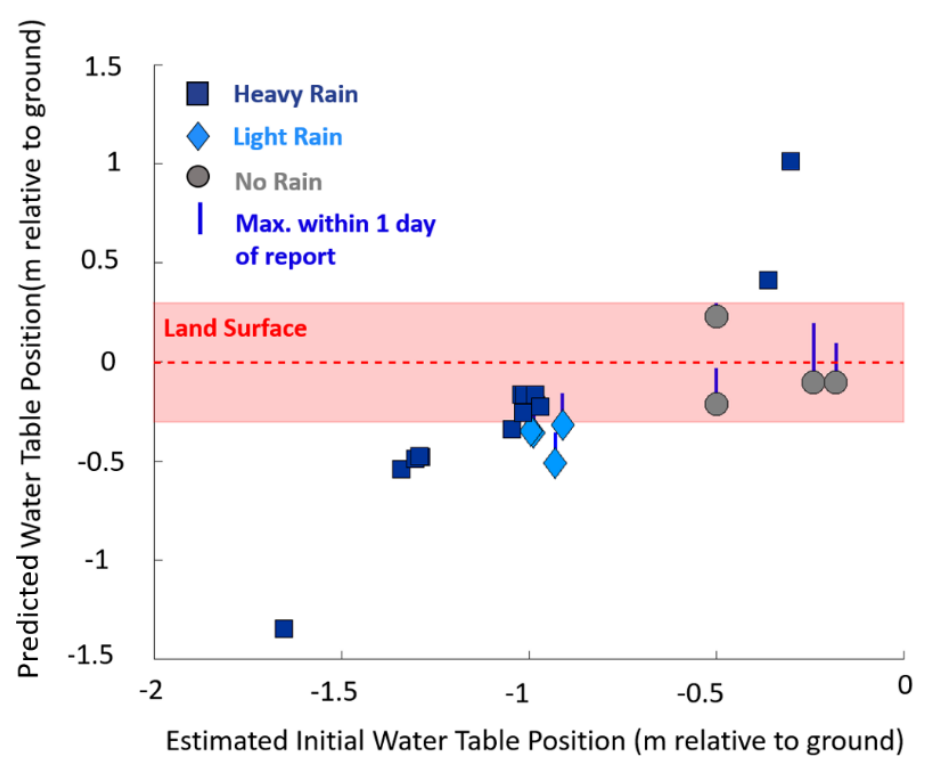

Figure 4.10: Predicted water-table elevation at the report time versus estimated initial water-table elevation relative to the ground surface. Symbol shapes and colors indicate the reported precipitation (dark-blue square $=$ heavy, light-blue diamond $=$ light, gray circle $=$ none). The vertical blue lines indicate the maximum elevation of the water table predicted within one day of the flood report. The dashed red line is the land surface and the shaded pink region is the model uncertainty.

\subsubsection{Regional Flood Vulnerability Forecasts}

The analytical model reproduces the observed maxima in the water table reasonably well, and hindcasts of flooding using the analytical model agree with the timing and location of flood reports received through the iFlood app (Figure 4.10). Thus, the analytical model is used to assess the vulnerability of the Outer Banks to flooding during future storms. Specifically, the analytical model is applied to two hypothetical storms with $\sim 7$ day periods (time coefficient $B=0.3$, equations A1,A2), including a moderate storm with a $0.90 \mathrm{~m}$ increase in the shoreline water level (amplitude $\mathrm{A}=0.90$, Equations $\mathrm{A} 1, \mathrm{~A} 2$ ), and an extreme storm during which the shoreline water level $\mathrm{A}$ 
increased $2.25 \mathrm{~m}$. In both cases, it is assumed that there is no wave overtopping of the dune. The analytical model is applied to every grid cell in the JABLTCX DEM, extending to the lesser of the midpoint of the barrier island or $600 \mathrm{~m}$ inland for each cross-island transect. Beyond $600 \mathrm{~m}$, the fluctuation in the water table associated with the change in the offshore water level is negligible $(<0.1 \mathrm{~m})$. The amount of rainfall needed to flood each grid cell is determined from the effective porosity and the difference between the maximum water-table elevation and the land surface. Flooding is assumed to be constrained to the area within the grid cell, and does not affect adjacent cells 
$2.25 \mathrm{~m}$ increase
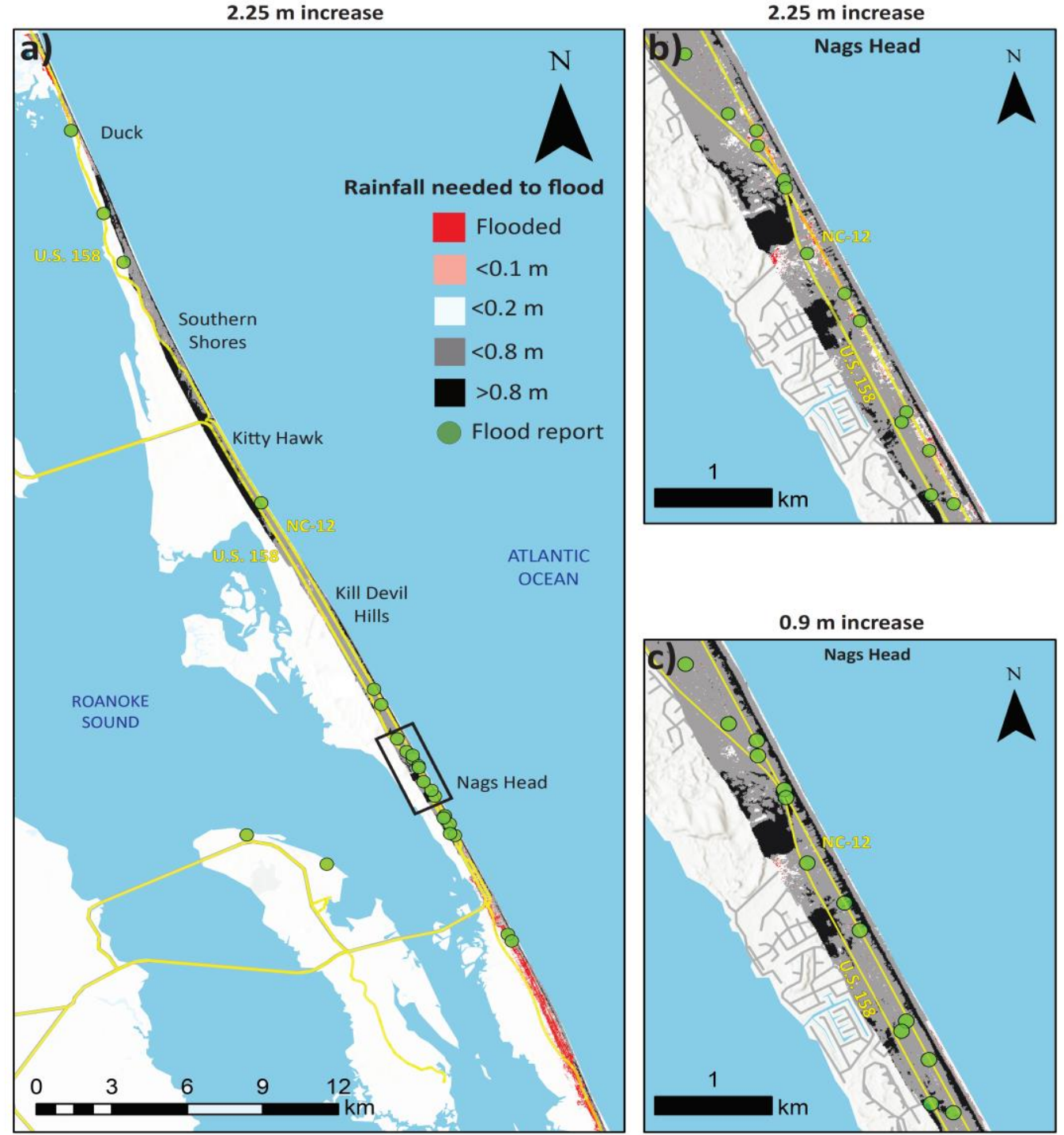

Figure 4.11: Maps of flood vulnerability for the extreme storm case (2.25 $\mathrm{m}$ shoreline waterlevel increase) a) from Northern Duck to Nags Hag and b) close-up of Nags Head region (black box in panel a), and c) flooding in Nags Head for the moderate storm case ( $0.9 \mathrm{~m}$ shoreline water-level increase). 
In the extreme storm case, over $10 \%$ of the land area is flooded owing to the increased shoreline water level and resulting propagation of the groundwater pulse (Figure 4.11a, b). A large band of flooding occurs along the NC-12 highway where the low elevation of the roadway coincides with large increases in the water table owing to the proximity of the shoreline (Figure 4.11b). Flooding of NC-12 has cost more than $\$ 1$ million/year in repairs in Dare County (Woodruff et al. 2018). Inland flooding is patchier and coincides with regions of low ground elevation (Figure 4.11b). For the moderate storm case, $1.6 \%$ of the land area is flooded owing to the groundwater pulse (Figure 4.11c).

The locations of flood reports coincide with areas predicted to have high flood vulnerability for these storm cases (Figure 4.11). Owing to the low land elevation, northern Duck and Rodanthe are predicted to have the highest vulnerability to coastal ground water flooding (Figure 4.11). Most of the barrier would be flooded if precipitation amounts were $\sim 0.8 \mathrm{~m}$ (Figure 4.11, all except black areas). The groundwater pulse amplitude scales linearly with the shoreline fluctuation amplitude (Equation A1), and thus increasing wave height or storm surge increases flooding proportionally. In contrast, the groundwater pulse amplitude scales with the square root of the storm duration (Equation A1), and thus flooding is relatively insensitive to storm period. Doubling the storm duration results in $<1 \%$ change in the flooded area.

\subsection{Discussion}

\subsubsection{Model Assumptions and Limitations}

Errors in the modeled maximum water table partly may be owing to neglecting overland flows during heavy rainfall. The model does not account for surface-subsurface exchange and is 
not valid after the water table exceeds the land surface. Additionally, the model reproduces the maximum water table height more accurately than it reproduces the timing of flooding. Timing errors at least partly are owing to neglecting the asymmetries in the rise and fall of the shoreline water levels. It might be possible to reduce timing errors by including recharge effects in areas with extensive historical monitoring. Timing errors also may result from modeling the rainfall as an instantaneous increase in the water table level, rather than accounting for the time history of rainfall-induced infiltration (Broadbridge \& White, 1988) and of the groundwater drainage (recovery) following the precipitation.

Although the analytical model assumes that the diffusivity of the surface aquifer is spatially uniform, the presence of paleochannels suggests that there is some heterogeneity in the alongshore direction (Browder \& McNinch, 2006; Lazarus \& Murray, 2011; Mallinson et al., 2010), which can introduce errors in the predicted water level. For example, an increase in the hydraulic conductivity or the aquifer depth would increase the maximum water table elevation at a given location because the storm pulse will attenuate less quickly. However, a 50\% change in aquifer diffusivity is expected to cause $<5 \%$ change in the maximum water table elevation. Vertical variation in the location of the confining bed in the cross-shore can influence the cross-shore structure of the water table (Anderson et al., 2000), but these variations are expected to be small relative to the groundwater level changes owing to the storm pulses. Connections between the surface and subsurface confined aquifers also would result in deviations from the storm pulse solution (Trefry \& Bekele, 2004; Trglavcnik et al., 2018). The reasonable agreement between the model and the iFlood reports suggests that aquifer heterogeneity has a relatively small effect on the pulse propagation on the ocean-side of the barrier island. 
Sound-side flooding was not considered in this analysis, owing to the lack of sound water level measurements. Increases in the sound water levels likely produce inland propagating groundwater bulges, similar to those on the ocean side, as well as overtopping shorelines and inundating low-lying sound-side neighborhoods. However, changes in the sound water level are better approximated as a step-function (rapid increase with a slow decline) than a Gaussian (Caldwell, 2001). In areas where the island width is narrower than the damping distance of the pulse, the sound-driven pulse may interact with the ocean-driven pulse to create more complex fluctuations in the water table, similar to interactions between tidal fluctuations that have been observed across narrow barriers (Colyar, 2016; Huang et al., 2015; Li et al., 2000). As a result, it may be possible to develop an analytical model for flooding across the entire barrier island that incorporates sound and ocean water level fluctuations, as well as rainfall.

\subsubsection{Future Management of Groundwater-Flooding on the Outer Banks}

The results suggest that the storm-driven groundwater pulse could flood more than $10 \%$ of the ocean-side of the Outer Banks during an event with a $2.25 \mathrm{~m}$ increase in shoreline water level (e.g., $1.00 \mathrm{~m}$ storm surge and $6.25 \mathrm{~m}$ waves) without precipitation (Figure 11). This estimate is conservative because the initial water-table distribution was designed to represent the aquifer under calm conditions. The extent of flooding across the barrier would be more severe if the water table had not recovered from a prior storm or rainfall. Additionally, groundwater-driven flooding is likely to increase as the water table increases with rising sea levels (Bjerklie et al. ,2012). Global sea level is predicted to rise between $0.5-1.4 \mathrm{~m}$ by 2100 , and sea level rise along the Atlantic Coast is predicted to outpace the global estimate (Sweet et al., 2020). Consequently, owing to sea level 
rise and the increasing intensity and duration of North Atlantic storms (Knutson et al., 2020; Patricola \& Wehner, 2018), coastal groundwater-driven flooding is expected to present a persistent coastal management challenge.

Structural protections, such as seawalls, jetties, and dikes have been the preferred approach to coastal flood prevention (Dugan et al., 2008; Gittman et al., 2015). Although these protections are effective at mitigating surface water inundation driven by surge, waves, and tides, they do not impede flooding driven by groundwater (Rotzoll \& Fletcher, 2013). Additionally, the presence of hardened structures can block the groundwater discharging to the ocean, prolonging the post-storm recovery of the water table (Lee et al., 2019). Flood recovery time is important for assessing the duration of impairment of infrastructure and the vulnerability to future flooding (Abboud et al., 2018; Chisolm \& Matthews, 2012; Lu et al., 2015) and should be addressed in future studies.

By understanding the processes contributing to flooding, coastal managers can assess the effectiveness of different flood mitigation strategies. In the town of Nags Head, the iFlood project has reinforced the importance of groundwater levels for flood management. Groundwater flooding is an emerging issue the town has focused on in recent years, and several groundwater-surfacewater management projects are being implemented to reduce the frequency and extent of flooding in the town, including a groundwater pumping system used to reduce the water table level in advance of major storms.

Offshore wave heights and precipitation amounts that drive the analytical model are among the most ubiquitous measurements collected in global coastal observational arrays. Consequently, it may be feasible to adapt this framework to study regional groundwater-driven flooding in other low-lying coastal environments where the aquifer properties are roughly uniform. 


\subsubsection{Use of Phone Apps for Research and Increasing Community Awareness}

iFlood reports extended the scope of the study from a single site, to a $70 \mathrm{~km}$ stretch of the Outer Banks between Duck and Rodanthe, NC. Although survey responses and photos are used to exclude cases with surface ponding on impermeable surfaces, in some cases the ground surface is difficult to determine. In addition, the phone GPS did not always update automatically, and it sometimes was necessary to use the photo to refine the report location. However, the flooding reports and photos provided by the application users enabled evaluation of the model for a large region of the Outer Banks.

Additionally, the citizen-science app increased community awareness of coastal flooding issues and helped town managers identify regions in their communities where there are recurrent flooding issues. The app also enables citizens of the Outer Banks to understand the risks associated with living in a flood-vulnerable environment and to actively engage with a persistent issue in their communities. Approximately 70 residents attended a public presentation regarding groundwaterinduced flooding and the app, which has been installed over 100 times by users presumed to be local residents. Similar citizen-science approaches could be applied to address other issues related to coastal flooding, and the town of Nags Head plans to use iFlood as a reference to expand on the methods the town uses to engage its citizenry and bring awareness to emerging issues.

\subsection{Conclusions}

Three years of groundwater level measurements spanning the 550-m-wide barrier island near Duck, NC were used to develop an analytical model to predict the response of the water table to surge, wave setup, and precipitation during coastal storms. The groundwater elevation near the 
ocean increased more than $1 \mathrm{~m}$ during storms, resulting in inland-directed head gradients. The bulge of groundwater moved inland causing up to a $0.5 \mathrm{~m}$ increase in groundwater levels $310 \mathrm{~m}$ inland from the dune. A linear, analytical theory (Li et al. 2004) for the propagation of storm pulses in shallow aquifers reproduces the amplitude attenuation and phase change observed across the island for 26 storm events with minimal rainfall. Errors in the modeled maximum water table are less than $0.1 \mathrm{~m}$ from the dune to $160 \mathrm{~m}$ inland. Infiltration of precipitation results in approximately a threefold increase in the groundwater level relative to the amount of rainfall.

Citizen-science reports of flooding along 70-km of the Outer Banks of North Carolina submitted with a smartphone app, iFlood, were used to validate the analytical model. Between Sept 2019 and Feb 2020, 25 reports on the ocean-side of the island associated with 7 storms showed flooding on natural (permeable) land surfaces between Corolla and Rodanthe, NC. Flooding occurred after storms with large ocean surge and waves, with and without significant rainfall. The analytical model predicted a flooding event that was consistent with the timing and location for 19 of these reports.

The analytical model provides a simple and computationally efficient framework for predicting flooding risk along the ocean-side of the barrier island. For a hypothetical storm with a $2.25 \mathrm{~m}$ increase in shoreline water level, the analytical model suggests that more than $10 \%$ of the ocean-side of the Outer Banks could be inundated by coastal-groundwater flooding in the absence of rainfall (precipitation would increase the flooding extent).

\subsection{Acknowledgements}

We thank the USACE CHL-Field Research Facility for ocean and meteorological observations, Levi Gorrell, Fred Marin, Emmett Krupczak, Heidi Wadman, Jesse McNinch, and Pat Dickhudt 
for assistance deploying and maintaining the groundwater wells, and Kent Hathaway for assistance with precipitation data. We also thank the users of the iFlood app who contributed flood reports to this project. Funding was provided by the U.S. Coastal Research Program, the National Science

Foundation, a National Science Foundation Graduate Research Fellowship, the Woods Hole Oceanographic ISP program, and a Vannevar Bush Faculty Fellowship.

\subsection{References}

Abarca, E., Karam, H., Hemond, H., \& Harvey, C. (2013). Transient groundwater dynamics in a coastal aquifer: The effects of tides, the lunar cycle, and the beach profile. Water Resources Research, 49(5), 2473-2488. https://doi.org/10.1002/wrcr.20075

Abboud, J.M., Ryan, M.C., \& Osborn, G.D. (2018). Groundwater flooding in a river-connected alluvial aquifer. Journal of Flood Risk Management. 11, e12334. https://doi.org/10.1111/jfr3.12334

Anderson, W.P., Evans, D.G.,\& Snyder, S.W. (2000). The effects of Holocene barrier-island evolution on water-table elevations, Hatteras Island, North Carolina, USA. Hydrogeology Journal, 8, 390-404. https://doi.org/10.1007/s100400000081

Anderson, W. P. J., \& Lauer, R. M. (2008). The role of overwash in the evolution of mixing zone morphology within barrier islands. Hydrogeology Journal, 16(8), 1483-1495.

https://doi.org/10.1007/s10040-008-0340-z

Befus, K.M., Barnard, P.L., Hoover, D.J., Finzi Hart, J.A. \& Voss, C.I. (2020). Increasing threat of coastal groundwater hazards from sea-level rise in California. Nature Climate Change, 10, 946-952. https://doi.org/10.1038/s41558-020-0874-1

Bevacqua, E., Maraun, D., Vousdoukas, M. I., Voukouvalas, E., Vrac, M., Mentaschi, L., \& Widmann, M. (2019). Higher probability of compound flooding from precipitation and storm surge in Europe under anthropogenic climate change. Science Adavances:

Climatology, 5.

Bjerklie, D.M., Mullaney, J.R., Stone, J.R., Skinner, B.J., Ramlow, M.A., 2012. Preliminary investigation of the effects of sea-level rise on groundwater levels in New Haven, Connecticut. U.S. Geologic Survey. 
Boss, S. K., Hoffman, C. W., \& Cooper, B. (2002). Influence of fluvial processes on the quaternary geologic framework of the continental shelf, North Carolina, USA. Marine Geology, 183(1-4), 45-65. https://doi.org/10.1016/S0025-3227(01)00253-5

Bouwer, H., \& Rice, R. C. (1976). A slug test for determining hydraulic conductivity of unconfined aquifers with completely or partially penetrating wells. Water Resources Research, 12(3), 423-428. https://doi.org/10.1029/WR012i003p00423

Broadbridge, P. \& White, I. (1988). Constant rate rainfall infiltration: A versatile nonlinear model: 1. Analytic solution. Water Resouces Research. 24, 145-154. https://doi.org/10.1029/WR024i001p00145

Browder, A. G., \& McNinch, J. E. (2006). Linking framework geology and nearshore morphology: Correlation of paleo-channels with shore-oblique sandbars and gravel outcrops. Marine Geology, 231(1-4), 141-162. https://doi.org/10.1016/j.margeo.2006.06.006

Brown, D. L., Narasimhan, T. N., \& Demir, Z. (1995). An evaluation of the Bouwer and Rice method of slug test analysis. Water Resources Research, 31(5), 1239-1246. https://doi.org/10.1029/94WR03292

Butler, J. J., McElwee, C. D., \& Liu, W. (1996). Improving the quality of parameter estimates obtained from slug tests. Ground Water, 34(3), 480-490. https://doi.org/10.1111/j.17456584.1996.tb02029.x

Caldwell, W. (2001). Hydrologic and salinity characteristics of Currituck Sound and selected tributaries in North Carolina and Virginia, 1998-99. USGS, Raleigh NC.

Cartwright, N., Li, L., \& Nielsen, P. (2004). Response of the salt-freshwater interface in a coastal aquifer to a wave-induced groundwater pulse: field observations and modelling. Advances in Water Resources, 27(3), 297-303. https://doi.org/10.1016/j.advwatres.2003.12.005

Cartwright, N., \& Gibbes, B. (2011). Oceanic pulse forcing of a beach groundwater system. In Coasts and Ports 2011: Diverse and Developing: Proceedings of the 20th Australasian Coastal and Ocean Engineering Conference and the 13th Australasian Port and Harbour Conference (p. 140). Engineers Australia.

Chisolm, E. I., \& Matthews, J. C. (2012). Impact of Hurricanes and Flooding on Buried Infrastructure. Leadership and Management in Engineering, 12(3), 151-156. https://doi.org/10.1061/(ASCE)LM.1943-5630.0000182 
Cobby, D., Morris, S., Parkes, A., \& Robinson, V. (2009). Groundwater flood risk management: advances towards meeting the requirements of the EU floods directive. Journal of Flood Risk Management, 2(2), 111-119. https://doi.org/10.1111/j.1753-318X.2009.01025.x

Colyar, M. A. (2016). The influence of tides, waves, and overtopping on the near-shore water table. UC Irvine. ProQuest ID: Colyar_uci_0030M_14174. Merritt ID: ark:/13030/m5km40sp.

Crosbie, R. S., Binning, P., \& Kalma, J. D. (2005). A time series approach to inferring groundwater recharge using the water table fluctuation method. Water Resources Research, 41(1), 1-9. https://doi.org/10.1029/2004WR003077

Dugan, J. E., Hubbard, D. M., Rodil, I. F., Revell, D. L., \& Schroeter, S. (2008). Ecological effects of coastal armoring on sandy beaches. Marine Ecology, 29(s1), 160-170. https://doi.org/10.1111/j.1439-0485.2008.00231.x

Elko, N., Dietrich, C., Cialone, M. A., Stockdon, H., Bilskie, M. W., Boyd, B., et al. (2019). Advancing the understanding of storm processes and impacts. Shore \& Beach.

Elko, N. A., Sallenger, A. H., Guy, K., Stockdon, H. F., \& Morgan, K. L. M. (2002). Barrier Island Elevations Relevant to Potential Storm Impacts: 1. Techniques. US Geological Survey Open File Report, 02-287.

Elko, N., Feddersen, F., Foster, D., Hapke, C., Mcninch, J., Mulligan, R., et al. (2015). The future of nearshore processes research The Nearshore Processes Community. Shore \& Beach $\square$ (Vol. 83).

FEMA (2018) Hydrologic analysis of Hurricane Matthew's impact on dam safety in North Carolina and South Carolina.

Fofonoff, N., \& Millard, R.C. Jr. (1983). Algorithms for the computation of fundamental properties of seawater. Paris, France, UNESCO, 53pp. (UNESCO Technical Papers in Marine Sciences; 44), http://hdl.handle.net/11329/109

Gittman, R. K., Fodrie, F. J., Popowich, A. M., Keller, D. A., Bruno, J. F., Currin, C. A., et al. (2015). Engineering away our natural defenses: an analysis of shoreline hardening in the US. Frontiers in Ecology and the Environment, 13(6), 301-307. https://doi.org/10.1890/150065 
Glover, R. E. (1959). The pattern of fresh-water flow in a coastal aquifer. Journal of Geophysical

Research, 64(4), 457-459. https://doi.org/10.1029/jz064i004p00457

Guza, R. T., \& Thornton, E. B. (1981). Wave set-up on a natural beach. Journal of Geophysical Research, 86(C5), 4133. https://doi.org/10.1029/JC086iC05p04133

Horn. D \& Webel, B. (2019). Introduction to the National Flood Insurance Program (NFIP). Congressional Research Service. R44593, https://fas.org/sgp/crs/homesec/R44593.pdf

Huang, F. K., Chuang, M. H., Wang, G. S., \& Yeh, H. Der. (2015). Tide-induced groundwater level fluctuation in a U-shaped coastal aquifer. Journal of Hydrology, 530, 291-305. https://doi.org/10.1016/j.jhydrol.2015.09.032

Hvorslev, \& J., M. (1951). Time Lag and Soil Permeability in Ground-Water Observations, Waterways Experiment Station, Corps of Engineers. U. S. Army, Bulletin, 36, 49.

Knutson, T., Camargo, S. J., Chan, J. C. L., Emanuel, K., Ho, C. H., Kossin, J., et al. (2020). Tropical cyclones and climate change assessment part II: Projected response to anthropogenic warming. Bulletin of the American Meteorological Society, 101(3), E303E322. https://doi.org/10.1175/BAMS-D-18-0194.1

Lautier, J. C. (2009). Hydrogeologic Framework and Ground Water Conditions in the North Carolina East Central Coastal Plain.

Lazarus, E. D., \& Murray, A. B. (2011). An integrated hypothesis for regional patterns of shoreline change along the Northern North Carolina Outer Banks, USA. Marine Geology, 281(1-4), 85-90. https://doi.org/10.1016/j.margeo.2011.02.002

Lee, W.D., Yoo, Y.J., Jeong, Y.M., \& Hur, D.S. (2019). Experimental and numerical analysis on hydraulic characteristics of coastal aquifers with Seawall. Water, 11(11), 2343. https://doi.org/10.3390/w11112343

Li, L., Barry, D. A., Cunningham, C., Stagnitti, F., \& Parlange, J. Y. (2000). A two-dimensional analytical solution of groundwater responses to tidal loading in an estuary and ocean. Advances in Water Resources, 23(8), 825-833. https://doi.org/10.1016/S03091708(00)00016-6 
Li, L., Cartwright, N., \& Nielsen, P. (2004). Response of the salt-freshwater interface in a coastal aquifer to a wave-induced groundwater pulse: field observations and modelling. Advances in Water Resources.

Longuet-Higgins, M. S., \& Stewart, R. W. (1964). Radiation stresses in water waves; a physical discussion, with applications. Deep-Sea Research, 11, 529-562.

Lu, Q. C., Peng, Z. R., \& Zhang, J. (2015). Identification and prioritization of critical transportation infrastructure: Case study of coastal flooding. Journal of Transportation Engineering, 141(3). https://doi.org/10.1061/(ASCE)TE.1943-5436.0000743

MacDonald, D. M. J., Bloomfield, J. P., Hughes, A. G., MacDonald, A. M., Adams, B., \& McKenzie, A. A. (n.d.). Improving the understanding of the risk from groundwater flooding in the $U K$.

Mallinson, D.J., Smith, C.W., Culver, S.J., Riggs, S.R. \& Ames, D (2010). Geological characteristics and spatial distribution of paleo-inlet channels beneath the outer banks barrier islands, North Carolina, USA. Estuarine, Coastal and Shelf Science, 88(2), 175189.

Manahan, S., Martin, W. K., \& Guo, W. (1998). Dare County-wide Hydrogeological Study and Groundwater Resource Evaluation. Dare County Water Production Department, Kill Devil Hills, NC.

Meinzer, O. (1923). The occurrence of ground water in the United States with a discussion of principles.

Meisburger, E. P., Williams, S. J., \& Judge, C. (1989). Physiographic and Geological Setting of the Coastal Engineering Research Center's Field Research Facility. Vicksburg, MS.

Moftakhari, H. R., AghaKouchak, A., Sanders, B. F., Feldman, D. L., Sweet, W., Matthew, R. A., \& Luke, A. (2015). Increased nuisance flooding along the coasts of the United States due to sea level rise: Past and future. Geophysical Research Letters, 42(22), 9846-9852. https://doi.org/10.1002/2015GL066072

Morris, S. E., Cobby, D., \& Parkes, A. (2007). Towards groundwater flood risk mapping. Quarterly Journal of Engineering Geology and Hydrogeology, 40(3), 203-211.

Mulligan, R. P., Walsh, J. P., \& Wadman, H. M. (2014). Storm surge and surface waves in a shallow lagoonal estuary during the crossing of a hurricane. Journal of Waterway, Port, Coastal, and Ocean Engineering, 141(4), A5014001. https://doi.org/10.1061/(ASCE)WW.1943-5460.0000260 
Nielsen, P. (1988). Wave setup: A field study. Journal of Geophysical Research, 93(C12), 15643. https://doi.org/10.1029/JC093iC12p15643

Nielsen, P. (1990). Tidal dynamics of the water table in beaches. Water Resources Research, 26(9), 2127-2134. https://doi.org/10.1029/WR026i009p02127

Nielsen, P., Aseervatham, R., Fenton, J. D., \& Perrochet, P. (1997). Groundwater waves in aquifers of intermediate depths. Advances in Water Resources, 20.

Patricola, C. M., \& Wehner, M. F. (2018). Anthropogenic influences on major tropical cyclone events. Nature, 563, 339-346.

Raubenheimer, B., Guza, R.T. \& Elgar, S. (1999). Tidal water table fluctuations in a sandy ocean beach. Water Resources Research. 35(8), 2313-2320.

Raubenheimer, B., Guza, R.T. \& Elgar, S. (2001). Field observations of wave-driven setdown and setup. Journal of Geophysical Research: Oceans. 106, 4629-4638.

https://doi.org/10.1029/2000JC000572

Riggs, S. R., Cleary, W. J., \& Snyder, S. W. (1995). Influence of inherited geologic framework on barrier shoreface morphology and dynamics. Marine Geology, 126(1-4), 213-234. https://doi.org/10.1016/0025-3227(95)00079-E

Rotzoll, K., \& El-Kadi, A. I. (2008). Estimating hydraulic properties of coastal aquifers using wave setup. Journal of Hydrology, 353(1), 201-213.

https://doi.org/10.1016/j.jhydrol.2008.02.005

Rotzoll, K., \& Fletcher, C. H. (2013). Assessment of groundwater inundation as a consequence of sea-level rise. Nature Climate Change, 3(5), 477-481. https://doi.org/10.1038/nclimate1725

Smail, R. A., Pruitt, A. H., Mitchell, P. D., \& Colquhoun, J. B. (2019). Cumulative deviation from moving mean precipitation as a proxy for groundwater level variation in Wisconsin. Journal of Hydrology X, 5, 100045. https://doi.org/10.1016/j.hydroa.2019.100045

Sweet, W., Dusek, G., Carbin, G., Marra, J., Marcy, D., \& Simon, S. (2020). NOAA Technical Report NOS CO-OPS 092 noaa National Oceanic and Atmospheric Administration 2019 State of U.S. High Tide Flooding with a 2020 Outlook. 
Trefry, M.G. \& Bekele, E. (2004). Structural characterization of an island aquifer via tidal methods. Water Resources Research. 40(1). https://doi.org/10.1029/2003WR002003

Trglavcnik, V., Morrow, D., Weber, K. P., Li, L., \& Robinson, C. E. (2018. Analysis of tide and offshore storm-induced water table fluctuations for structural characterization of a coastal island aquifer. Water Resources Research, 54(4), 2749-2767. https://doi.org/10.1002/2017WR020975

Vitousek, S., Barnard, P. L., Fletcher, C. H., Frazer, N., Erikson, L., \& Storlazzi, C. D. (2017). Doubling of coastal flooding frequency within decades due to sea-level rise. Scientific Reports, 7(1), 1-9. https://doi.org/10.1038/s41598-017-01362-7

Wahl, T., Jain, S., Bender, J., Meyers, S. D., \& Luther, M. E. (2015). Increasing risk of compound flooding from storm surge and rainfall for major US cities. Nature Climate Change, 5(12), 1093-1097. https://doi.org/10.1038/nclimate2736

Winner, M. D. J., \& Coble, R. (1996). Hydrogeologic framework of the North Carolina Coastal Plain.

Woodruff, J. D., Irish, J. L., \& Camargo, S. J. (2013). Coastal flooding by tropical cyclones and sea-level rise. Nature, 504(7478), 44-52.

Woodruff, S., BenDor, T. K., \& Strong, A. L. (2018). Fighting the inevitable: infrastructure investment and coastal community adaptation to sea level rise. System Dynamics Review, 34(1-2), 48-77. https://doi.org/10.1002/sdr.1597

Zhang, K. \& Leatherman, S. (2011). Barrier island population along the U.S. Atlantic and Gulf coasts. Journal of Coastal Research. 272, 356-363. https://doi.org/10.2112/JCOASTRESD-10-00126.1

Zhang, M., Singh, H.V., Migliaccio, K.W. \& Kisekka, I. (2017). Evaluating water table response to rainfall events in a shallow aquifer and canal system. Hydrological Processes. 31, 3907-3919. https://doi.org/10.1002/hyp.11306 


\section{Chapter 5: Conclusions and Future Work}

\subsection{Conclusions}

Three years of groundwater measurements (pressure, temperature, and salinity) spanning the 550-m-wide barrier island near Duck, NC are used jointly with oceanographic (waves, tides, temperature), sound (water level), meteorological (precipitation, air temperature), and morphological (dune profiles and beach surveys) observations collected at the U.S. Army Corps of Engineers Field Research Facility to characterize the dynamics of a barrier island aquifer. Interactions between the ocean, the sound, and the coastal aquifer drive the observed temporal and spatial patterns in groundwater head, temperature and salinity and analytical theories can be applied to describe the propagation of storm-and-tide-driven head fluctuations and the evolution of the cross-island water table. In particular:

- The groundwater elevation near the ocean increased more than $1 \mathrm{~m}$ during storms, resulting in inland-directed head gradients. After the storm, the bulge of groundwater moved inland causing up to a $0.5 \mathrm{~m}$ increase in groundwater levels $310 \mathrm{~m}$ inland from the dune.

- Following storms, salinity and temperature act as a tracer of the ocean water that infiltrates into the aquifer (upper saline plume, USP). Plumes of high salinity (> 20 PSU) were measured under the ocean dune at $\sim 3 \mathrm{~m}$ depth during and following 9 storms. The plume temperatures are similar to ocean water temperatures, which are relatively warm (cold) with respect to the groundwater during the fall (spring). Beach topography changed significantly during the study, affecting the location of ocean wave runup, and possibly altering the USP structure and inland penetration. 
- Heat exchanges between the aquifer, sound, and ocean control the spatial pattern of seasonal temperature fluctuations in the aquifer. On the ocean side of the island seasonal temperature fluctuations have a smaller range than near the sound, (roughly 4C and 10C for the ocean and sound respectively). The seasonal temperature fluctuations on the ocean side of the island also have a longer lag relative to the change in air temperature than those on the sound side (roughly 0.5 months and 3 months for the ocean and sound respectively).

- The logarithm of the amplitude attenuation and the phase lag evolution for semidiurnal-, diurnal-, and storm-driven fluctuations vary linearly with inland distance at rates increasing with fluctuation frequency (e.g., tides attenuate more rapidly than the longer-duration storm fluctuations), as expected for the approximately homogeneous aquifer.

- Differences between the tidal amplitude attenuation and phase lag rates are consistent with small amplitude, intermediate depth aquifer theory. Tidal fluctuations near the surface of the aquifer lag those near the bottom, as expected in an intermediate depth aquifer. Numerical simulations with MODFLOW-NWT reproduced the observed inland and vertical tidal propagation for a constant depth, homogeneous, isotropic surface aquifer without a capillary fringe.

- The propagation of longer-period (lower frequency) storm-induced increases in ocean water levels is consistent with small amplitude, shallow aquifer (linear) theory.

- An analytical water-table evolution model driven with estimated ocean shoreline water levels (based on the 36-hr-averaged offshore tide, surge, and wave height) and 
measured precipitation predicts the maximum water-table height within $0.1 \mathrm{~m}$ of the observed levels across the barrier island.

- Applying the water table evolution model to predict regions of groundwater flood vulnerability across a 50-km section of the North Carolina Outer Banks during a storm with a $2.25 \mathrm{~m}$ increase in the offshore water level, suggests that $\sim 10 \%$ of the land area on the ocean side of the island could be flooded by groundwater (without overtopping or precipitation).

This thesis has demonstrated the insights that can be gained from integrating oceanographic, meteorological, morphological and hydrogeological measurements to evaluate groundwater dynamics. Additionally, this thesis demonstrates the benefits of maintaining long-term observational arrays in coastal systems. The results will help support the management of groundwater resources and flooding hazards in sandy barrier island systems. Groundwater dynamics will become increasingly important for coastal management in the face of climate change. Sea-level rise will elevate the coastal water table, and both ocean windstorms and rain storms are predicted to increase in intensity and duration (Befus et al. 2020; Jalowska et al. 2021;

Patricola \& Wehner, 2018; Rotzoll et al. 2013). Therefore, using long-term system-wide approaches to characterize aquifer dynamics in response to multi-hazard events will continue to be beneficial.

\subsection{Future Work}

Results from Chapter 2 showed that the USP can penetrate inland of the dune following storms and may persist for several months, which has important implications for mixing and 
salinization in the aquifer. Simulations of the USP have suggested that it is the deeper tail of the intertidal USP that migrates inland (Boufadel et al., 2011), but the observations do not measure how the shape of the plume evolves over time. Additionally, there are differences in the timing, duration, and magnitude of the plume observed behind the dune at the northern and southern transect locations that are hypothesized to arise from differences in beach topography. Numerical simulations of the storm-driven groundwater response could provide insight into the plume geometry under different morphological conditions, but are challenging to implement in groundwater models because of the large area and high rate of inundation during these events (simulation of wetting/drying processes can cause model convergence issues and is

computationally intensive).

Results from Chapter 1 showed that beach morphology may affect the groundwater, but the groundwater behavior also may affect the beach morphology. Gradients in the sediment transported by wave run-up and run-down results in erosion and accretion in the swash zone. As a wave runs up the beach, water may infiltrate into the underlying aquifer creating a flow asymmetry between the uprush and backwash that may facilitate onshore sediment transport (Duncan, 1964; Turner, 1995; Quick, 1991). The magnitude of the infiltration loss between the uprush and backwash depends on the position of the groundwater table. Therefore, lowering the water table is expected to enhance onshore sediment transport and coastal managers have extracted water from nearshore aquifers to promote beach rebuilding (Turner \& Leatherman, 1997). Swash zone infiltration/exfiltration also can alter the effective weight of the sediment and modify the shape of the boundary layer, which have competing effects on sediment transport (Turner \& Masselink, 
1998). Infiltration increases the effective weight of a sediment particle, stabilizing the bed. Infiltration also compresses the boundary layer, enhancing the bed shear stress. Conversely, exfiltration reduces the effective weight of a sediment particle and expands the boundary layer, reducing the bed shear stress. Analytical models have been developed to account for the impact of infiltration/exfiltration on sediment transport (Turner \& Masselink, 1998; Butt et al. 2001). For these studies, modified sediment transport rates were only calculated for a single location, so the effect of infiltration/exfiltration on the full beach evolution has not been characterized. Additionally, the importance of feedbacks between the runup (the mean and fluctuating wavedriven shoreline movement), sediment transport, and background groundwater processes to the beach response during and following storms is unknown and could be addressed in future work.

During the observation period, no storm generated large enough water levels to inundate the dune and analysis conducted in all 3 chapters assumes that there is no wave overtopping of the dune. However, since dune heights vary across the Outer Banks and the duration and intensity of ocean windstorms is hypothesized to increase, wave overtopping is an important mechanism driving flooding and aquifer salinization (Patricola \& Wehner, 2018). Overtopping introduces a layer of saltwater on top of the fresher inland groundwater and the resulting density instabilities generate lobes of salt water that penetrate into the fresher groundwater (also referred to as density fingering) that significantly alter groundwater flow patterns (Wilson et al. 2011; Yang et al. 2013). To address wave overtopping, a numerical modeling approach that couples surface and subsurface processes is needed. Developing coupled-surface and subsurface models for barrier island systems 
also would improve analysis of flood recovery time, which is not included in the analytical approaches applied in this thesis.

Hindcasts of groundwater flooding presented in Chapter 3 demonstrated that the analytical water table evolution model driven by measured ocean properties and precipitation has skill in predicting the timing and location of groundwater flooding. By coupling the groundwater flooding model with real-time forecasts of wave and water levels generated from coastal models (e.g.

Delft3D, COAWST, ROMS) it may be possible to forecast the locations of groundwater-driven flooding. Town officials in both Duck and Nags Head have emphasized that flood forecast systems would be a beneficial management tool for their communities.

\subsection{References}

Befus, K. M., Barnard, P. L., Hoover, D. J., Finzi Hart, J. A., \& Voss, C. I. (2020). Increasing threat of coastal groundwater hazards from sea-level rise in California. Nature Climate Change, 10, 946-952.

Boufadel, M. C., Xia, Y., \& Li, H. (2011). Modeling solute transport and transient seepage in a laboratory beach under tidal influence. Environmental Modelling \& Software, 26(7), 899912. https://doi.org/10.1016/j.envsoft.2011.02.005

Butt, T. \& Russell, P. (2001). The influence of swash infiltration-exfiltration on beach face sediment transport: onshore or offshore? Coastal Engineering, 42(1), 35-52.

Jalowska, A. M., Spero, T. L., \& Bowden, J. H. (2021). Projecting changes in extreme rainfall from three tropical cyclones using the design-rainfall approach. Npj Climate and Atmospheric Science, 4(1), 23. https://doi.org/10.1038/s41612-021-00176-9

Patricola, C. M., \& Wehner, M. F. (2018). Anthropogenic influences on major tropical cyclone events. Nature, 563, 339-346.

Quick, M. C. (1991). Onshore-offshore sediment transport on beaches. Coastal Engineering, 15(4), 313-332. https://doi.org/10.1016/0378-3839(91)90014-8 
Rotzoll, K., \& Fletcher, C. H. (2013). Assessment of groundwater inundation as a consequence of sea-level rise. Nature Climate Change, 3(5), 477-481.

https://doi.org/10.1038/nclimate1725

Turner, I. L. (1995). Simulating the influence of groundwater seepage on sediment transported by the sweep of the swash zone across macro-tidal beaches. Marine Geology, 125(1-2), 153-174. https://doi.org/10.1016/0025-3227(95)00026-U

Turner, I. L., \& Leatherman, S. P. (1997). Beach dewatering as a "Soft" engineering solution to coastal erosion: A history and critical review. Journal of Coastal Research.

Turner, I. L., \& Masselink, G. (1998). Swash infiltration-exfiltration and sediment transport.

Journal of Geophysical Research: Oceans, 103(C13), 30813-30824. https://doi.org/10.1029/98JC02606

Wilson, A. M., Moore, W. S., Joye, S. B., Anderson, J. L., \& Schutte, C. A. (2011). Stormdriven groundwater flow in a salt marsh. Water Resources Research, 47(2), 2535. https://doi.org/10.1029/2010WR009496

Yang, J., Graf, T., Herold, M., \& Ptak, T. (2013). Modelling the effects of tides and storm surges on coastal aquifers using a coupled surface-subsurface approach. Journal of Contaminant Hydrology, 149, 61-75. https://doi.org/10.1016/j.jconhyd.2013.03.002 


\section{Appendix: Analytical Groundwater Pulse Model}

The spatial and temporal evolutions of the storm-driven groundwater pulse are simulated using the analytical solution (Li et al. 2004):

$$
h(x, t)=-2 A B \int_{-\infty}^{t}\left(\varepsilon-t_{p}\right) \exp \left[-B\left(\varepsilon-t_{p}\right)^{2}\right] \operatorname{erfc}\left[\frac{x}{\sqrt{D(t-\varepsilon)}}\right] d \varepsilon
$$

where $h$ is the groundwater level (m), $x$ is the cross-shore position (m, positive inland from the $\mathrm{x} 0$ well), $t$ is time (d) after the start of the storm (defined as the local minima in head level at $\mathrm{x} 0$

preceding the storm), $A$ is the amplitude of the $\mathrm{x} 0$ fluctuation $(\mathrm{m}), B$ is a time factor $\left(\mathrm{d}^{-2}, \mathrm{~B}^{-1 / 2}\right.$ represents the duration of the elevated water level at $\mathrm{x} 0$ ), $t_{p}$ is the time of the storm peak at $\mathrm{x} 0$ relative to the preceding local minima, and $\mathrm{D}$ is aquifer diffusivity $\left(\mathrm{m}^{2} / \mathrm{d}\right)$. The analytical solution assumes a homogeneous and isotropic aquifer, consistent with the results of the slug tests that were performed across the barrier island. The analytical solution also assumes a shallow aquifer, unidirectional (horizontal) flow, negligible capillary effects, small pulse amplitude relative to aquifer depth, and a vertical beach.

The analytical solution is evaluated by comparison with the observed amplitude $A_{j}$ and time of peak water level $t_{p, j}$ (the local maxima in head after time $t_{0}$, which ranged from 1 to $9 \mathrm{~d}$ ) at inland locations $j$. The observed 36-hr averaged groundwater fluctuation $h_{j}$ at each location is fit using least squares to a pulse function

$$
h_{j}(t)=h_{0_{j}}+A_{j} \exp \left[-B_{j}\left(t-t_{p_{j}}\right)\right]
$$


where $h_{0, j}$ is the pre-storm head level and $A_{j}$ and $B_{\mathrm{j}}$ are the pulse amplitude and time factors, respectively. Only the increasing portion of the groundwater level time series is used in the fit because the temporal asymmetry of the draining relative to the filling of the unconfined aquifer often is not consistent with the Gaussian pulse assumed by the analytical solution (Cartwright and Gibbes, 2011). The resulting squared correlations $\left(\mathrm{R}^{2}\right)$ for the fits are greater than 0.9 for all storms at all locations. Hurricane Matthew is excluded from the pulse propagation analysis because groundwater changes owing to rainfall of $>0.2 \mathrm{~m}$ obscured the groundwater fluctuation driven by the increase in shoreline water level.

To estimate analytically the pulse amplitude and time lag as a function of inland position, Equation (A1) is non-dimensionalized as:

$$
\underline{h}^{*}\left(x^{*}, t^{*}\right)=-2 \int_{-\infty}^{t^{*}} \varepsilon^{*} \exp \left[-\left(\varepsilon^{*}\right)^{2}\right] \operatorname{erfc}\left[\frac{x^{*}}{\sqrt{t^{*}-\varepsilon^{*}}}\right] d \varepsilon^{*}
$$

in which the non-dimensional amplitude attenuation $(\alpha)$, time lag ( $\Delta \phi_{*}$, in days), and cross-shore location $\left(x^{*}\right)$ at inland locations $j$ are computed relative to the $\mathrm{x} 0$ well via given by (Li et al., 2004):

$$
\begin{gathered}
\alpha=\frac{A_{j}}{A} \\
\Delta \phi^{*}=\left(t_{p_{j}}-t_{p}\right) \sqrt{B} \\
x^{*}=\frac{x}{2 \sqrt{D / B^{1 / 2}}}
\end{gathered}
$$


Analytical estimates (Figure 4, solid curves) of the bulge properties ( $\alpha$ and $\Delta \phi_{*}$ ) as a function of inland distance $x^{*}$ are obtained from the magnitude and time of the maximum non-dimensional of the Gaussian pulse at each cross-shore position (Equation (A3)). Observational estimates of the non-dimensional amplitude attenuation, phase lag, and distance (Figure 4, symbols) are estimated from Equations (A4), (A5), and (A6) with $A, A_{j}, t_{p}, t$, and $B_{j}$ determined from the best fits of the measured groundwater levels $h$ to Gaussian curves (Equation (A2)).

The aquifer diffusivity is estimated by determining the value that yields the best fit of the analytical solution (Equation (A1)) to the observed non-dimensional amplitude attenuation and phase lag (Equations (A4) and (A5)) as a function of non-dimensional distance (Equation (A6)) for the 26 storm events without heavy rainfall.

The effects of rainfall are accounted for in the pulse model assuming linear superposition to yield:

$$
h(x, t)=h_{0, j}-2 A B \int_{-\infty}^{t}\left(\varepsilon-t_{p}\right) \exp \left[-B\left(\varepsilon-t_{p}\right)^{2}\right] \operatorname{erfc}\left[\frac{x}{2 \sqrt{D(t-\varepsilon)}}\right] d \varepsilon+\frac{R}{n_{e}}
$$

where the amount of rainfall during the storm $R$ is assumed spatially uniform and $n_{e}$ is the effective porosity estimated from observations.

\section{References:}

Li., L., Cartwright, N., Nielsen, P., \& Lockington, D. (2004). Response of coastal groundwater table to offshore storms. China Ocean Engineering, 18(3), 423-431 